Atmos. Chem. Phys., 13, 4073-4109, 2013

www.atmos-chem-phys.net/13/4073/2013/

doi:10.5194/acp-13-4073-2013

(C) Author(s) 2013. CC Attribution 3.0 License.

\title{
The MACC reanalysis: an 8 yr data set of atmospheric composition
}

\author{
A. Inness ${ }^{1}$, F. Baier ${ }^{2}$, A. Benedetti ${ }^{1}$, I. Bouarar ${ }^{3}$, S. Chabrillat $^{4}$, H. Clark $^{15,16}$, C. Clerbaux $^{3}$, P. Coheur ${ }^{14}$, \\ R. J. Engelen ${ }^{1}$, Q. Errera ${ }^{4}$, J. Flemming ${ }^{1}$, M. George ${ }^{3}$, C. Granier ${ }^{3,6,7}$, J. Hadji-Lazaro ${ }^{3}$, V. Huijnen ${ }^{8}$, D. Hurtmans ${ }^{14}$, \\ L. Jones ${ }^{1}$, J. W. Kaiser ${ }^{1,5,9}$, J. Kapsomenakis ${ }^{12}$, K. Lefever ${ }^{4}$, J. Leitão ${ }^{10}$, M. Razinger ${ }^{1}$, A. Richter ${ }^{10}$, M. G. Schultz ${ }^{11}$, \\ A. J. Simmons ${ }^{1}$, M. Suttie ${ }^{1}$, O. Stein ${ }^{11}$, J.-N. Thépaut ${ }^{1}$, V. Thouret ${ }^{15,16}$, M. Vrekoussis ${ }^{12,13}$, C. Zerefos ${ }^{12}$, and \\ the MACC team \\ ${ }^{1}$ ECMWF, Reading, UK \\ ${ }^{2}$ DLR, Oberpfaffenhofen, Germany \\ ${ }^{3}$ UPMC Univ. Paris 06, Université Versailles St-Quentin, CNRS/INSU, LATMOS-IPSL, Paris, France \\ ${ }^{4}$ BIRA-IASB, Brussels, Belgium \\ ${ }^{5}$ King's College London, London, UK \\ ${ }^{6} \mathrm{NOAA} / \mathrm{ESRL}$ and CIRES, University of Colorado, Boulder, CO, USA \\ ${ }^{7}$ Max Planck Institute for Meteorology, Hamburg, Germany \\ ${ }^{8}$ KNMI, De Bilt, the Netherlands \\ ${ }^{9}$ Max-Planck-Institute for Chemistry, Mainz, Germany \\ ${ }^{10}$ IUP-Bremen, Bremen, Germany \\ ${ }^{11}$ Forschungszentrum Jülich, Jülich, Germany \\ ${ }^{12}$ Research Center for Atmospheric Physics and Climatology, Academy of Athens, Athens, Greece \\ ${ }^{13}$ EEWRC, The Cyprus Institute, Nicosia, Cyprus \\ ${ }^{14}$ Spectroscopie de l'Atmosphère, Service de Chimie Quantique et Photophysique, Université Libre de Bruxelles (ULB), \\ Brussels, Belgium \\ ${ }^{15}$ Université de Toulouse, UPS, LA (Laboratoire d'Aérologie), Toulouse, France \\ ${ }^{16}$ CNRS, LA (Laboratoire d'Aérologie), UMR5560, Toulouse, France
}

Correspondence to: A. Inness (a.inness@ecmwf.int)

Received: 8 October 2012 - Published in Atmos. Chem. Phys. Discuss.: 5 December 2012

Revised: 20 March 2013 - Accepted: 21 March 2013 - Published: 18 April 2013

\begin{abstract}
An eight-year long reanalysis of atmospheric composition data covering the period 2003-2010 was constructed as part of the FP7-funded Monitoring Atmospheric Composition and Climate project by assimilating satellite data into a global model and data assimilation system. This reanalysis provides fields of chemically reactive gases, namely carbon monoxide, ozone, nitrogen oxides, and formaldehyde, as well as aerosols and greenhouse gases globally at a horizontal resolution of about $80 \mathrm{~km}$ for both the troposphere and the stratosphere. This paper describes the assimilation system for the reactive gases and presents validation results for the reactive gas analysis fields to document the data set and to give a first indication of its quality.

Tropospheric $\mathrm{CO}$ values from the MACC reanalysis are on average $10-20 \%$ lower than routine observations from
\end{abstract}

commercial aircrafts over airports through most of the troposphere, and have larger negative biases in the boundary layer at urban sites affected by air pollution, possibly due to an underestimation of $\mathrm{CO}$ or precursor emissions.

Stratospheric ozone fields from the MACC reanalysis agree with ozonesondes and ACE-FTS data to within $\pm 10 \%$ in most seasons and regions. In the troposphere the reanalysis shows biases of $-5 \%$ to $+10 \%$ with respect to ozonesondes and aircraft data in the extratropics, but has larger negative biases in the tropics. Area-averaged total column ozone agrees with ozone fields from a multi-sensor reanalysis data set to within a few percent.

$\mathrm{NO}_{2}$ fields from the reanalysis show the right seasonality over polluted urban areas of the $\mathrm{NH}$ and over tropical biomass burning areas, but underestimate wintertime $\mathrm{NO}_{2}$ 
maxima over anthropogenic pollution regions and overestimate $\mathrm{NO}_{2}$ in northern and southern Africa during the tropical biomass burning seasons.

Tropospheric HCHO is well simulated in the MACC reanalysis even though no satellite data are assimilated. It shows good agreement with independent SCIAMACHY retrievals over regions dominated by biogenic emissions with some anthropogenic input, such as the eastern US and China, and also over African regions influenced by biogenic sources and biomass burning.

\section{Introduction}

Monitoring Atmospheric Composition and Climate (MACC) is a research project with the aim of establishing the core global and regional atmospheric environmental services for the European GMES (Global Monitoring for Environment and Security) initiative. The project was funded from 1 June 2009 to 31 December 2011 under the Seventh Framework Programme of the European Union. MACC built on the predecessor projects Global and regional Earthsystem Monitoring using Satellite and in-situ data (GEMS; Hollingsworth et al., 2008) and PROtocol MOniToring for the GMES Service Element: Atmosphere (PROMOTE; http: //www.gse-promote.org/). The project combined state-ofthe-art atmospheric modelling with earth observation data to provide information services covering European air quality, global atmospheric composition, climate, and UV and solar energy. The global model and data assimilation system used in MACC was based on the European Centre for Medium-Range Weather Forecasts' (ECMWF) Integrated Forecast System (IFS). More information and a history of changes introduced in the IFS since 1985 is available from http://www.ecmwf.int/products/data/operational system/index.html. In GEMS, IFS had been extended to include chemically reactive gases (Flemming et al., 2009; Inness et al., 2009), aerosols (Benedetti et al., 2009; Morcrette et al., 2009) and greenhouse gases (Engelen et al., 2009), so that ECMWF's four-dimensional variational data assimilation (4D-Var) system could be used to assimilate satellite observations of atmospheric composition at global scale. Chemical transport models (CTMs) were coupled to the IFS using the Ocean Atmosphere Sea Ice Soil coupling software (OASIS4; Valcke and Redler, 2006) to provide initial fields and chemical production and loss rates for the reactive gases (Flemming et al., 2009).

MACC generated data records of atmospheric composition for recent years, data for monitoring present conditions, and forecasts of the distribution of key constituents for a few days ahead. As part of MACC an eight-year long reanalysis over the period 2003-2010 of atmospheric composition data was constructed. The MACC reanalysis was built on the experience gained by producing a reanalysis of atmo- spheric composition as part of the GEMS project. MACC used a newer model than the one used in GEMS, and benefited from the assimilation of more and reprocessed satellite data and from having a higher horizontal resolution $(80 \mathrm{~km}$ instead of $125 \mathrm{~km}$ as in GEMS). The period 2003-2010 was chosen based on consideration of the available satellite data of atmospheric composition. Reactive gases were calculated with a system configuration where the CTM Model for OZone And Related chemical Tracers (MOZART-3; Kinnison et al., 2007; Stein et al., 2009) was coupled to the IFS (Stein et al., 2012).

Assimilation of satellite data on atmospheric composition with focus on stratospheric ozone has been carried out for over a decade (Hólm et al., 1999; Khattatov et al., 2000; Dethof and Hólm, 2004; Geer et al., 2006; Arellano et al., 2007; Lahoz et al., 2007; Dragani, 2010, 2011), and global ozone forecasts are now produced routinely by several meteorological centres. ECMWF, for example, produces daily ozone analyses and forecasts, the Koninklijk Nederlands Meteorologisch Instituut (KNMI) uses the TM3-DAM system to produce operational ozone forecasts and analyses (Eskes et al., 2002), and the National Centers for Environmental Prediction (NCEP) assimilate several ozone products into their operational Global Forecast System (http://www.cpc. ncep.noaa.gov/products/stratosphere/strat_a_f/). The Belgian Institute for Space Aeronomy has the Belgian Assimilation System for Chemical Observations (BASCOE, Errera et al., 2008), while the German Aerospace Centre applies the Synoptic Analyses of Chemical constituents by Advanced Data Assimilation (SACADA) model (Elbern et al., 2010). Both $4 \mathrm{D}$-Var systems are dedicated to the assimilation of stratospheric chemical observations making use of explicit chemistry. Data assimilation is now also increasingly being used for other chemical trace gases in both global and regional model systems (Baklanov et al., 2008; Sandu and Chai, 2011; Zhang et al., 2011), and data assimilation code has been implemented in several chemical transport models (e.g. GEOSChem, Henze et al., 2007; Parrington et al., 2008). Assimilation of tropospheric constituents, however, is still in its infancy.

While several centres have produced meteorological reanalyses, for example NCEP (Kalnay et al., 1996), ECMWF (Gibson et al., 1997; Uppala et al., 2005; Dee et al., 2011), the Japan Meteorological Agency (JMA; Onogi et al., 2007) and the Global Modeling and Assimilation Office (Schubert et al., 1993), there has been less activity with respect to reanalyses of atmospheric composition. ECMWF included the assimilation of ozone data in several of its reanalysis projects, and reanalysed ozone fields are available from ERA-40 (Dethof and Hólm, 2004) and ERA-Interim (Dragani, 2010, 2011). At KNMI a 30 yr long ozone data set was produced from a multi-sensor reanalysis (Van der A et al., 2010).

MACC was in a position to combine a wealth of atmospheric composition data with a numerical model and data 
assimilation system to produce a reanalysis of atmospheric composition. This paper describes the setup of the reactive gas data assimilation system used in the MACC reanalysis of atmospheric composition. The reactive gases that were included as IFS model variables in the MACC reanalysis were ozone $\left(\mathrm{O}_{3}\right)$, carbon monoxide $(\mathrm{CO})$, nitrogen oxides $\left(\mathrm{NO}_{\mathrm{x}}=\mathrm{NO}+\mathrm{NO}_{2}\right)$, and formaldehyde $(\mathrm{HCHO})$. These four gases were chosen because they play a key role in the chemistry of the atmosphere and have been measured by spaceborne instruments with sufficient density and continuity to deliver strongly constrained analyses.

Carbon monoxide has natural and anthropogenic sources (Seinfeld and Pandis, 2006; Kanakidou and Crutzen, 1999). It is emitted from the soil, plants and the ocean, but its main sources are incomplete fossil fuel and biomass burning, which lead to enhanced surface concentrations. Another important source of $\mathrm{CO}$ is the oxidation of anthropogenic and biogenic volatile organic compounds (VOCs). In areas with large biogenic emissions (e.g. tropical rain forests), oxidation of biogenic VOCs contributes strongly to the production of CO (Griffin et al., 2007). Hudman et al. (2008) found that over the eastern US during summer the biogenic sources of $\mathrm{CO}$ were higher than the anthropogenic ones due to decreasing anthropogenic emissions. The highest $\mathrm{CO}$ concentrations are found over the industrial regions of Europe, Asia and North America (see Fig. 3 below). Surface concentrations are higher during the winter than during the summer months because of the shorter lifetime in the summer due to higher hydroxyl radical $(\mathrm{OH})$ concentrations and more intense mixing processes. Tropical biomass burning is most intense during the dry season (December-April in the Northern Hemisphere $(\mathrm{NH})$ tropics, July-October in the Southern Hemisphere (SH) tropics). CO has a lifetime of several weeks and can serve as a tracer for regional and intercontinental transport of polluted air. The main loss process is the reaction with the $\mathrm{OH}$ radical.

Ozone is an important species for chemistry of the troposphere. Tropospheric ozone is a regional-scale pollutant and at high concentrations near the surface harmful to human health. Photolysis of ozone, followed by reaction with water vapour, provides the primary source of the hydroxyl radical. Ozone is also a significant greenhouse gas, particularly in the upper troposphere (Hansen et al., 1997). The majority of tropospheric ozone formation occurs when $\mathrm{NO}_{\mathrm{x}}$, $\mathrm{CO}$, and VOCs react in the atmosphere in the presence of sunlight. In urban areas in the $\mathrm{NH}$, high ozone levels usually occur during spring and summer. About $90 \%$ of the total ozone amount resides in the stratosphere, a result of oxygen photolysis (Chapman, 1930) and other catalytic cycles (e.g. review in Solomon, 1999). This ozone layer absorbs a large part of the sun's harmful UV radiation. Anthropogenic chlorofluorocarbons led to a global decrease of the ozone total column, but thanks to the Montreal Protocol the ozone layer is expected to recover in the next decades (Newman et al., 2009; WMO, 2011; Zerefos et al., 2012). Over Antarctica ozone destruction during Austral spring still leads to strong and rapid depletion of the ozone layer ("ozone hole"). Stratospheric ozone destruction happens also on a smaller scale over the Arctic in Boreal spring (Manney et al., 2011).

Nitrogen oxides play a key role in tropospheric chemistry and are the main ingredient in the formation of ground-level ozone. Their sources are anthropogenic emissions, biomass burning, soil emissions and, at altitude, lightning and aviation. $\mathrm{NO}_{\mathrm{x}}$ has a lifetime of a few days in the free troposphere and less in the boundary layer, so that concentrations are larger over land than over the oceans. The largest concentrations are found over industrial and urban regions of the eastern US, California, Europe, China and Japan (see Fig. 23 below). Loss processes for $\mathrm{NO}_{\mathrm{x}}$ are the formation reactions of $\mathrm{OH}$ to $\mathrm{HNO}_{3}$, with $\mathrm{O}_{3}$ to $\mathrm{NO}_{3}$ at night, and formation of peroxyacyl nitrates as well as dry deposition.

Formaldehyde is one of the most abundant hydrocarbons in the atmosphere. Even though its primary emission sources are industrial activities, fossil fuel burning, and biomass burning, the largest contribution to the $\mathrm{HCHO}$ budget is its secondary source from the oxidation of VOCs, in particular isoprene (Atkinson, 1994; Abbot et al., 2003; Palmer et al., 2003, 2006; Millet et al., 2008). The main source of HCHO in the background troposphere is the oxidation of methane, which accounts for more than half of the global HCHO production (Stavrakou et al., 2009). In the continental boundary layer, the oxidation of non-methane VOCs dominates. The main sinks of $\mathrm{HCHO}$ are photolysis and oxidation by $\mathrm{OH}$. $\mathrm{HCHO}$ has a short lifetime of a few hours, making it a good indicator of hydrocarbon emission areas. While the data quality of the individual satellite retrievals of $\mathrm{HCHO}$ was not sufficient to allow active assimilation in the MACC reanalysis, passive monitoring was performed by the assimilation system.

In this paper we describe results for the fields of $\mathrm{CO}, \mathrm{O}_{3}$, $\mathrm{NO}_{\mathrm{x}}$ and $\mathrm{HCHO}$. The paper is structured in the following way: Sect. 2 describes the coupled IFS global reactive gas (GRG) system and the data assimilation setup for the reactive gases. This includes information about the data assimilation system, aspects of the coupling between the IFS and the CTM, and information about satellite and emission data that were used in the reanalysis. Section 3 shows results from the reanalysis and comparisons with independent observations, and Sect. 4 presents the conclusions.

\section{Description of the MACC chemical data assimilation system}

\subsection{Model system}

The MACC data assimilation system for chemically reactive gases was constructed by extending ECMWF's IFS to include fields for $\mathrm{O}_{3}, \mathrm{CO}, \mathrm{NO}_{\mathrm{x}}$, and $\mathrm{HCHO}$. Source and sink terms for these gases are supplied by a CTM that is 
coupled to the IFS using the OASIS4 coupler (Valcke and Redler, 2006). The CTM holds a detailed representation of the atmospheric chemical system together with its sources and sinks. For the MACC reanalysis the MOZART-3 CTM (115 species) which features a comprehensive description of stratospheric and tropospheric chemical processes was coupled to the IFS. A description of the MOZART-3 CTM as implemented in the MACC system can be found in Stein (2009 and 2012). In the coupled setup the IFS and the CTM run in parallel, exchanging fields through the OASIS4 coupler every hour (Flemming et al., 2009). This means the IFS supplies the meteorological data and updated mixing ratios for the MACC GRG species $\mathrm{O}_{3}, \mathrm{CO}, \mathrm{NO}_{\mathrm{x}}$, and $\mathrm{HCHO}$ to the CTM, and the CTM provides IFS with initial conditions for the four GRG species and with chemical tendency fields every hour. These are tendencies due to chemistry, wet deposition and atmospheric emissions, and tendencies due to surface fluxes (emission, dry deposition). The tendencies for the individual species are combined before the exchange and one total tendency per species is given from the CTM to the IFS. The time step is 1800s for the IFS and 900s for the CTM.

The IFS is a spectral model and the global fields of the MACC reanalysis are archived at T255 spectral truncation, corresponding to a reduced Gaussian grid (Hortal and Simmons, 1991) of about $80 \mathrm{~km}$ horizontal resolution. The vertical coordinate system is given by 60 hybrid sigma-pressure levels, with a model top at $0.1 \mathrm{hPa}$. In order to avoid difficulties in the vertical interpolation by the OASIS4 coupler, the CTMs use the same 60 vertical levels. The coupler only has to perform horizontal interpolations for which the bi-linear mode is applied. The MOZART-3 resolution is $1.125^{\circ} \times 1.125^{\circ}$, lower than the IFS resolution, because of the high computational cost of the CTM that would make a multi-year run unfeasible at higher resolution. The IFS is run on a higher horizontal resolution than the CTM as this improves the quality of the meteorological forecasts and because a lower resolution would limit the acceptance of high resolution observations within the data assimilation. More details of the CTMs and the coupling setup are given in Flemming et al. (2009). A modification of MOZART-3 as described in Kinnison et al. (2007) was used in the MACC reanalysis from 2003-2008 (version 3.1). From 1 January 2009 onwards, MOZART version 3.5 was used in the MACC reanalysis, and this implementation is described in Stein et al. (2012). The updated version has a better representation of ozone depletion inside the Antarctic vortex (Flemming et al., 2011b).

Ozone has been included in the IFS as an additional model variable, and ozone data have been assimilated at ECMWF since 1999 (Hólm et al., 1999; Dethof and Hólm, 2004). However, the ECMWF approach differs from the MACC approach because it uses a built-in chemistry routine with a parameterization of photochemical sources and sinks based on Cariolle and Teyssèdre (2007), instead of a coupled CTM to provide the chemical tendencies. Moreover, this relatively simple chemical scheme is only suited for the description of stratospheric ozone, while the MOZART-3 CTM represents the whole tropospheric and stratospheric chemistry.

\subsection{Data assimilation}

ECMWF has used an incremental formulation of 4dimensional variational data assimilation since 1997. In 4DVar a cost function is minimized to combine the model background and the observations to obtain the best possible forecast by adjusting the initial conditions. In its incremental formulation (Courtier et al., 1994), 4D-Var can be written as

$$
J(\delta \boldsymbol{x})=\frac{1}{2} \delta \boldsymbol{x}^{T} \mathbf{B}^{-1} \delta \boldsymbol{x}+\frac{1}{2}(\mathbf{H} \delta \boldsymbol{x}-\boldsymbol{d})^{T} \mathbf{R}^{-1}(\mathbf{H} \delta \boldsymbol{x}-\boldsymbol{d}),
$$

where $\delta \boldsymbol{x}$ is the increment, B the background error covariance matrix, $\mathbf{R}$ the observation error covariance matrix (comprising of observational and representativeness errors), and $\mathbf{H}$ a linear approximation of the observation operator. $\boldsymbol{d}=$ $\boldsymbol{y}-\mathbf{H} \boldsymbol{x}_{b}$ is the innovation vector, $\boldsymbol{y}$ the observation vector and $\boldsymbol{x}_{b}$ the background.

The GRG species are integrated into the ECMWF variational analysis as additional model variables. They are minimized together with the other ECMWF fields, which means they can, in principle, influence the analysis of wind and other meteorological variables in 4D-Var. However, given the uncertainty of the GRG observations and the lack of observational constraints of variables such as wind or temperature in the stratosphere and mesosphere, a possible influence of the GRG observations on the meteorological fields was suppressed in the reanalysis. Nevertheless, this might be a worthwhile interaction to study in the future (Semane et al., 2009).

\subsubsection{Observation operators for reactive gases}

Observation operators are needed to calculate the model equivalent of the assimilated observations, i.e. of the satellite retrievals of atmospheric composition. The observations used in the IFS are total or partial column data, i.e. integrated layers bounded by a top and a bottom pressure. The model's background column value is calculated as a simple vertical integral between the top and the bottom pressure given by the partial or total column, at the time and location of the observation.

It is also possible to use averaging kernel information in the observation operator. This removes the impact of the retrieval a priori profile in the assimilation (Eskes and Boersma, 2003). Equation (2) shows how the retrieved quantity $\hat{\boldsymbol{x}}_{\mathrm{r}}$ can be described as a linear combination of the a priori profile $\boldsymbol{x}_{\mathrm{a}}$ and the true profile $\boldsymbol{x}_{\mathrm{t}}$ by using the averaging kernel matrix A (Deeter et al., 2009). The averaging kernels come about due to the optimal estimation approach to retrieving data from the satellite measurements and indicate the sensitivity of the retrieved profile to the true profile, with the remainder of the information coming from the a priori profile 
(Rodgers, 2000; Emmons et al., 2004, 2007). Where the averaging kernel matrix elements are small, the retrieved profile shows little sensitivity to changes in the true profile and the retrieved quantity is largely determined by the a priori.

$\hat{\boldsymbol{x}}_{\mathrm{r}} \approx \boldsymbol{x}_{\mathrm{a}}+\mathbf{A}\left(\boldsymbol{x}_{\mathrm{t}}-\boldsymbol{x}_{\mathrm{a}}\right)$

Equation (2) can be used in the observation operator to transform the model field to have the same vertical resolution and a priori dependence as the satellite retrievals. Thus, the difference between the retrieved quantity $\hat{\boldsymbol{x}}_{\mathrm{r}}$ and its model equivalent $\hat{\boldsymbol{x}}_{\mathrm{m}}$ can be given as

$\hat{\boldsymbol{x}}_{\mathrm{r}}-\hat{\boldsymbol{x}}_{\mathrm{m}}=\mathbf{A}\left(\boldsymbol{x}_{\mathrm{t}}-\boldsymbol{x}_{\mathrm{m}}\right)$.

This means that the model field and the retrieved quantity can be compared in a way that is not affected by the a priori profile dependence or by different vertical resolutions. Averaging kernels were used in the MACC reanalysis if they were provided by the data producers (more details will be given in Sect. 2.3).

A special observation operator is used for the assimilation of $\mathrm{NO}_{2}$ data. The fast diurnal $\mathrm{NO}_{2}-\mathrm{NO}$ interconversion caused by solar radiation can not be handled by the coupled model with an exchange frequency for the chemical tendencies of one hour, and the absence of a full chemistry module in the IFS prevents direct assimilation of short-lived chemical species. Therefore, $\mathrm{NO}_{\mathrm{x}}$ is used as the IFS model variable instead of $\mathrm{NO}_{2}$. Its longer photochemical lifetime allows both a better simulation by the coupled forward model and a correct assimilation in the adjoint model. The use of $\mathrm{NO}_{\mathrm{x}}$ also reduces spatial variability everywhere, which is of advantage for the data assimilation. Since the satellite observations assimilated in the MACC system are $\mathrm{NO}_{2}$ data, a diagnostic $\mathrm{NO}_{2} / \mathrm{NO}_{\mathrm{x}}$ interconversion operator was developed, including its tangent linear and adjoint. This operator is based on a simple photochemical equilibrium between the $\mathrm{NO}_{2}$ photolysis rate $\left(\mathrm{JNO}_{2}\right)$ and the ozone mixing ratio:

$$
\frac{\left[\mathrm{NO}_{2}\right]}{\left[\mathrm{NO}_{\mathrm{x}}\right]} \approx \frac{k\left[\mathrm{O}_{3 \mathrm{eff}}\right]}{J \mathrm{NO}_{2}+k\left[\mathrm{O}_{3 \mathrm{eff}}\right]} .
$$

Here, $k$ is the rate coefficient of the reaction $\mathrm{O}_{3}+\mathrm{NO} \rightarrow$ $\mathrm{NO}_{2}+\mathrm{O}_{2}$ and depends on temperature, while $\mathrm{JNO}_{2}$ depends on surface albedo, solar flux, solar zenith angle, overhead ozone column, cloud optical properties and temperature. A parameterized approach for the calculation of $J \mathrm{NO}_{2}$ was used based on the band scheme by Landgraf and Crutzen (1998) in combination with actinic fluxes parameterized following Krol and Van Weele (1997). In the stratosphere $\mathrm{O}_{3}$ eff is equal to $\mathrm{O}_{3}$, but in the troposphere it is equal to

$\left[\mathrm{O}_{3}\right.$ eff $]=\left[\mathrm{O}_{3}\right]+\left[\mathrm{XO}_{2}\right] \cos \alpha$

to account for the influence of per-oxy-radicals $\left(\mathrm{XO}_{2}=\right.$ $\mathrm{HO}_{2}+\mathrm{RO}_{2}$ ). In an ad hoc approach, a per-oxy-radical concentration of $80 \mathrm{ppt}$ in the troposphere was assumed (Kleinman et al., 1995), which was scaled by the cosine of the solar zenith angle $\alpha$ to account for the diurnal cycle of the per-oxy-radical concentration. This improved the match of the $\mathrm{NO}_{2} / \mathrm{NO}_{\mathrm{x}}$ ratios from the operator and the MOZART-3 fields (Flemming et al., 2011a).

\subsubsection{Observation errors for the reactive gases}

The observation error and background error covariance matrices determine the relative weight given to the observation and the background in the analysis (see Eq. (1)). For the reactive gases, observation errors given by the data providers were used. If these values were below $5 \%$, a minimum value of $5 \%$ was taken. The observation error was assumed to include any observation operator error and a representativeness error that could arise because of differences in resolution of observation and the model, and that accounts for scales unresolved by the model. The satellite data were thinned in the data pre-processing to ensure a minimum distance between two observations from the same platform. This was done to reduce the data volume and helped to avoid redundant observations that did not contain any independent information. It also avoided the introduction of spatial observation error correlation that was not accounted for in the data assimilation algorithm. In the MACC reanalysis, the reactive gas satellite retrievals were thinned to a horizontal resolution of $1^{\circ} \times 1^{\circ}$ by randomly selecting an observation in the grid box.

Variational quality control (Andersson and Järvinen, 1999) and background quality checks were applied to the reactive gas observations. In the background quality check, the square of the normalized background departure was considered as suspect when it exceeded its expected variance by more than a predefined multiple, i.e. 5 for most variables. In this case the observation was not used in the analysis.

\subsubsection{Background errors for the reactive gases}

In the ECMWF data assimilation system, the background error covariance matrix is given in a wavelet formulation (Fisher, 2004, 2006). This allows both spatial and spectral variations of the horizontal and vertical background error covariances. The background error standard deviations determine the relative weight of the background in the analysis, while the correlations determine how the analysis increments are spread in the horizontal and in the vertical. This is particularly important for vertically integrated observations, such as total column trace gas retrievals. In this case the vertical structure of the increments is determined by the vertical correlations of the background errors since the observations do not give information about this distribution.

The background error correlations used in the operational ECMWF data assimilation system were derived from an ensemble of forecast differences, using a method proposed by Fisher and Andersson (2001). This ensemble consisted of ten members, all run for one month. For the MACC ozone field, the same background error statistics used in 
Table 1. Satellite retrievals of reactive gases that were actively assimilated in the MACC reanalysis. PROF denotes profile data, TC total columns, TRC tropospheric columns, PC partial columns, and SOE solar elevation. PC SBUV/2 data consist of 6 layers between the surface and $0.1 \mathrm{hPa}$. NRT (near-real-time) data are available within a few hours after the observation was made, and are being used in operational forecast systems. For periods towards the end of the MACC reanalysis period, NRT data were used for some of the species when no offline products were available.

\begin{tabular}{|c|c|c|c|c|c|c|c|}
\hline Sensor & Satellite & Provider & Version & Period & Type & $\begin{array}{l}\text { Data usage } \\
\text { criteria }\end{array}$ & Reference \\
\hline GOME & ERS-2 & RAL & & $20030101-20030531$ & $\mathrm{O}_{3} \mathrm{PROF}$ & $\begin{array}{l}\text { Used if SOE }>15^{\circ} \text { and } \\
80^{\circ} \mathrm{S}<\text { lat }<80^{\circ} \mathrm{N}\end{array}$ & Siddans et al. (2007) \\
\hline MIPAS & ENVISAT & ESA & & $20030127-20040326$ & $\mathrm{O}_{3} \mathrm{PROF}$ & All data used & Carli et al. (2004) \\
\hline MLS & AURA & NASA & V02 & $\begin{array}{l}\text { 20040808-20090315, } \\
\text { NRT data from } \\
20090316\end{array}$ & $\mathrm{O}_{3} \mathrm{PROF}$ & All data used & Waters et al. (2006) \\
\hline OMI & AURA & NASA & V003 & $\begin{array}{l}\text { From 20041001, } \\
\text { NRT data } \\
\text { 20070321-20071231 }\end{array}$ & $\mathrm{O}_{3} \mathrm{TC}$ & Used if SOE $>10^{\circ}$ & $\begin{array}{l}\text { Bhartia and Welle- } \\
\text { meyer (2002); } \\
\text { Levelt et al. (2006) }\end{array}$ \\
\hline SBUV/2 & NOAA-16 & NOAA & V8 & From 20040101 & $\mathrm{O}_{3} \mathrm{PC}$ & Used if $\mathrm{SOE}>6^{\circ}$ & Bhartia et al. (1996) \\
\hline SBUV/2 & NOAA-17 & NOAA & V8 & From 20030101 & $\mathrm{O}_{3} \mathrm{PC}$ & Used if $\mathrm{SOE}>6^{\circ}$ & Bhartia et al. (1996) \\
\hline SBUV/2 & NOAA-18 & NOAA & V8 & From 20050604 & $\mathrm{O}_{3} \mathrm{PC}$ & Used if $\mathrm{SOE}>6^{\circ}$ & Bhartia et al. (1996) \\
\hline SCIAMACHY & ENVISAT & KNMI & & From 20030101 & $\mathrm{O}_{3} \mathrm{TC}$ & Used if $\mathrm{SOE}>6^{\circ}$ & Eskes et al. (2005) \\
\hline IASI & METOP-A & LATMOS/ULB & & From 20080401 & $\mathrm{CO} \mathrm{TC}$ & Used if $70^{\circ} \mathrm{S}<$ lat $<70^{\circ} \mathrm{N}$ & $\begin{array}{l}\text { George et al. (2009); } \\
\text { Clerbaux et al. (2009) }\end{array}$ \\
\hline MOPITT & TERRA & NCAR & V4 & $\begin{array}{l}\text { From 20030101, NRT } \\
\text { data after } 20100323\end{array}$ & $\mathrm{CO} \mathrm{TC}$ & Used if $65^{\circ} \mathrm{S}<$ lat $<65^{\circ} \mathrm{N}$ & Deeter et al. (2010) \\
\hline SCIAMACHY & ENVISAT & KNMI & V1.04 & $20030101-20070630$ & $\mathrm{NO}_{2}$ TRC & $\begin{array}{l}\text { Used if SOE }>6^{\circ} \text { and } \\
60^{\circ} \mathrm{S}<\text { lat }<60^{\circ} \mathrm{N}\end{array}$ & Boersma et al. (2004) \\
\hline SCIAMACHY & ENVISAT & KNMI & V1.1 & From 20070911 & $\mathrm{NO}_{2} \mathrm{TRC}$ & $\begin{array}{l}\text { Used if SOE }>6^{\circ} \text { and } \\
60^{\circ} \mathrm{S}<\text { lat }<60^{\circ} \mathrm{N}\end{array}$ & $\begin{array}{l}\text { http://www.temis.nl; } \\
\text { Wang et al. (2008) }\end{array}$ \\
\hline
\end{tabular}

ECMWF's operational ozone assimilation were used. A different method had to be chosen to determine background error statistics for the other GRG fields because they had not been included in the ensemble of forecast runs. The National Meteorological Center (NMC) method (Parrish and Derber, 1992) was used to derive initial background error statistics for the reactive gases. For this, 150 days of 2-day forecasts were run with the coupled system initialized from fields produced by the free-running MOZART-3 CTM, and the differences between 24-h and 48-h forecasts valid at the same time were used as a proxy for the background errors. These differences were then used to construct a wavelet background error covariance matrix according to the method described by Fisher $(2004,2006)$. This background error covariance matrix contains the statistics for the reactive gases as well as the original statistics for the other meteorological fields. Background errors determined with the NMC method usually have longer horizontal and vertical correlations than those calculated with the analysis ensemble method (Fisher and Andersson, 2001).

For the assimilation of $\mathrm{NO}_{\mathrm{x}}$ data, it was found that the analysis based on mixing ratio was prone to large extrapolation errors, due to the large range of $\mathrm{NO}_{\mathrm{x}}$ mixing ratios which make it difficult to model the background error covariances. Therefore, a logarithmic control variable was developed for $\mathrm{NO}_{\mathrm{x}}$.

The GRG background errors are univariate in order to minimize the feedback effects of the GRG fields on the other variables. Examples of the GRG background error standard deviation profiles and correlations used in the MACC reanalysis can be found in Inness et al. (2009).

\subsection{Satellite data}

\subsubsection{Satellite data used in the reanalysis}

Table 1 lists the data sets that are actively assimilated in the MACC reanalysis to constrain the reactive gases. These contain profile (PROF), total column (TC), partial column (PC) and tropospheric column (TRC) data. The usage criteria for the data sets are also given in the table. In addition to the listed criteria, data were not used if quality flags given by the data producers mark the data as bad quality. $\mathrm{HCHO}$ data were not assimilated in the MACC reanalysis because the data quality of individual satellite retrievals was not sufficient, but analysis fields are available. Monthly mean HCHO observations generally have a total error of $20-40 \%$, but individual observations can have large errors (greater than $50 \%$ for individual pixels of the SCanning Imaging Absorption spectroMeter for Atmospheric CHartographY (SCIAMACHY) or Global Ozone Monitoring Experiment (GOME) instruments; De Smedt et al., 2008), which did not favour assimilating individual observations. Hence, the HCHO reanalysis fields were entirely determined by the MOZART- 3 chemistry, the MACCity and biomass burning emissions (see Sect. 2.4 below), and the atmospheric transport. 

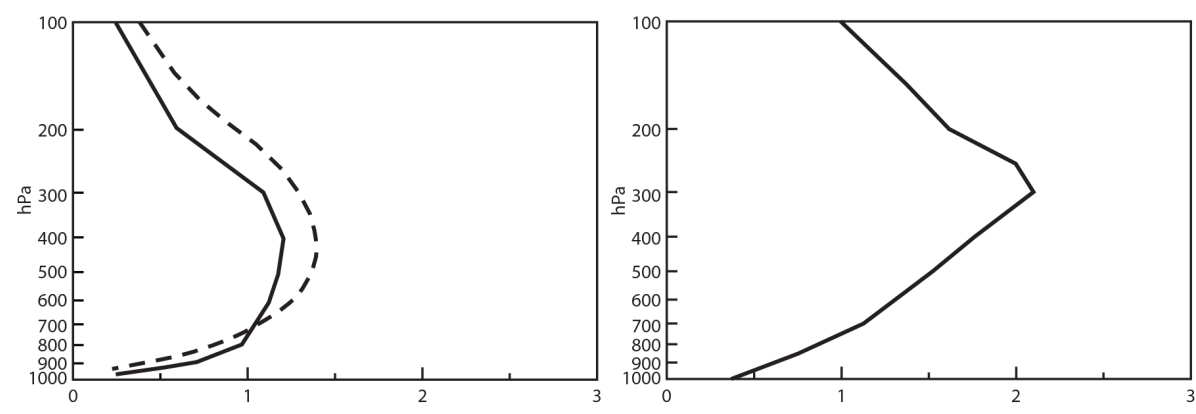

Fig. 1. Left panel: mean averaging kernels for MOPITT (solid) and IASI (dashed) daytime total column CO retrievals for July 2009 averaged over a $5^{\circ} \times 25^{\circ}$ box over Europe $\left(46-51^{\circ} \mathrm{N}, 3-28^{\circ} \mathrm{E}\right)$. Right panel: global mean averaging kernels for tropospheric column $\mathrm{NO}_{2}$ from SCIAMACHY averaged over the period June 2009 to May 2010.

Averaging kernels were used in the observation operators if they were provided by the data producers. This was the case for CO data from the Measurements of Pollution in The Troposphere (MOPITT) instrument and from the Infrared Atmospheric Sounding Interferometer (IASI) and $\mathrm{NO}_{2}$ data from SCIAMACHY. Figure 1 shows averaging kernels from MOPITT CO and IASI CO daytime total column retrievals averaged over a $5^{\circ} \times 25^{\circ}$ box over Europe in July 2009, and global mean averaging kernels for SCIAMACHY $\mathrm{NO}_{2}$ averaged over the period June 2009 to May 2010. MOPITT and IASI have the main sensitivity to $\mathrm{CO}$ in the mid-troposphere, i.e. between 300-700 $\mathrm{hPa}$. SCIAMACHY has broad averaging kernels for $\mathrm{NO}_{2}$, indicating some sensitivity to all tropospheric levels. The global mean profile peaks at $300 \mathrm{hPa}$. Even though the main sensitivity is to $\mathrm{NO}_{2}$ above $700 \mathrm{hPa}$, as the vertical profile of $\mathrm{NO}_{2}$ in polluted regions is dominated by the lowest layers, the retrieved column (which is the product of $\mathrm{NO}_{2}$ profile times averaging kernel) is mainly determined by $\mathrm{NO}_{2}$ in the boundary layer, at least for cloud free situations. The sensitivity at higher altitudes is larger, but as a result of the low $\mathrm{NO}_{2}$ concentrations usually found there, this has only a small effect on the $\mathrm{NO}_{2}$ columns retrieved from satellite data.

\subsubsection{Bias correction and quality control for the reactive gas satellite data}

Retrievals of the same parameter from different satellite instruments can have biases with respect to each other or to the model. Assimilating biased data violates one of the underlying assumptions of data assimilation, namely that the data should be unbiased, and therefore a bias correction scheme has to be applied to the data. Without this, the assimilation would either have to be limited to one retrieval product for a reactive gas, or data would be used that are inconsistent with each other or with the reactive gas forecast. In the MACC reanalysis, the variational bias correction scheme (VarBC) developed at ECMWF for radiance data (Dee, 2004; McNally et al., 2006; Auligné et al., 2007; Dee and Uppala, 2009) was extended to data of atmospheric composition. Bi- ases in the variational scheme are estimated during the analysis by including bias parameters in the control vector. The bias corrections are continuously adjusted to optimize the consistency with all information used in the analysis. Extending VarBC to atmospheric composition data has the advantage that it can be easily applied to a variety of sensors and species.

For the reactive gases in the MACC reanalysis, a start from zero bias was used at the beginning of the experiment. The reanalysis was started on 1 December 2002, so that a monthlong spin-up of the bias correction and the fields was possible. For the assimilation of ozone retrievals, solar elevation and a global constant were used as bias predictors, and data from Solar Backscatter Ultraviolet (SBUV/2) instruments (from various National Oceanic and Atmospheric Administration (NOAA) platforms) and Microwave Limb Sounder (MLS) ozone profiles from 1 January 2008 onwards were used as anchors for the bias correction, i.e. no bias correction was applied to these data. Using anchors for the bias correction should help to avoid drifts in the system. The reason for choosing SBUV/2 data as anchor was that the data were available for the whole reanalysis period, they had been reprocessed and intercalibrated and should hence make a good anchor for the other ozone data sets. While experience at ECMWF had shown this to work well when total column ozone data were assimilated, it was found in the MACC reanalysis that SBUV/2 ozone data (whose lowest layer is between $16 \mathrm{hPa}$ and the surface) could not stop the bias correction drifting for individual MLS layers that have a finer vertical resolution. This drift did not affect the total ozone column much, but it became noticeable in the troposphere and above $15 \mathrm{hPa}$ after a few years (see Sect. 3.2 below). Once the cause of the apparent ozone trend had been identified, it was decided to stop bias correcting MLS data, and from 1 January 2008 onwards, both MLS and SBUV/2 data were used as anchors, i.e. assimilated without bias correction. For the assimilation of $\mathrm{CO}$ retrievals, a globally constant predictor was used for IASI data while MOPITT CO retrievals were used as an anchor. The latter was used as the anchor 
simply because these data were available from the beginning of the reanalysis, not because their data quality was assumed to be better than that of the IASI data. No bias correction was applied to $\mathrm{NO}_{2}$ data, because retrievals from only one instrument (SCIAMACHY) were assimilated.

\subsection{Emissions}

For the MACC reanalysis an updated data set of anthropogenic emissions (MACCity) was produced (Granier et al., 2011a). The emissions are injected into the surface layer in the CTM, which is about $10 \mathrm{~m}$ thick, and quickly distributed throughout the boundary layer by model processes such as convection and vertical diffusion. The anthropogenic emissions for MACCity were developed as an extension of the historical Atmospheric Chemistry and Climate Model Intercomparison Project (ACCMIP) emissions data set (Lamarque et al., 2010) developed for the Intergovernmental Panel on Climate Change Fifth Assessment Report. The ACCMIP data set provides decadal emissions up to the year 2000 . The 2000-2011 MACCity emissions were obtained by using the 2005 and 2010 emissions from the future scenarios called Representative Concentration Pathways (RCPs; Moss et al., 2010). For the MACCity emissions, scenario RCP 8.5 was chosen, since it includes information on regional emissions after 2000 (Van Vuuren et al., 2010; Riahi et al., 2011); a linear interpolation was then applied to obtain the yearly MACCity emissions. Ship emissions are based on Eyring et al. (2010), and a source-specific seasonality developed for the REanalysis of the TROpospheric chemical composition (RETRO) project (http://retro.enes.org/) was applied to the emissions. Monthly average emissions were derived using the seasonal patterns developed within the RETRO project.

Biomass burning emission for the MACC reanalysis for the years 2003-2008 were generated from a preliminary version (v3.0) of the Global Fire Emissions Database (GFED, van der Werf et al., 2010) and fire radiative power (FRP) observations by the Moderate Resolution Imaging Spectroradiometer (MODIS) satellite instruments (Justice et al., 2002). The Global Fire Assimilation System (GFAS) of MACC was used to create daily gridded FRP maps, with which the monthly GFED emissions were redistributed amongst the days of each month (Kaiser et al., 2011). Thus, the monthly budgets of GFEDv3.0 were maintained. In Central and South America, the carbon combustion rate is about $8 \%$ larger in GFEDv3.0 than in the final, published GFEDv3.1 data set. In all other regions, it is smaller. The global average is smaller by $9 \%$. The carbon combustion rate in GFEDv3.1 is in turn smaller than in GFEDv2 (van der Werf et al., 2006) in all regions but boreal North America, Australia and the Middle East; the global average is reduced by $13 \%$.

For the years 2009 and 2010, daily biomass burning emissions from MACC's GFAS, version 1.0 (Kaiser et al., 2012), were used. These are based on MODIS FRP observations, have a horizontal resolution of $0.5 \times 0.5$ degrees and are now available from 2003 onwards, but were not available when the reanalysis was started. The global average carbon combustion rate is $8 \%$ larger than in GFEDv3.1 and thus about $18 \%$ larger than during the first $5 \mathrm{yr}$ of the reanalysis. (Due to slightly modified emission factors and burning patterns, the carbon monoxide emissions are only about $6 \%$ larger than in GFEDv3.1, though.) Overall, the GFAS version 1.0 emissions are approximately $20 \%$ larger than the data used prior to 2009 .

The emission factors for GFEDv3.0 are calculated using an update of the fire-type-dependent emission factors compiled by Andreae and Merlet (2001) and the actual values are listed in van der Werf et al. (2010). An analogous dependency on Andreae and Merlet (2001) holds for GFAS. Its actual emission factors are listed in Kaiser et. al. (2012). In both cases the most significant update is the inclusion of emission factors for peat burning based on Christian et al. (2003). The $\mathrm{NO}_{\mathrm{x}}$ emission factor is expressed as the equivalent amount of NO. For savannah fires, its value has been revised downwards from $3.9 \mathrm{~g}(\mathrm{NO}) / \mathrm{kg}$ (dry matter) to $2.1 \mathrm{~g}(\mathrm{NO}) / \mathrm{kg}$ (dry matter). The $\mathrm{NO}_{\mathrm{x}} / \mathrm{CO}$ emission ratios calculated for the different fire types from the emission factors used in GFEDv3.0 and GFAS range from 0.005 for peat fires in GFAS to 0.035 for savannah fires in both GFAS and GFED3.

Biogenic emissions in the MOZART-3 CTM came from a recent update (Barkley, 2010) of the Model of Emissions of Gases and Aerosols from Nature version 2 (MEGAN2; Guenther et al., 2006, http://acd.ucar. edu/ guenther/MEGAN/MEGAN.htm) and were used in MOZART-3 as monthly surface flux fields without interannual variation. These data were for 2003 and have no interannual variability. The biogenic sources are in particular sensitive to temperature, and there might be inconsistencies between those of the MACC model and of the Goddard Earth Observing System used to generate the biogenic emissions. However, this effect is expected to be small. MOZART- 3 also included several other natural emissions like $\mathrm{NO}_{\mathrm{x}}$ from soils and oceanic emissions from various sources, including the Present and future surface emissions of atmospheric compounds (POET) inventory (Granier et al., 2005, available from the Emissions of Atmospheric Compounds and Compilation of Ancillary Data (ECCAD) database, http://eccad. sedoo.fr/), and accounted for in situ production of $\mathrm{NO}_{\mathrm{x}}$ by lightning.

After the MACC reanalysis had been started, it became apparent that using the MACCity emissions led to an underestimation of $\mathrm{CO}$ concentrations in the Northern Hemisphere compared to independent observations (Granier et al., 2011b; see also Sect. 3.1 below). This could be due to an underestimation of surface emissions, to an underestimation of the chemical production of $\mathrm{CO}$ from the oxidation of VOCs, or to some missing reaction in the CTM. It should be noted that low $\mathrm{CO}$ values are found by most of the CTMs regardless of the emission inventory used (e.g. Shindell et al., 2006; Kopacz et al., 2010; Fortems-Cheiney et al., 2011), and 

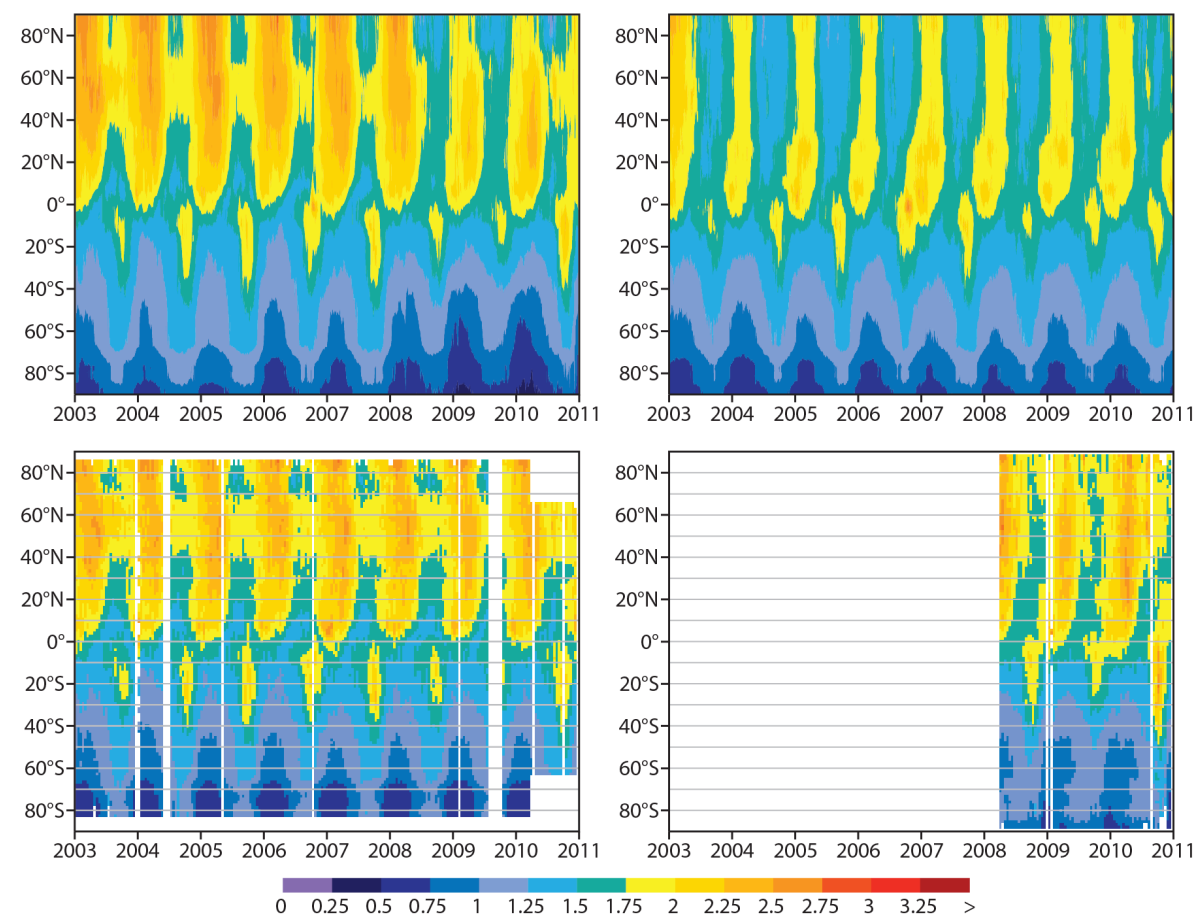

Fig. 2. Time series of zonal mean total column CO field in $10^{18}$ molecules $\mathrm{cm}^{-2}$ for the period 2003 to 2010 from the MACC reanalysis (top left), the control run (top right), MOPITT (bottom left) and IASI (bottom right). The MOPITT time series shows the change to NRT data in 2010 , for which no data are available polewards of $65^{\circ}$. Red indicates higher values of the field, blue lower values.

that the MACCity anthropogenic emissions are in the same range as the emissions provided by the few other emission inventories available for the post-2000 period (Granier et al., 2011a). MACCity CO emissions are much higher than the most recent inventory developed for 2005, i.e. EDGAR-v4. In the MACC project offline simulations with the MOZART3 CTM were conducted to test the model sensitivity to different emission inventories. It was found that the model results improved when increasing anthropogenic $\mathrm{CO}$ and VOC emissions or when changing the wet deposition in the CTM. Further studies are being carried out to establish exactly why the MACCity emissions and other emission inventories lead to low $\mathrm{CO}$ values in the coupled IFS-MOZART system.

\subsection{Control run}

It would have been computationally too expensive to produce a control analysis experiment that was identical to the MACC reanalysis, but did not actively assimilate observations of reactive gases. Instead, a MOZART-3 stand-alone run was carried out that applied the same settings (model code, resolution, emissions) as MOZART in the MACC reanalysis. The meteorological data for the stand-alone run were taken from the reanalysis, but the control run had free-running chemistry. The results from this control run can be used to detect the impact of the assimilation of GRG observations in the MACC reanalysis. Since the meteorological input data were derived from interpolation of archived 6-hourly output from the MACC reanalysis, and not through hourly exchange as in the reanalysis, the stand-alone run was not a completely clean control run. However, these differences would be small.

\section{Results}

This section presents fields from the MACC reanalysis and compares them with observations. It provides a basic first assessment of the quality of the reactive gas reanalysis fields, and it highlights problems in the reanalysis that users should be aware of. Shown are time series and seasonal climatologies of the MACC analysis fields, as well as comparisons with independent observations where possible. Also shown are some results from the control run to highlight the impact of assimilating atmospheric composition data on the reanalysis fields. First, $\mathrm{CO}, \mathrm{O}_{3}$ and $\mathrm{NO}_{\mathrm{x}}$ analysis fields are assessed for which observations were assimilated in the MACC reanalysis (see Table 1). Subsequently, results are presented for $\mathrm{HCHO}$ fields where no observations were assimilated in the MACC reanalysis.

\subsection{CO analysis}

MOPITT version $4 \mathrm{CO}$ retrievals were assimilated in the MACC reanalysis (see Table 1) from 2003 to 2010. IASI CO retrievals were assimilated from April 2008 onwards. Both 


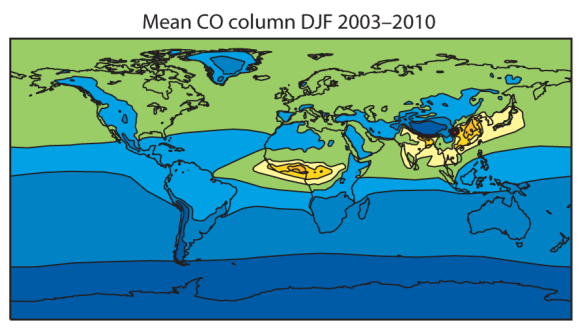

Mean CO column JJA 2003-2010

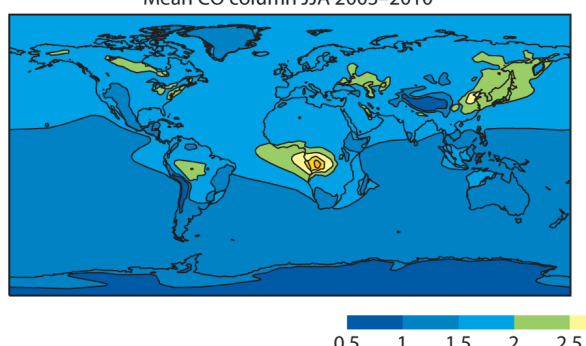

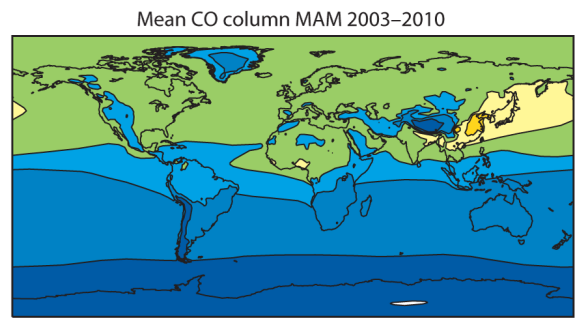

Mean CO column SON 2003-2010

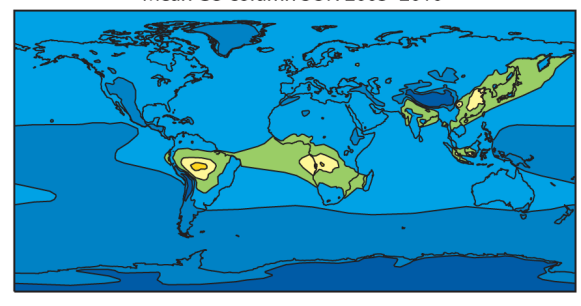

$3 \quad 3.5 \quad 4 \quad 4.5 \quad 5$

Fig. 3. Seasonal mean CO total columns from the MACC reanalysis in $10^{18}$ molecules $\mathrm{cm}^{-2}$ for DJF (top left), MAM (top right), JJA (bottom left) and SON (bottom right), averaged over the years 2003 to 2010. Red indicates higher values of the field, blue lower values.

instruments measure in the thermal infrared part of the spectrum and provide data during day and night. In the MACC reanalysis both day- and night-time data were assimilated. Because averaging kernels were used in the observation operators, differences in sensitivity to $\mathrm{CO}$ in the lower troposphere between day- and night-time observations (Deeter et al., 2003) were accounted for in the analysis.

Figure 2 shows time series of zonal mean total column $\mathrm{CO}$ data from the MACC reanalysis, the control run, MOPITT and IASI data for the period 2003-2010. The CO field shows a pronounced seasonal cycle in both hemispheres, as well as differences between the hemispheres. Larger anthropogenic emissions in the $\mathrm{NH}$ lead to larger $\mathrm{CO}$ values compared to the SH. The $\mathrm{NH}$ emissions peak in late winter/early spring because of increased fossil fuel burning for heating and increased power requirements (Edwards et al., 2004). This together with the seasonal cycle of $\mathrm{OH}$ which accounts for $90 \%$ of CO loss (Thompson, 1992) leads to maximum $\mathrm{CO}$ values in the $\mathrm{NH}$ in March and April. In the SH, the seasonal cycle is determined by a large contribution from biomass burning and some contribution from the oxidation of biogenic VOCs that lead to high CO values between the equator and $40^{\circ} \mathrm{S}$, with maximum values during September and October, the months of peak fire activity in the SH (Torres et al., 2010; Kaiser et al., 2012). The interannual variability is dominated by changing emissions from biomass burning in both hemispheres (Kaiser et al., 2012) which is largely related to precipitation rates (Torres et al., 2010). In the SH, CO maxima are lower in 2003, 2008 and 2009 compared to other years. In October 2006 a CO maximum is visible just south of the equator. This is a result of the 2006 wildfires in Indonesia, which led to the highest $\mathrm{CO}$ emissions over Indonesia in over a decade (Fortems-Cheiney et al., 2011;
Kaiser et al., 2012). The lower values seen in the reanalysis in the NH from 2008 onwards are the result of assimilating IASI data in addition to MOPITT data.

The reanalysis agrees well with the assimilated MOPITT and IASI data. However, the control run with the freerunning MOZART-3 CTM underestimates $\mathrm{CO}$ concentrations. It starts from realistic initial conditions, but drifts towards lower $\mathrm{CO}$ concentrations within the first 6 months, though the seasonal cycle is well represented. The low bias of the control points to either a problem with the MACCity emissions or a short coming in the MOZART CTM, and is being investigated in other studies.

Figure 3 shows the reanalysis seasonal mean CO columns for the years 2003-2010. The figure again highlights the interhemispheric differences, with $\mathrm{CO}$ values generally larger in the $\mathrm{NH}$ than in the $\mathrm{SH}$, except in the biomass burning regions in the tropics. This reflects the greater anthropogenic emissions in the NH (e.g. Fortems-Cheiney, 2011). The largest values are found over south east Asia in December, January and February (DJF) and March, April and May (MAM), and there is transport of $\mathrm{CO}$ rich air from south east Asia out into the Pacific. Values in the NH have a minimum in June, July and August (JJA) and are still low in September, October and November (SON).

$\mathrm{CO}$ from biomass burning in the tropics shows a different seasonality. In Africa, maximum CO columns are seen north of the equator in DJF, when biomass burning takes place in the Sahel region and equatorial West Africa during the local dry season. In MAM the fire signal over Africa is much weaker, and by JJA the affected area moves south of the equator. In SON the signal is weaker than in JJA but extends further to the south and east. This agrees well with studies by Torres et al. (2010), who found that biomass burning 

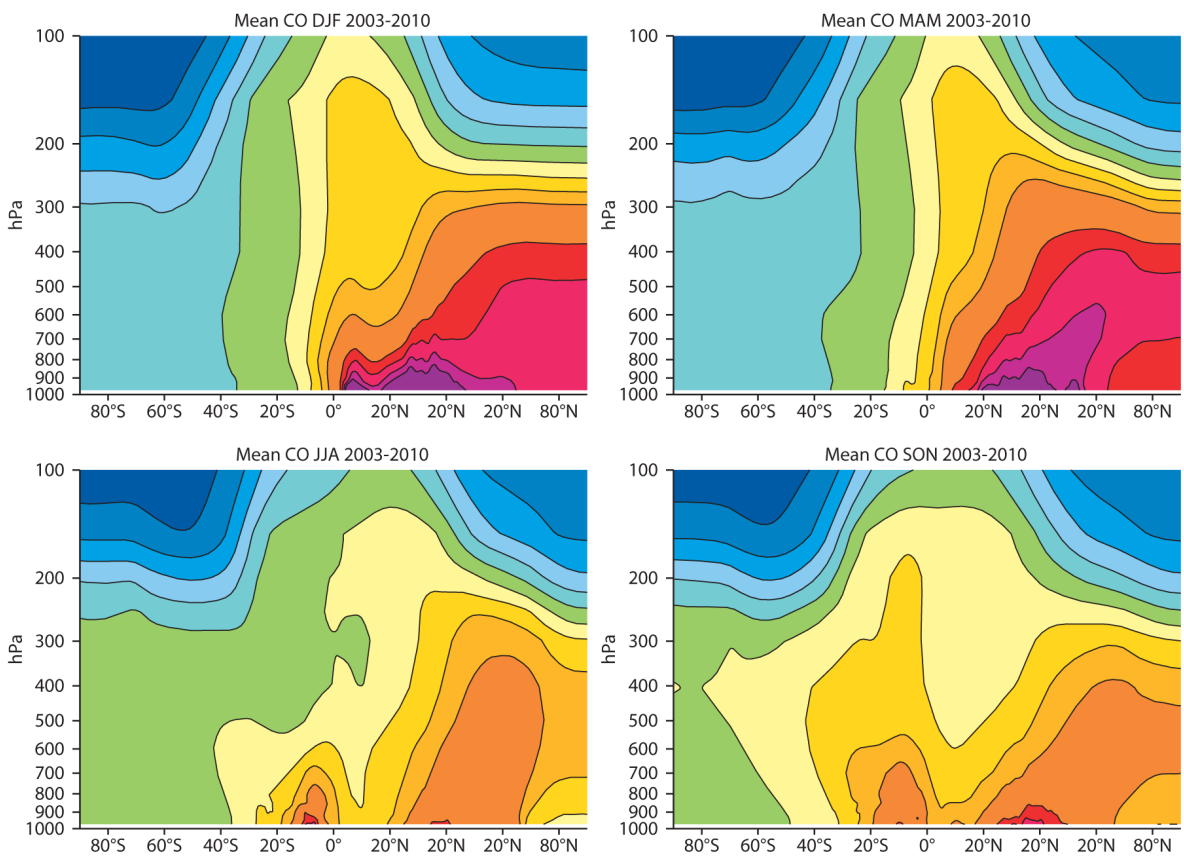

$0 \quad 10 \quad 203040 \quad 5060 \quad 70 \quad 8090100120130140150$

Fig. 4. Seasonal mean zonal average CO altitude cross sections from the MACC reanalysis in ppbv for DJF (top left), MAM (top right), JJA (bottom left) and SON (bottom right), averaged over the years 2003 to 2010. Red indicates higher values of the field, blue lower values.

in Central Africa normally starts in June at about $10^{\circ} \mathrm{S}$ and then moves southwards. It generally peaks in August, but the season extends to November. In all seasons, there is indication of $\mathrm{CO}$ rich air being transported from Africa downwind into the Atlantic. Convective activity over Africa (and also over South America) transports the smoke into the free troposphere from where it is then transported by the prevailing winds (e.g. Jonquières et al., 1998; Mari et al., 2008; Real et al., 2010).

In South America the strongest biomass burning signal is seen in SON. Deforestation fires and agricultural fires occur south of $10^{\circ} \mathrm{S}$ during August-October with a peak in September. In Indonesia and north-west Australia, the strongest biomass burning signal is also seen in SON, but the climatological biomass burning signal here is weaker than over Africa and South America. The large values over Indonesia in SON come from the strong fires in 2006 (see also Fig. 2).

The vertical structure of the MACC CO field in the troposphere can be seen in the seasonal mean cross sections in Fig. 4. In the NH the highest values are found in DJF and MAM when anthropogenic emissions are largest and the photochemical lifetime of $\mathrm{CO}$ is longest. There is some indication of large-scale convective transport lifting $\mathrm{CO}$ into the upper troposphere in the tropics. Deep convection is known to carry biomass burning products into the upper troposphere (Pickering et al., 1996; Thompson et al., 1996; Kar et al., 2004). In the SH, high CO from biomass burning can be seen between $0-20^{\circ}$ in $\mathrm{JJA}$ and $\mathrm{SON}$, and again there is evidence of large-scale transport lifting $\mathrm{CO}$ into the free troposphere.

To validate $\mathrm{CO}$ from the reanalysis, fields are compared with independent observations, i.e. data that were not used in the assimilation. Figure 5 shows a comparison of $\mathrm{CO}$ concentrations from the reanalysis with NOAA Global Monitoring Division (NOAA/GMD) ground-based measurements (Novelli and Masarie, 2010) over Mace-Head, Tenerife, Key Biscayne and South Pole stations. The uncertainty of the NOAA/GMD CO observations is around 1-3 ppmv (Novelli et al., 2003). The results show that the magnitude and seasonal variability of surface $\mathrm{CO}$ is generally well captured by the reanalysis over most stations and improved compared to the control run, apart from at the South Pole from 20032007. This indicates that, despite low sensitivity of satellite measurements near the surface, assimilation of $\mathrm{CO}$ data from such products can lead to a good representation of surface $\mathrm{CO}$ concentrations. Assimilation of satellite measurements can therefore overcome to some extent the underestimation of surface $\mathrm{CO}$ concentrations in the Northern Hemisphere seen in most global models (Holloway et al., 2000; Shindell et al., 2006; Isaksen et al., 2009), which could be related to uncertainties in surface emissions as mentioned in Sect. 2.4. The reanalysis agrees better with the observations over the South Pole station after April 2008, i.e. after the assimilation of IASI CO data was introduced. On the other hand, over some stations at high northern latitudes (at the stations Alert and Barrow, not shown), the reanalysis tends 

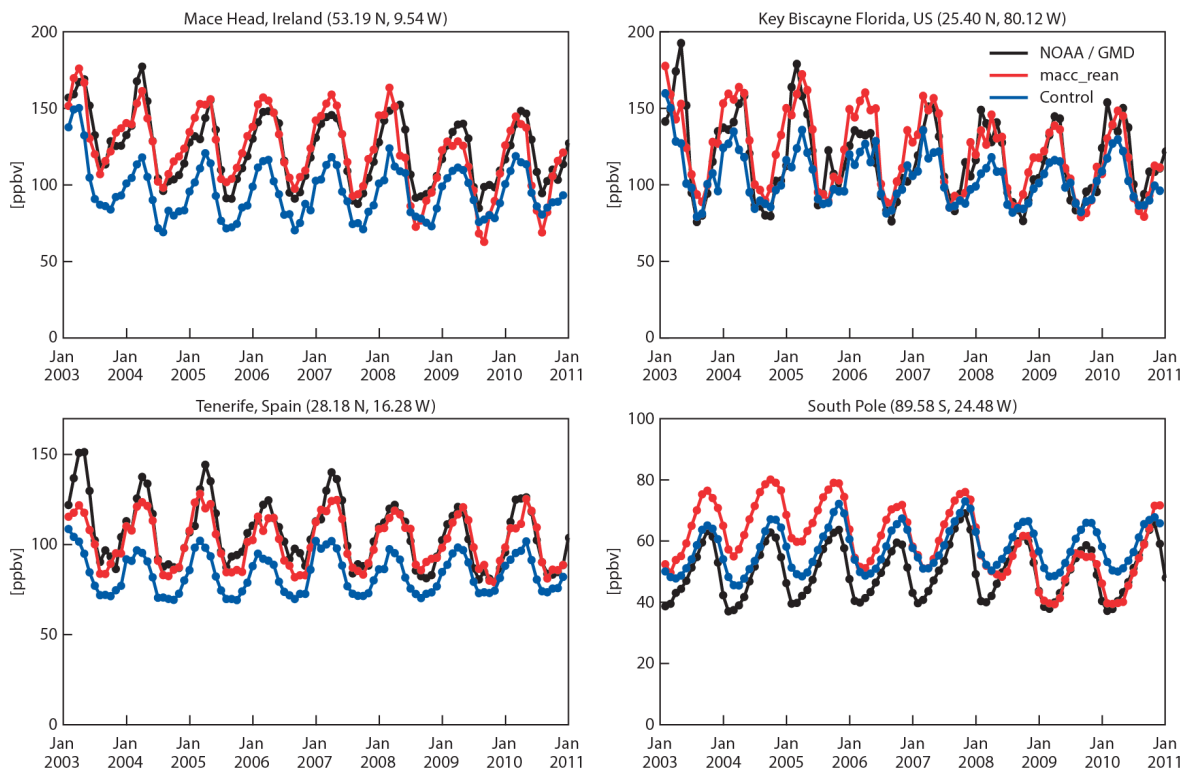

Fig. 5. Time series (2003-2010) of monthly mean CO concentrations (ppbv) from the MACC reanalysis (red), the control run (blue), and from NOAA/GMD ground-based measurements (black) over Mace-Head (top left), Key Biscayne (top right), Tenerife (bottom left), and South Pole (bottom right) stations.

to underestimate $\mathrm{CO}$ during the same period. These lower values after April 2008 can also be seen in Fig. 2.

Next, CO from the reanalysis is compared with data from the MOZAIC (Measurement of Ozone, Water Vapour, Carbon Monoxide and Nitrogen Oxides by Airbus In-service Aircraft) programme (Marenco et al., 1998; Nedelec et al., 2003). This programme provides profiles of various parameters, including $\mathrm{CO}$ and $\mathrm{O}_{3}$ taken during aircraft ascents and descents at various airports. MOZAIC data were available from January 2003 until December 2010, with limited data availability in 2010. MOZAIC CO data have an accuracy of \pm 5 parts per billion volume (ppbv), a precision of $\pm 5 \%$, and a detection limit of 10 ppbv (Nedelec et al., 2003).

Figure 6 shows the time mean vertically averaged relative $\mathrm{CO}$ bias between 300 and $1000 \mathrm{hPa}$ from the MACC reanalysis. The reanalysis has a negative bias in the troposphere with the exception of a few airports. The averaged biases are usually less than $15 \%$, but larger at some tropical airports. The control run has a bias that is more than twice as large (not shown).

Figure 7 shows time mean profiles from the reanalysis (red) and the MOZAIC data (black) averaged over NH extratropical airports (solid lines) and tropical airports (dashed lines). Also shown are the mean differences between the reanalysis and MOZAIC data for both hemispheres. The highest $\mathrm{CO}$ concentrations are found near the surface and values get smaller in the free troposphere. The biases between 700 $300 \mathrm{hPa}$ are less than $-5 \%$ in the $\mathrm{NH}$ and around $-10 \%$ in the tropics, but larger in the lower troposphere. By assimilating $\mathrm{CO}$ satellite data, the biases are greatly reduced in

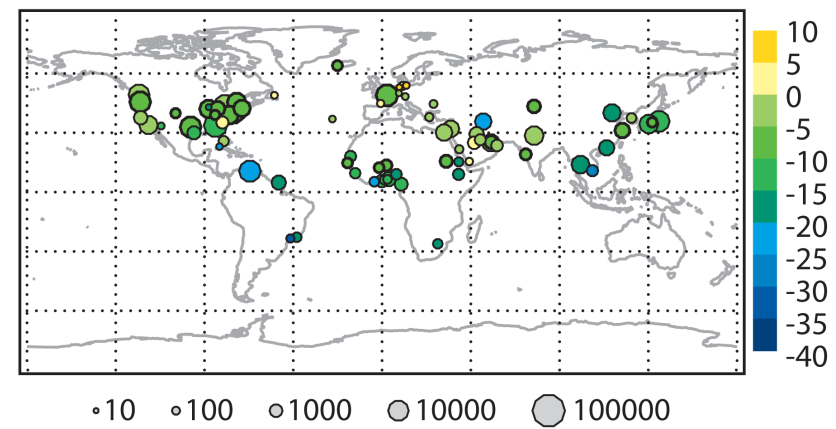

Fig. 6. Vertically (300-1000 $\mathrm{hPa}$ ) averaged $\mathrm{CO}$ bias in \% of MACC reanalysis minus MOZAIC ascent/descent data averaged over the period January 2003 to December 2010. The diameter of the circles indicates the number of profiles over the respective airports. Red indicates higher values of the field, blue lower values.

the reanalysis compared to the control run without data assimilation. This was also seen by Elguindi et al. (2010). The assimilated satellite data have only limited sensitivity to $\mathrm{CO}$ in the lower troposphere (see Fig. 1). Here the influence of the emissions is important and accurate emissions are crucial to reproducing the high $\mathrm{CO}$ values seen in the MOZAIC data. The low bias of the MACC reanalysis suggests an underestimation of $\mathrm{CO}$ or precursor emissions (Elguindi et al., 2010) or a missing process in the CTM. The importance of the emissions for correct $\mathrm{CO}$ values in the lower troposphere in the MACC system was also found in a study of the 2010 Russian wildfires (Huijnen et al., 2012). Furthermore, some of the bias in the lower troposphere is likely to be a 

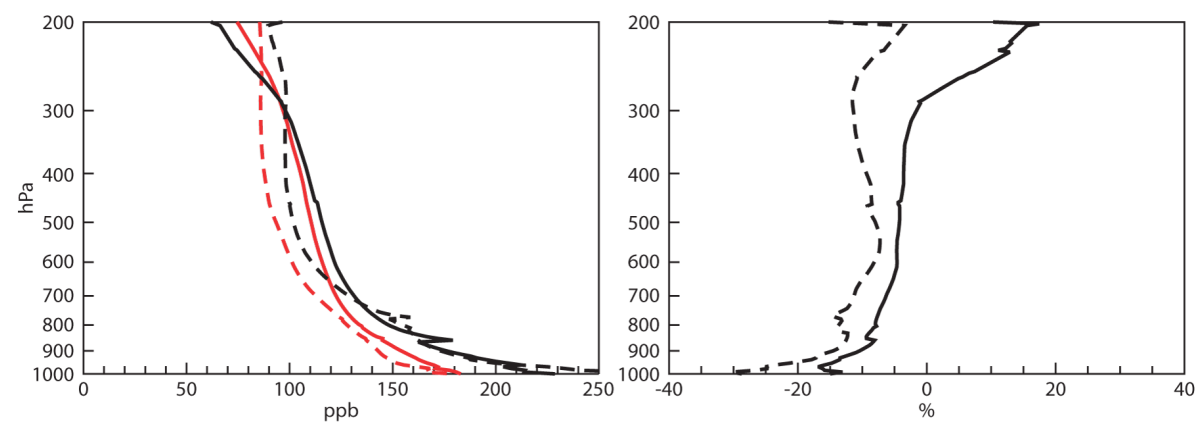

Fig. 7. Left panel: mean CO profiles in ppbv from the MACC reanalysis (red) and MOZAIC data (black). The solid lines show the means for $\mathrm{NH}$ airports (north of $30^{\circ} \mathrm{N}$ ), the dashed lines the means for tropical airports $\left(30^{\circ} \mathrm{S}-30^{\circ} \mathrm{N}\right)$. Right panel: CO bias in $\%$ of MACC reanalysis minus MOZAIC for NH airports (solid) and tropical airports (dashed). Data are averaged over the period January 2003 to December 2010.

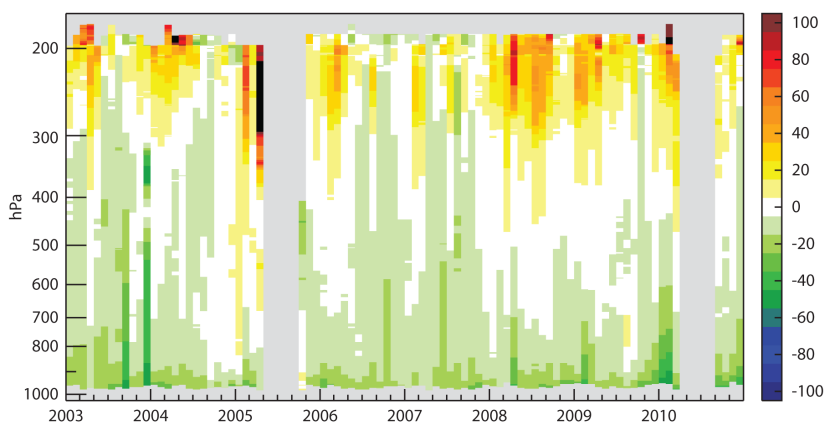

Fig. 8. Time series of monthly mean CO biases (MACC reanalysis minus MOZAIC) in \% at Frankfurt Airport $\left(50.0^{\circ} \mathrm{N}, 8.6^{\circ} \mathrm{E}\right)$ for the period January 2003 to December 2010. Red indicates higher values of the field, blue lower values.

representativeness error, because the model with a horizontal resolution of T255 (corresponding to a reduced Gaussian grid of about $80 \mathrm{~km} \times 80 \mathrm{~km}$ ) is not able to reproduce the high values observed by MOZAIC over polluted airports. Larger positive biases are seen in the $\mathrm{NH}$ above $300 \mathrm{hPa}$.

Figure 8 shows a time series of monthly mean $\mathrm{CO}$ bias profiles at Frankfurt Airport. Frankfurt is the most frequented airport in the MOZAIC database and the most reliable in terms of data availability. A total of 7182 MOZAIC profiles were available over Frankfurt between January 2003 and December 2010. Concentrations are larger during the winter months and larger concentrations extend higher up in the troposphere. The plot confirms that $\mathrm{CO}$ is underestimated in the surface layer as seen in Fig. 7. This was also found for other MOZAIC urban sites affected by air pollution such as Beijing, Tokyo and Cairo (not shown). Whilst the bias is generally less than $10 \%$ in the free troposphere $(850 \mathrm{hPa}$ to the upper troposphere), large positive biases are found in the upper troposphere and lower stratosphere, with the largest values during winter and spring, possibly due to too much upward transport of CO.

\section{2 $\mathrm{O}_{3}$ analysis}

The ozone retrievals assimilated in the MACC reanalysis are listed in Table 1. MIPAS and MLS measure in the midinfrared and microwave part of the spectrum, respectively, and are the only ozone data used in the MACC reanalysis that are available independent of illumination condition, including during the polar night. Together with the GOME $\mathrm{O}_{3}$ profile retrievals, they are also the only assimilated ozone profile data with higher vertical resolution, which had been shown in the past to be crucial for obtaining a realistic vertical ozone distribution in MACC and ECMWF analyses (Dethof, 2003; Flemming et al., 2011b). By assimilating GOME, MIPAS or MLS data with their vertically resolved information in the stratosphere together with total column ozone data of OMI and SCIAMACHY, tropospheric ozone can also be constrained.

\subsubsection{Total column and stratospheric ozone}

Figure 9 shows time series of zonal mean total column ozone from the MACC reanalysis, the control run, SCIAMACHY and OMI data. The reanalysis shows a realistic seasonal cycle in both hemispheres. In the NH extratropics, ozone values are highest during Boreal winter and spring. This is a result of poleward and downward transport of ozone by the large-scale Brewer-Dobson circulation (Brewer, 1949; Dobson, 1956; Weber et al., 2011). In the tropics, where there is slow large-scale ascent and higher insolation, the ozone columns are lower. In the $\mathrm{SH}$, the reanalysis shows the very low values of the Antarctic ozone hole, and also the higher values seen in a belt around the Antarctic. The assimilation of MIPAS and MLS data gives information during the polar night when the UV instruments GOME, SBUV/2, SCIAMACHY and OMI can not observe the ozone field because there is no backscattered solar radiation.

The time series of total column ozone from the control run illustrates that the free-running model generally overestimates the ozone column. The control run has a positive total column bias compared to SCIAMACHY and OMI data 

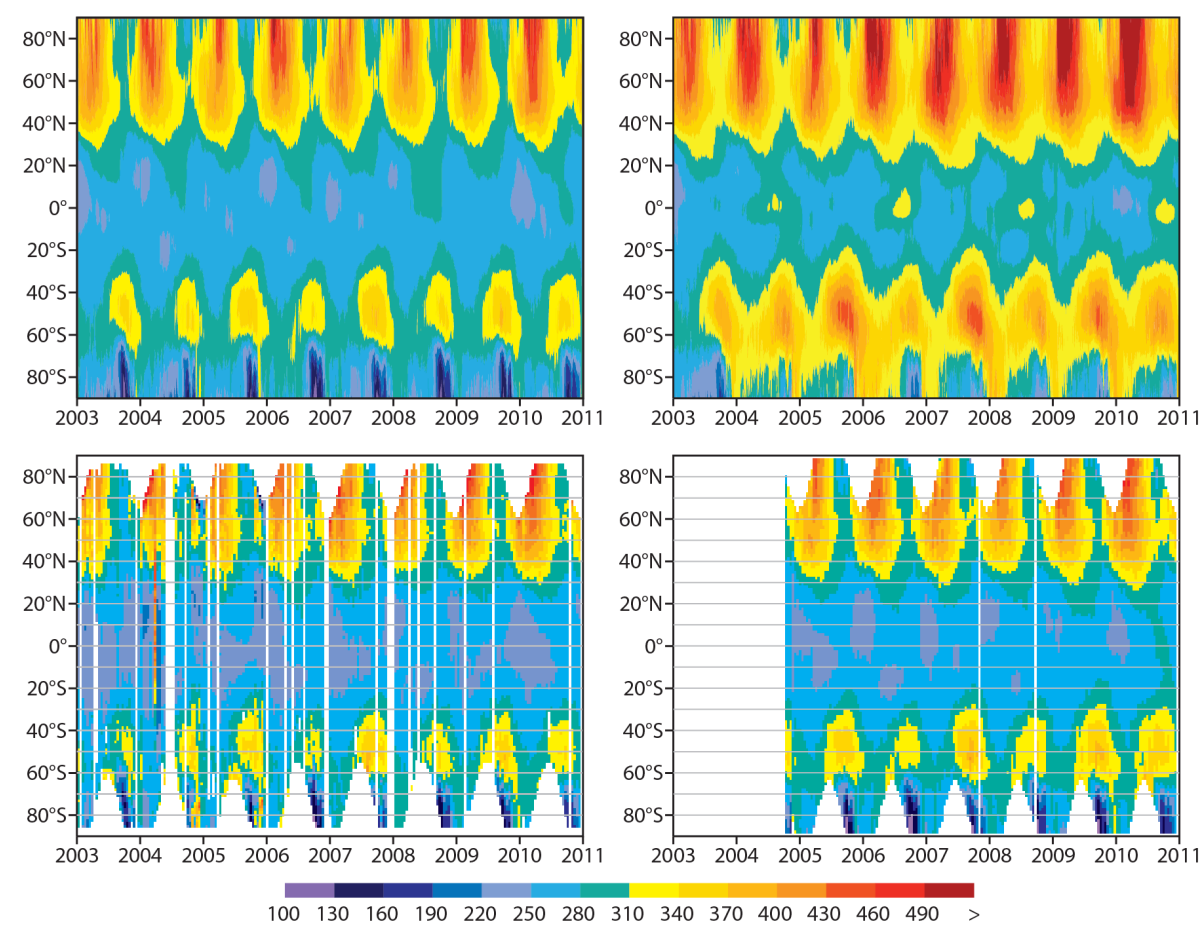

Fig. 9. Time series of zonal mean total column $\mathrm{O}_{3}$ field in Dobson units (DU) for the period 2003 to 2010 from the MACC reanalysis (top left), the control run (top right), SCIAMACHY (bottom left) and OMI (bottom right). Red indicates higher values of the field, blue lower values.

everywhere. This bias points to problems with the stratospheric ozone distribution in the MOZART-3 CTM, which dominates the ozone column. Similar results were found by Kinnison et al. (2007) when they used ECMWF meteorological fields to drive the MOZART-3 model. Also, the Antarctic ozone hole is not deep enough in the control run, a known problem of MOZART-3 in the MACC configuration (Flemming et al., 2011b).

Figure 10 shows the mean relative bias between the MACC reanalysis and KNMI's multi-sensor reanalysis (MSR, van der A et al., 2010) for the years 2003-2008, which is based on SBUV/2, GOME, TOMS, SCIAMACHY and OMI observations, and the SCIAMACHY data (Eskes et al., 2003) for the years 2003-2010, in order to evaluate the data after 2008. Bias correction of satellite retrievals in the MSR was done using Brewer and Dobson Spectrophotometers. There is good agreement between the data sets at various latitude bands, showing a clear improvement in total columns compared to the control run. Biases of the MACC reanalysis with respect to the MSR and the SCIAMACHY assimilation system are generally of similar magnitude, which constrains the evaluation for 2009-2010, for which no MSR data is available. Zonal-average, monthly mean biases of the reanalysis compared to the MSR over the extratropical Northern Hemisphere are less than $3 \%$. The reanalysis shows a general positive bias except for the $\mathrm{NH}$ winter season. During this season observed average $\mathrm{O}_{3}$ total columns increase. The negative biases suggest a slightly too slow response of the reanalysis to this increase, compared to the MSR. Biases in the tropics are very small $(<2 \%)$. Only during a period of $\sim 1.5 \mathrm{yr}$, mainly covering 2008 , was a slightly larger bias of $\sim 3 \%$ found. Over the extratropical Southern Hemisphere, the biases are less than 5\% during 2003-2004, and below $3 \%$ during later years when MLS and OMI data were assimilated. The seasonal oscillations seen in the $\mathrm{NH}$ and $\mathrm{SH}$ are the result of a seasonally varying model bias in the MOZART-3 CTM and the fact that MLS and MIPAS data are assimilated in the reanalysis and give information about ozone in the polar night that is not included in the MSR.

Seasonal mean climatologies of total column ozone from the reanalysis for the years 2003-2010 are shown in Fig. 11. The figure shows the largest ozone columns over the NH extratropics in DJF and MAM, and the lowest values in SON, as already seen in Fig. 9. In the tropics the lowest values are seen in DJF, when the Brewer-Dobson circulation is strongest. In the $\mathrm{SH}$, the Antarctic ozone hole is visible in SON, with seasonal mean total column values lower than 200 DU. Ozone columns in the circum-Antarctic belt are at their highest in SON, when large-scale descent brings down ozone rich air.

The vertical structure of the MACC ozone field can be seen in the seasonal mean cross sections in Fig. 12. Ozone concentrations in the stratosphere are the result of the balance of ozone production, ozone loss and transport. The figure 

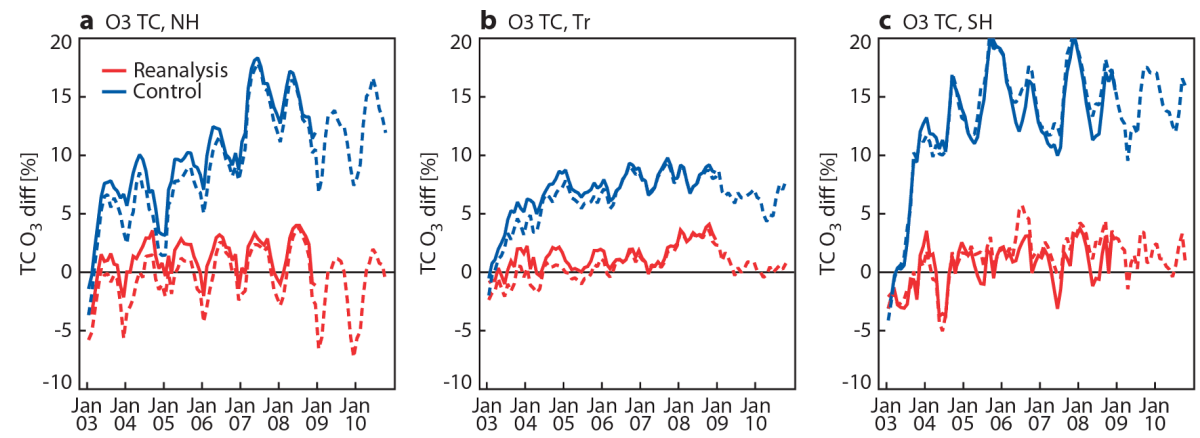

Fig. 10. Time series of the mean difference of the MACC reanalysis minus total $\mathrm{O}_{3}$ columns from the multi-sensor reanalysis (solid) and SCIAMACHY fields (dashed) in $\%$ averaged over (a) the $\mathrm{NH}$ extratropics $\left(30^{\circ} \mathrm{N}-90^{\circ} \mathrm{N}\right)$, (b) the tropics $\left(30^{\circ} \mathrm{S}-30^{\circ} \mathrm{N}\right)$, and $(\mathbf{c})$ the $\mathrm{SH}$ extratropics $\left(90^{\circ} \mathrm{S}-30^{\circ} \mathrm{S}\right)$ for the years 2003 to 2010 . Red lines show the MACC reanalysis and blue lines the control run.

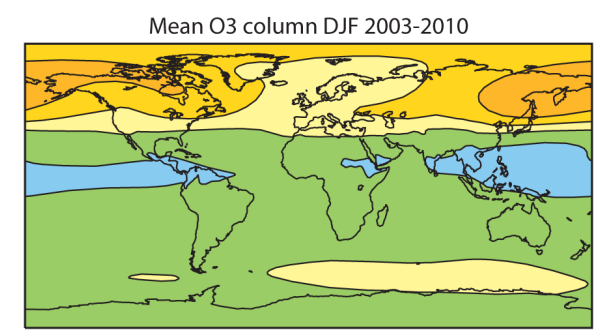

Mean O3 column JJA 2003-2010

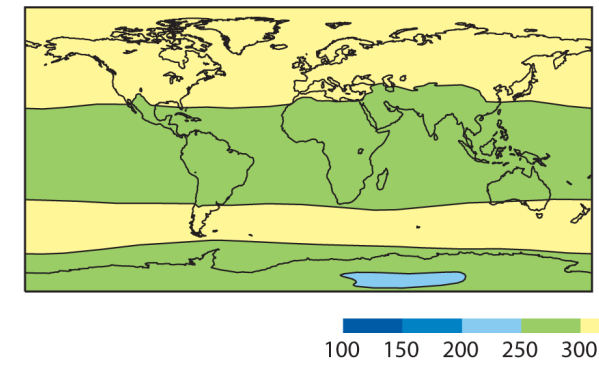

Mean O3 column MAM 2003-2010

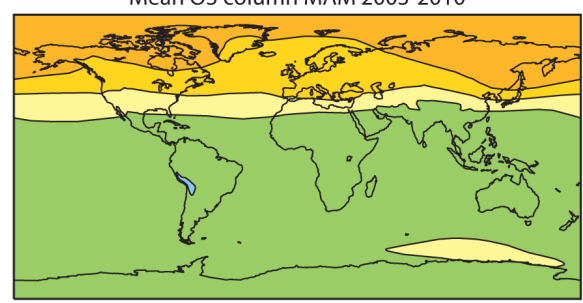

Mean O3 column SON 2003-2010

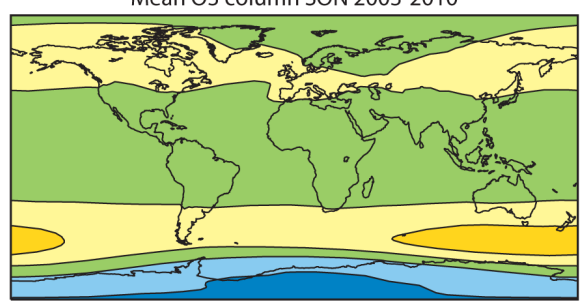

Fig. 11. Seasonal mean total column ozone field from the MACC reanalysis in DU for DJF (top left), MAM (top right), JJA (bottom left) and SON (bottom right), averaged over the years 2003 to 2010. Red indicates higher values of the field, blue lower values.

clearly depicts the ozone layer which is at higher altitude in the tropics than in the extratropics. The concentrations in the tropics are lowest in DJF when the upwelling branch of the Brewer-Dobson circulation is strongest. At the same time, the ozone layer in the $\mathrm{NH}$ extratropics is strongest because descent brings ozone rich air down. In SON, the impact of the chemical ozone destruction over Antarctica is clearly visible. Here the ozone layer is very thin and partial pressure values around the ozone maximum are less than $9 \mathrm{mPa}$ in the seasonal mean.

Next, MACC ozone is validated against independent data that were not assimilated in the reanalysis. First, stratospheric ozone fields from the reanalysis are compared with data from the Atmospheric Chemistry Experiment Fourier Transform Spectrometer (ACE-FTS, Dupuy et al., 2009). ACE-FTS data show good agreement with correlative measurements, with a small positive bias with mean relative differences of about $+5 \%$ between $15-45 \mathrm{~km}$, and a larger positive bias above $42-45 \mathrm{~km}$ (Dupuy et al., 2009). ACE-FTS data were available from January 2004 to September 2010, with a gap from December 2009 to May 2010. Figure 13 shows time series of monthly mean relative biases between the reanalysis and ACE-FTS data at 10, 46 and $100 \mathrm{hPa}$ for extra-polar and polar regions. The reanalysis generally has a small positive bias. At $100 \mathrm{hPa}$ the biases are less than $10 \%$ in most regions. Noticeable are larger biases between April and August 2004 and after March 2009, a result of changes in the assimilated data. Between April and August 2004, no ozone profile data were assimilated in the reanalysis because MIPAS data were not available anymore and MLS data were not available yet. The larger biases after March 2009 are the result of assimilating NRT MLS data (see Table 1). For the NRT MLS data, the data producers recommend not to use the ozone values below $64 \mathrm{hPa}$ (bottom three levels) because those values are largely 

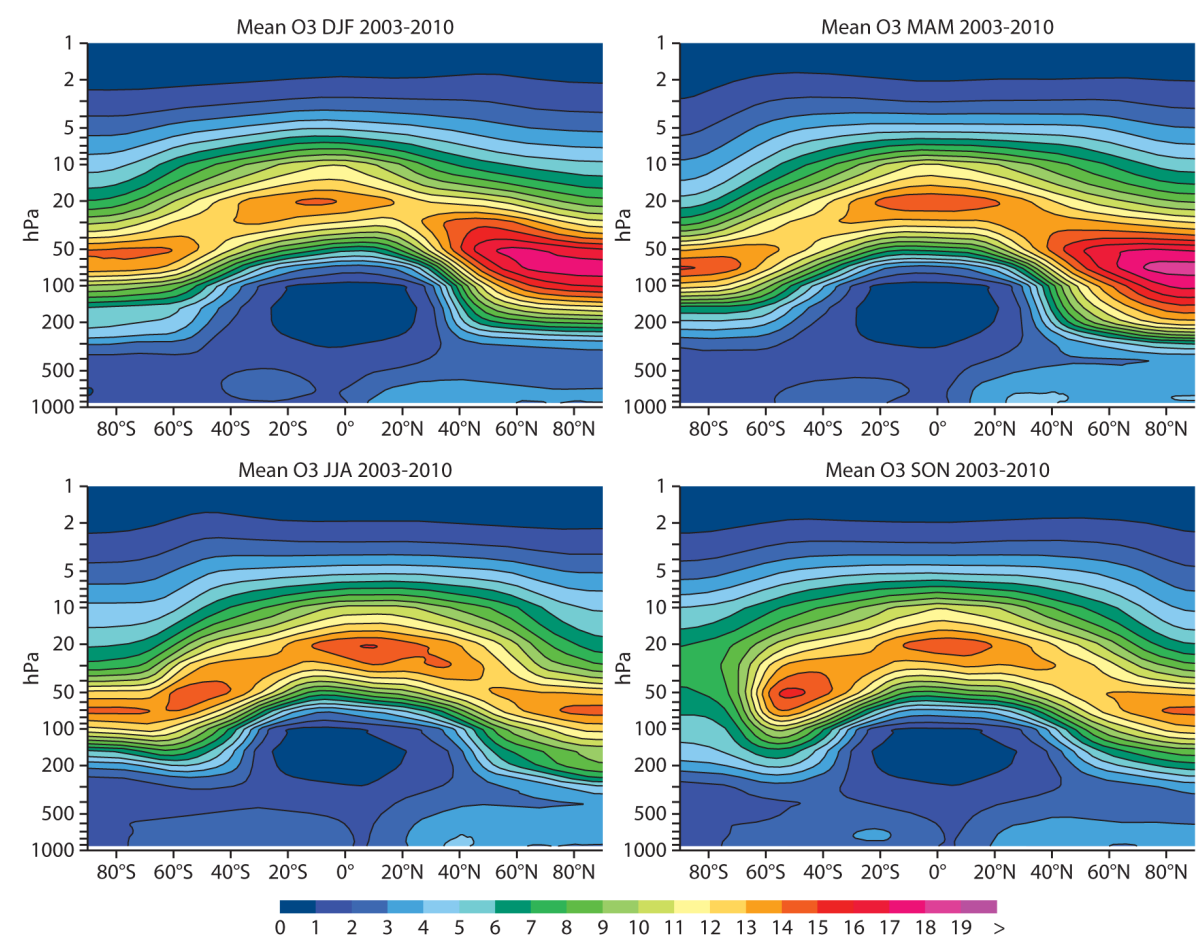

Fig. 12. Seasonal mean zonal average ozone cross sections from the MACC reanalysis in mPa for DJF (top left), MAM (top right), JJA (bottom left) and SON (bottom right), averaged over the years 2003 to 2010. Red indicates higher values of the field, blue lower values.

influenced by the a priori of the retrieval. Therefore, the NRT MLS data can not constrain ozone in the lower stratosphere and upper troposphere. The largest negative biases at $100 \mathrm{hPa}$ are seen over the South Pole in September and November.

The change to NRT MLS data does not have a noticeable impact at higher levels ( 46 and $10 \mathrm{hPa}$ ). At $46 \mathrm{hPa}$, the biases are less than $10 \%$ in the extra-polar regions and less than $5 \%$ in the polar regions. At $10 \mathrm{hPa}$ we see an impact of the changed bias correction in January 2008 (Sect. 2.3.2), particularly in the polar regions, and biases are reduced after January 2008. At 46 and $100 \mathrm{hPa}$ the change to the variational bias correction does not have a noticeable impact. In this altitude range, where the bulk of the ozone column is located, the ozone bias correction is successfully anchored by SBUV/2 data alone. The monthly mean standard deviations of the differences between ACE-FTS data and the reanalysis are usually around $10 \%$ at 10 and $46 \mathrm{hPa}$, but up to $20 \%$ at $100 \mathrm{hPa}$, and even larger over the South Pole during the ozone hole season (not shown).

Figure 14 shows profiles of seasonal mean relative biases of MACC ozone with respect to ACE-FTS data for extratropical and tropical areas. The biases are negative above $3 \mathrm{hPa}$ and below $100 \mathrm{hPa}$ (where ACE-FTS errors are large) and mainly positive between 3 and $100 \mathrm{hPa}$. In the stratosphere, they are smallest between 20 and $50 \mathrm{hPa}$ where they are less than $5 \%$ for most areas. The largest positive bias of up to $15 \%$ is found around $10 \mathrm{hPa}$, i.e. at the level of maxi- mum ozone mixing ratio. Below $100 \mathrm{hPa}$ the ACE-FTS data have large uncertainties.

Next, MACC ozone is compared with ozonesonde data. The ozonesondes are available for the whole $8 \mathrm{yr}$ of the reanalysis and come from a variety of data sources: World Ozone and Ultraviolet Radiation Data Centre (WOUDC), Southern Hemisphere ADditional OZonesondes (SHADOZ), Network for the Detection of Atmospheric Composition Change (NDACC), and campaigns for the Determination of Stratospheric Polar Ozone Losses (MATCH), and from the ECMWF Meteorological Archive and Retrieval System (MARS). The precision of electrochemical concentration cell ozonesondes is on the order of $\pm 5 \%$ in the range between 200 and $10 \mathrm{hPa}$, between $-14 \%$ and $+6 \%$ above $10 \mathrm{hPa}$, and between $-7 \%$ and $+17 \%$ below $200 \mathrm{hPa}$ (Komhyr et al., 1995). Larger errors are found in the presence of steep gradients and where the ozone amount is low. The same order of precision was found by Steinbrecht et al. (1998) for BrewerMast sondes. We did not include carbon-iodine sondes in the validation because they have larger biases.

Figure 15 shows the time mean vertically averaged relative biases between 5 and $100 \mathrm{hPa}$ from the MACC reanalysis minus ozonesondes. The mean stratospheric biases are less than $\pm 10 \%$ for most stations and in many cases even less than $\pm 5 \%$. Larger biases are found over south east Asia. The control run has considerably larger positive biases in the stratosphere than the reanalysis. Biases of up to $40 \%$ can be 


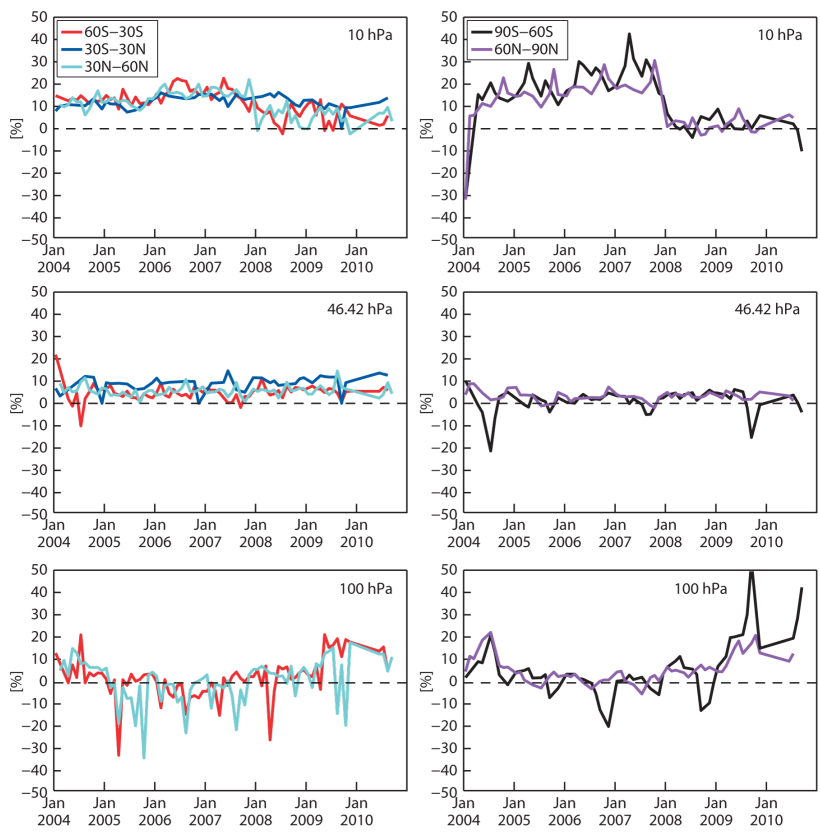

Fig. 13. Time series of monthly mean relative ozone biases between the MACC reanalysis and ACE-FTS data (MACC minus ACE-FTS) in \% for the period January 2004 to September 2009 at $10 \mathrm{hPa}$ (top), $46 \mathrm{hPa}$ (middle), and $100 \mathrm{hPa}$ (bottom). The left panels show time series for extra-polar regions, the right panels time series for polar regions. There are not enough good quality ACE-FTS data at $100 \mathrm{hPa}$ between $30^{\circ} \mathrm{S}$ and $30^{\circ} \mathrm{N}$ for a meaningful validation; hence this curve is omitted from the bottom left panel. Red lines show averages for the area $60^{\circ} \mathrm{S}-30^{\circ} \mathrm{S}$, dark blue for $30^{\circ} \mathrm{S}-30^{\circ} \mathrm{N}$, light blue for $30^{\circ} \mathrm{N}-60^{\circ} \mathrm{N}$, black for $90^{\circ} \mathrm{S}-60^{\circ} \mathrm{S}$ and purple for $60^{\circ} \mathrm{N}-90^{\circ} \mathrm{N}$.

seen over Antarctica, which is in agreement with the large total column biases seen in Fig. 9.

To assess the vertical structure of these biases in more detail, Fig. 16 shows time averaged ozone profiles and bias profiles from the reanalysis and ozonesondes for the $\mathrm{NH}$ extratropics, the tropics, and the SH extratropics. The figure demonstrates that the reanalysis agrees to within $\pm 5 \%$ in the $\mathrm{NH}$ and to within $-5 \%$ to $+10 \%$ in the $\mathrm{SH}$, where the largest biases are seen near the surface. In the tropics the reanalysis and sondes agree to within $\pm 10 \%$ above $70 \mathrm{hPa}$, but have larger negative relative differences below $100 \mathrm{hPa}$. The tropospheric bias is discussed further in the next subsection.

\subsubsection{Tropospheric ozone}

Figure 16 shows larger tropospheric than stratospheric relative biases between MACC ozone and ozonesondes, particularly in the tropics. To investigate this bias in more detail, the reanalysis ozone is compared with ozonesondes and MOZAIC data in the altitude range between 200 and $1000 \mathrm{hPa}$. The MOZAIC ozone data have a detection limit of
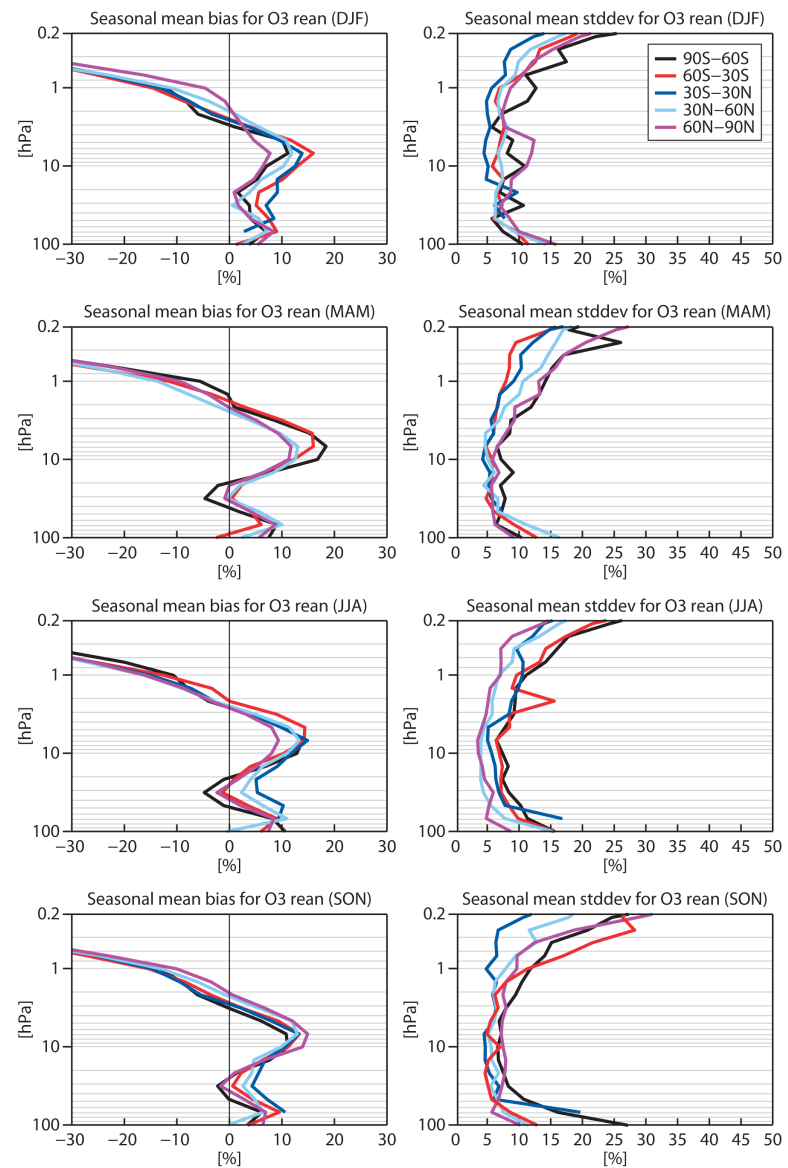

Fig. 14. Seasonally averaged relative ozone bias profiles (left) of MACC reanalysis minus ACE-FTS data, and seasonally averaged standard deviation profiles of the differences (right) in \% for polar and extra-polar areas (as defined in the figures). Red lines show averages for the area $60^{\circ} \mathrm{S}-30^{\circ} \mathrm{S}$, dark blue for $30^{\circ} \mathrm{S}-30^{\circ} \mathrm{N}$, light blue for $30^{\circ} \mathrm{N}-60^{\circ} \mathrm{N}$, black for $90^{\circ} \mathrm{S}-60^{\circ} \mathrm{S}$ and purple for $60^{\circ} \mathrm{N}-$ $90^{\circ} \mathrm{N}$.

$2 \mathrm{ppbv}$ and a precision of $\pm(2 \mathrm{ppbv}+2 \%)$ (Marenco et al., 1998).

Figure 17 shows the mean relative ozone bias of MACC ozone with respect to ozonesondes and MOZAIC data averaged between 200 and $1000 \mathrm{hPa}$ averaged over the period from January 2003 to December 2010. With respect to ozonesondes, the reanalysis biases are within $\pm(5-10) \%$ in the $\mathrm{NH}$ and over the Antarctic, but larger negative biases are found in the tropics. With respect to MOZAIC data, the reanalysis has mainly positive biases of less than $10 \%$ over Europe and North and South America, and negative biases of up to $-10 \%$ over Africa. Larger positive biases with respect to MOZAIC are found over east Asia. Larger biases over east Asia were also seen for CO data (Fig. 6), suggesting that either the horizontal resolution is not high enough to reproduce the high values seen over polluted airports, that there could be problems with the vertical transport, or that the 


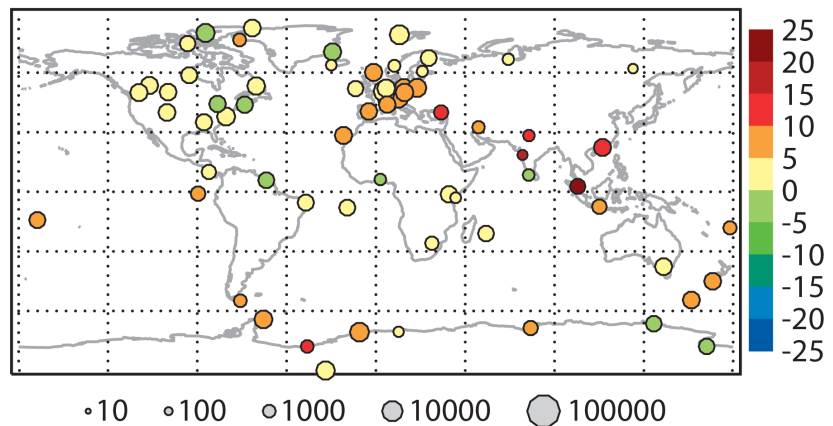

Fig. 15. Mean stratospheric $\mathrm{O}_{3}$ bias in $\%$ of MACC reanalysis minus ozonesonde data averaged between $5-100 \mathrm{hPa}$ for the period January 2003 to December 2010. The diameter of the circles indicates the number of profiles over the respective stations. Red indicates higher values of the field, blue lower values.

differences are due to the chemical coupling of $\mathrm{O}_{3}$ and other fields. At the very high $\mathrm{NO}_{\mathrm{x}}$ concentrations over Asia, especially in polluted regions near cities (where the airports are), $\mathrm{O}_{3}$ will be destroyed. The model has too little $\mathrm{NO}_{\mathrm{x}}$ here (see Sect. 3.3 below), so it might not destroy enough $\mathrm{O}_{3}$, which could explain the positive bias seen in these regions.

The differences seen in the biases with respect to ozonesondes and MOZAIC data are consistent with findings by Tilmes et al. (2012), who showed that ozonesondes measure higher concentrations than MOZAIC data in the free troposphere over western Europe and North and South America, but agree to within the given error bars. Saunois et al. (2012) investigated uncertainties as a result of different sampling frequencies and found these to be of the order $7-14 \%$ in the free troposphere and larger above and below. These sampling frequency uncertainties have to be considered when comparing ozonesonde and MOZAIC data, which have very different measurement frequencies, and they are large enough to explain the differences between the ozonesonde and MOZAIC biases seen in Fig. 17.

Figure 18 shows the time mean relative tropospheric bias profiles of the analysis minus ozonesondes and minus MOZAIC data. In the tropical troposphere, the reanalysis shows a large negative bias with respect to sondes above $650 \mathrm{hPa}$, and the opposite below. Elsewhere the biases are small which is in agreement with Fig. 17. Compared to MOZAIC data, the reanalysis shows the largest positive bias below $800 \mathrm{hPa}$. The bias of the reanalysis is around $5 \%$ in the free troposphere in the $\mathrm{NH}$ extratropics, and small and negative $(-10-5 \%)$ in the tropics.

A time series of the monthly mean biases with respect to ozonesondes at Hohenpeissenberg and MOZAIC profiles at Frankfurt (Fig. 19) shows similar biases for both data sets. Large negative biases are seen at the beginning of the reanalysis, when the system was still adjusting and fewer ozone retrievals were available. From the end of 2004 until the end of 2007 , biases in the troposphere increase to up to $50 \%$ in the free troposphere and more near the surface. These drifts were traced back to the problem with the variational bias correction for ozone (see Sect. 2.3.2) which was resolved on 1 January 2008. Figure 19 shows that the biases in the free troposphere return to below $20 \%$ after January 2008. The large negative biases above $300 \mathrm{hPa}$ seen after March 2009 are a result of using NRT MLS data instead of the offline product, as already discussed above in Sect. 3.2.1.

\subsubsection{Surface ozone}

Surface ozone from the reanalysis is validated against data from the European Monitoring and Evaluation Programme (EMEP, http://www.emep.int/). Ozone measurements within EMEP are conducted with commercial UV monitors. An overview on the calibration/maintenance and data quality can be found on the EMEP website. A typical accuracy for a commercial UV instrument is about $1.5 \mathrm{ppbv}$. The precision is also close to $1.5 \mathrm{ppbv}$ for a $10 \mathrm{~s}$ measurement. Hourly mean EMEP observations of $\mathrm{O}_{3}$ from all available (close to surface level) EMEP stations (altitude $<600 \mathrm{~m}$ ) are used for the validation of the reanalysis simulations for the years 2003-2008. Only stations meeting the $75 \%$ availability threshold per day and per month are taken into account. Ground-level threehourly averages from the reanalysis are used to produce daily ozone averages, and the data are interpolated horizontally to the location of the EMEP stations. The EMEP surface ozone values and the interpolated surface reanalysis values are compared on a seasonal basis for the latitude bands of $30^{\circ} \mathrm{N}-$ $40^{\circ} \mathrm{N}$ (southern Europe), $40^{\circ} \mathrm{N}-50^{\circ} \mathrm{N}$ (central Europe) and $50^{\circ} \mathrm{N}-70^{\circ} \mathrm{N}$ (northern Europe), and the results are shown in Fig. 20. Over northern Europe, the reanalysis underestimates $\mathrm{O}_{3}$ levels during the first half of the year and overestimates $\mathrm{O}_{3}$ during the second half. This results in a negative bias (model minus observations) during winter and spring and a positive one during summer and autumn. Over central and southern Europe, the seasonal variability of ozone from the reanalysis agrees well with the observations, but a large negative bias is observed over central Europe during winter and spring. Over southern Europe the reanalysis systematically overpredicts ozone mixing ratios, with the highest discrepancies observed during summer and autumn. It should be noted that the reported absolute biases are significantly higher than the typical accuracy (1 ppbv) of the commercial UV monitoring instruments.

To better understand the above mentioned seasonal variability of the biases, the model simulations and the EMEP observations have been separated into daytime (12:0015:00 h) and night-time (00:00-03:00) data sets (Fig. 21). Over southern Europe, the overestimated reanalysis ozone (Fig. 20) coincides with positive daytime biases, which are largest between May and October. Over central Europe and despite the overall good agreement between the observations and the reanalysis during the warm period (March-October), large amplitudes were computed between the night-time and 

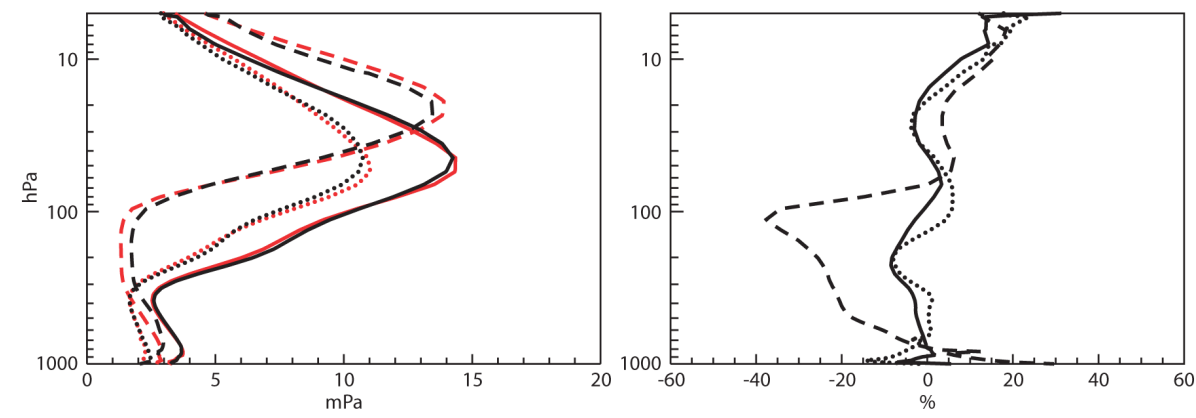

Fig. 16. Time mean ozone profiles (left) in mPa from the MACC reanalysis (red) and ozonesondes (black), and averaged ozone bias in $\%$ of MACC reanalysis minus ozonesondes (right) averaged over the period January 2003 to December 2010. Solid lines show means for the $\mathrm{NH}$ extratropical stations (i.e. north of $\left.30^{\circ} \mathrm{N}\right)$, dashed lines for tropical stations $\left(30^{\circ} \mathrm{S}-30^{\circ} \mathrm{N}\right)$, and dotted lines for $\mathrm{SH}$ extratropical stations (south of $30^{\circ} \mathrm{S}$ ).
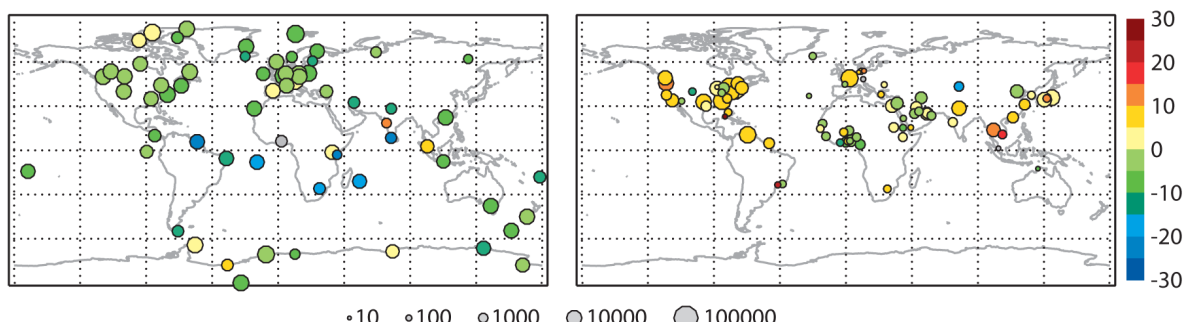

Fig. 17. Mean tropospheric ozone bias in \% of MACC reanalysis minus ozonesondes (left) and minus MOZAIC data (right) for the period January 2003 to December 2010, averaged between $200-1000 \mathrm{hPa}$. The diameter of the circles indicates the number of profiles over the respective stations. Grey circles depict biases of greater than $-30 \%$. Red indicates higher values of the field, blue lower values.

daytime biases. Specifically, during daytime the reanalysis strongly overpredicts ozone levels. During night-time on the other hand, the reanalysis has large negative biases. Lastly, over northern Europe, three well-defined temporal periods describe the biases. During the first period (JanuaryApril), the reanalysis systematically underestimates the surface ozone mixing ratios. The second period (April-August) is characterized by a progressive shift of the biases from negative to positive values, whilst for the third period (AugustDecember) the day and night biases are positive. The differences of the daytime and night-time biases are larger during the warmer periods when the highest amplitudes are observed. The reason for the diurnal variations of the biases is not understood at present and is being investigated further. It could be a result of using $\mathrm{NO}_{\mathrm{x}}$ emissions that do not have a diurnal cycle in the MOZART-3 CTM. During the day this would result in too-low emissions and hence too little $\mathrm{O}_{3}$ destruction; during the night emissions and hence $\mathrm{O}_{3}$ would be too large. Other factors could be issues with the vertical mixing between the free troposphere and the boundary layer or the fact that fewer observations are assimilated during the night when no UV data are available. Parrington et al. (2009) and Foret et al. (2009) assessed the impact of assimilating ozone data on surface ozone concentrations, and further stud- ies are necessary to determine the diurnal impact of the ozone assimilation on the surface ozone in the MACC system.

\subsubsection{Discussion of ozone analysis}

To put the magnitude of the ozone biases seen in the MACC reanalysis into perspective, MACC ozone is compared with ozone data from the ERA-Interim reanalysis (Dee et al., 2011). This data set is ECMWF's latest reanalysis product, and its ozone analysis fields have better quality than the ERA-40 ozone fields (Dragani, 2010, 2011). Figure 22 shows time series of monthly mean ozone bias profiles with respect to sondes from the reanalysis and ERA-Interim for a station at high northern latitudes (Alert), a tropical station (Natal), and an Antarctic station (South Pole). The MACC bias plots confirm what was already seen in Figs. 13 and 19. At all 3 stations the biases are larger during 2004 when no profile data were available, and after March 2009 when NRT MLS data were used. At Alert and South Pole the issues with the bias correction lead to larger biases in the troposphere and above $15 \mathrm{hPa}$ between August 2004 and December 2007. At all three stations tropospheric biases are reduced after 1 January 2008 when the problem with the variational bias correction for ozone was resolved. Figure 22 also shows that at South Pole the largest positive stratospheric biases are seen in Austral spring during the ozone hole season. Here, the 

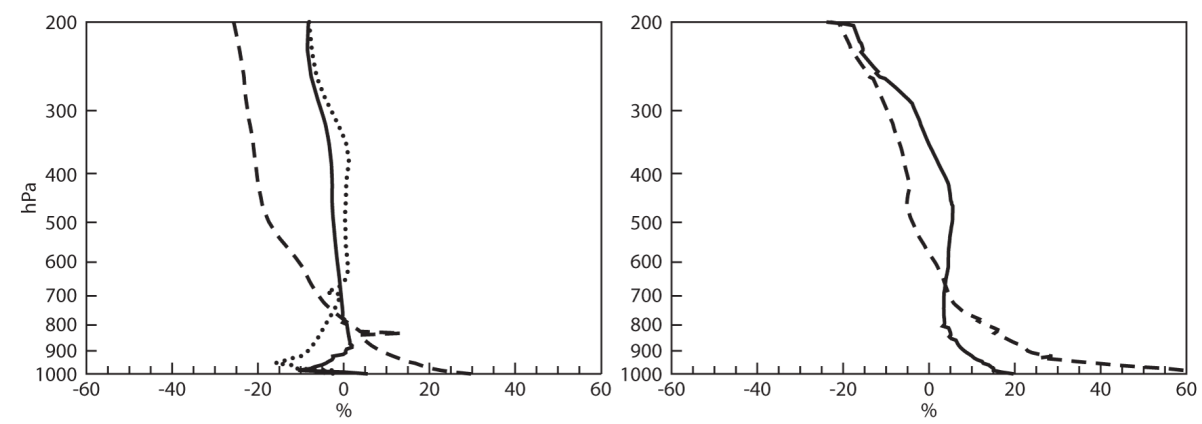

Fig. 18. Time mean ozone biases in \% from the MACC reanalysis minus sondes (left) and MACC minus MOZAIC data (right) averaged over the period January 2003 to December 2010. Solid lines show means for the NH extratropical stations (i.e. north of $30^{\circ} \mathrm{N}$ ), dashed lines for tropical stations $\left(30^{\circ} \mathrm{S}-30^{\circ} \mathrm{N}\right.$ ), and dotted lines for $\mathrm{SH}$ extratropical stations (south of $30^{\circ} \mathrm{S}$ ). Note that there are no MOZAIC flights in the $\mathrm{SH}$ in our database.
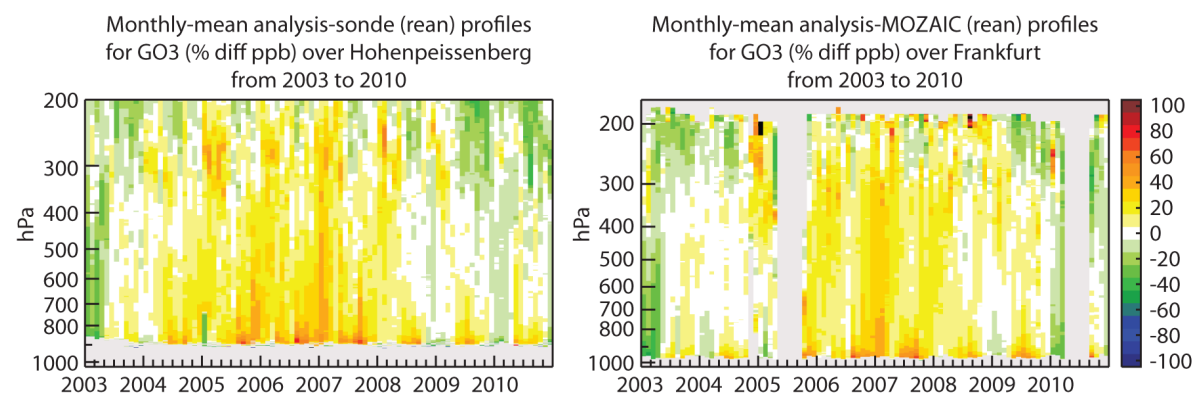

Fig. 19. Time series of monthly mean ozone biases (MACC reanalysis minus observations) with respect to ozonesondes at Hohenpeissenberg (left, $47.5^{\circ} \mathrm{N}, 11^{\circ} \mathrm{E}$ ) and MOZAIC profiles at Frankfurt Airport (right, 50.0 $\mathrm{N}, 8^{\circ} .6^{\circ} \mathrm{E}$ ) for the period January 2003 to December 2010 in $\%$. Red indicates higher values of the field, blue lower values.
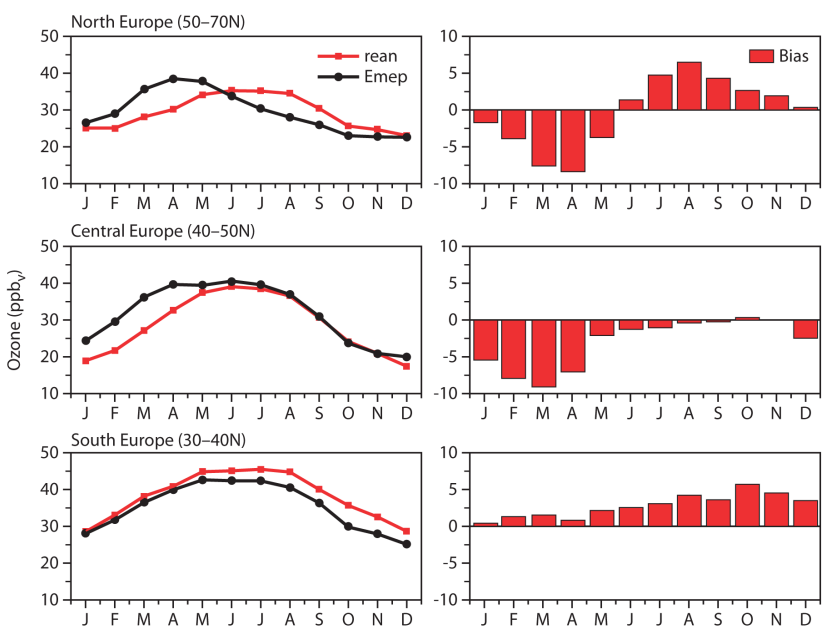

Fig. 20. Mean monthly annual variability during the period $2003-$ 2008 of the MACC reanalysis (red) and observations (black), and the absolute bias (red bars) over northern Europe (top panels, based on 72 monitoring stations), central Europe (middle, based on 27 stations) and southern Europe (bottom, based on 5 stations) in ppbv.

control run has a large bias and the ozone analysis can not completely remove this bias.

Figure 22 illustrates that the biases of ERA-Interim ozone are larger than those of the MACC reanalysis almost everywhere. This is particularly noticeable in the tropical troposphere, where biases greater than $100 \%$ are found near the surface in ERA-Interim. At Alert and South Pole, there are large changes in ERA-Interim between negative biases during winter/spring and positive biases during summer/autumn. In ERA-Interim ozone data are assimilated without bias correction and it is possible that a bias in one of the UV sensors can lead to a seasonally varying ozone bias with respect to sondes, depending on when data were available in the analysis. In ERA-Interim NRT MLS data have been used since November 2008, and like in the MACC reanalysis they lead to larger departures in the upper troposphere and lower stratosphere where the profile information is missing after this date. Also, the representation of the ozone hole is worse when NRT MLS data are used. The comparison shown in Fig. 22 illustrates that ozone from the MACC reanalysis has smaller errors than other available reanalysis products. 

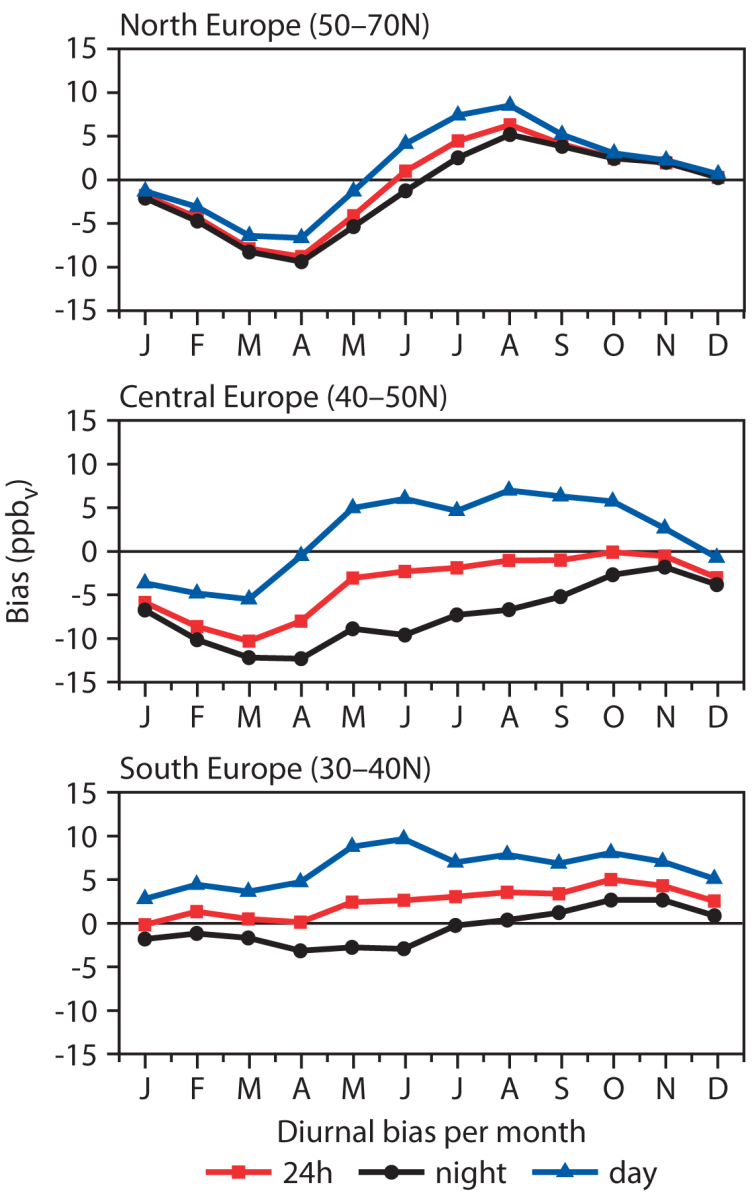

Fig. 21. Monthly mean variability (2003-2008) of the biases (MACC reanalysis minus EMEP) during daytime (blue line), nighttime (black line) and during the $24 \mathrm{~h}$ time period (red line) over northern Europe (top panel), central Europe (middle) and southern Europe (bottom).

\section{3 $\quad \mathrm{NO}_{2}$ analysis}

Tropospheric $\mathrm{NO}_{2}$ column retrievals from SCIAMACHY produced in the TEMIS project (Boersma et al., 2004) were assimilated in the MACC reanalysis. The largest uncertainties in the retrieval of tropospheric $\mathrm{NO}_{2}$ are due to errors in the description of clouds, albedo, a priori profile shape of the trace gas and aerosol description, and assumptions made for aerosol conditions. While some of the uncertainties such as those from the a priori profile shape are canceled in the assimilation by using the averaging kernels of the product, others have to be taken into account. Boersma et al. (2004) found that retrieval results were generally best for regions with strong $\mathrm{NO}_{2}$ sources or high surface albedo. Here, the errors of the retrieved tropospheric $\mathrm{NO}_{2}$ columns were of the order of 35-60\%. In clean areas with small background concentrations, the signal to noise ratio was very small and relative errors were very large. In the MACC reanalysis SCIAMACHY tropospheric $\mathrm{NO}_{2}$ columns V1.04 data were used until the end of June 2007, and V1.1 data after 11 September 2007 (see Table 1). Version 1.1 used an improved cloud algorithm in the retrieval of tropospheric trace gases, and as a result V1.1 tropospheric $\mathrm{NO}_{2}$ columns were lower than those from V1.04, in particular over heavily polluted areas with low clouds (Wang et al., 2008). This data change however did not have a large impact on the $\mathrm{NO}_{2}$ reanalysis fields (see Fig. 26 below).

SCIAMACHY has a local overpass time of 10:00. A dedicated observation operator was used to convert the model $\mathrm{NO}_{\mathrm{x}}$ to $\mathrm{NO}_{2}$ in the reanalysis at the time and location of the observations (see also Sect. 2.2.1). This is important, because $\mathrm{NO}_{2}$ has an atmospheric lifetime in the boundary layer of the order of an hour in summer and about one day in winter, and shows large spatial and temporal variability around source areas. Figure 23 shows seasonal mean tropospheric $\mathrm{NO}_{2}$ columns from the MACC reanalysis. The largest tropospheric $\mathrm{NO}_{2}$ columns are found in the industrial areas of the NH, with maxima during DJF over Europe, China and the eastern US. This is the result of seasonal variations in the photochemical lifetime of $\mathrm{NO}_{2}$ and increased anthropogenic emissions during this season. In the $\mathrm{SH}$ there are some hot spots with high $\mathrm{NO}_{2}$ columns from fossil fuel emissions over the urban areas and coal fired power plants of South Africa, and over cities in south-east Australia. In the tropics, the largest $\mathrm{NO}_{2}$ values come from biomass burning events during the local dry season. This is during DJF in northern Africa and during JJA and SON in Africa south of the equator. Over South America the strongest $\mathrm{NO}_{2}$ signal is seen in SON when biomass burning activity is strongest here. Values in this region are lower than over Africa as a result of the lower $\mathrm{NO}_{\mathrm{x}} / \mathrm{CO}$ emission ratio for tropical forest fires compared to Savannah fires. Over Indonesia and north-west Australia, the biomass burning signal is strongest during SON. The seasonality of the $\mathrm{NO}_{2}$ signal from biomass burning is in good agreement with the $\mathrm{CO}$ signal (see Fig. 3).

To validate the tropospheric $\mathrm{NO}_{2}$ fields from the MACC reanalysis, a comparison was made with SCIAMACHY tropospheric column data retrieved by IUP-Bremen. This data set is different from the TEMIS SCIAMACHY data that are assimilated in the reanalysis (see Table 1). Even though the two SCIAMACHY retrievals are based on the same level 1 spectral irradiance data, the retrieval products are completely independent, from the spectral fit to the assumptions made on the a priori used for the air mass factor calculations. While this is not ideal in terms of having fully independent validation data, it can provide a critical evaluation of the model performance on a global scale. The IUP retrieval of tropospheric $\mathrm{NO}_{2}$ columns from SCIAMACHY measurements is performed in several steps, starting with the retrieval of $\mathrm{NO}_{2}$ slant column (SC) with the DOAS (differential optical absorption spectroscopy) technique in the $425-450 \mathrm{~nm}$ wavelength windows. The tropospheric SC is calculated by subtracting the stratospheric contribution from the total columns retrieved, assuming that the region over the Pacific $\left(180^{\circ} \mathrm{E}-\right.$ 

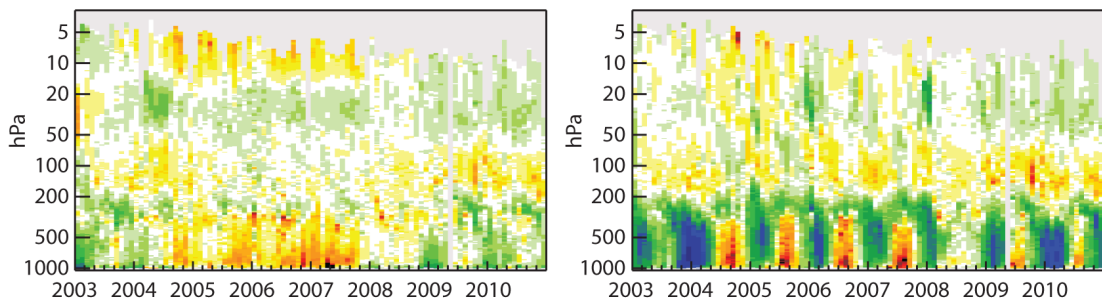

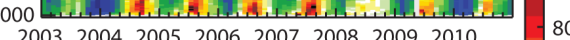
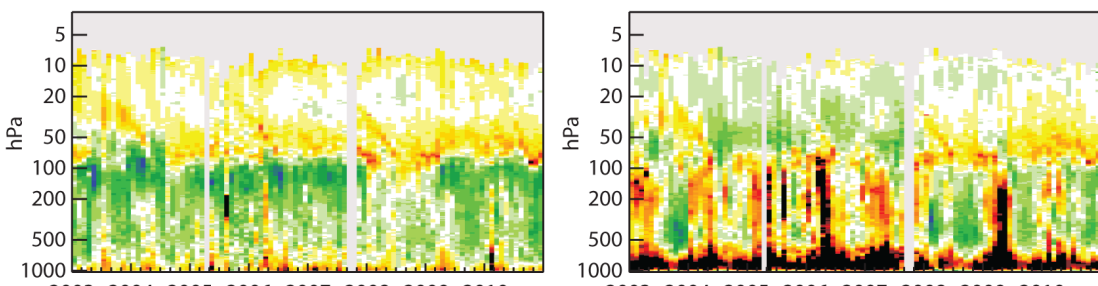

20032004200520062007200820092010
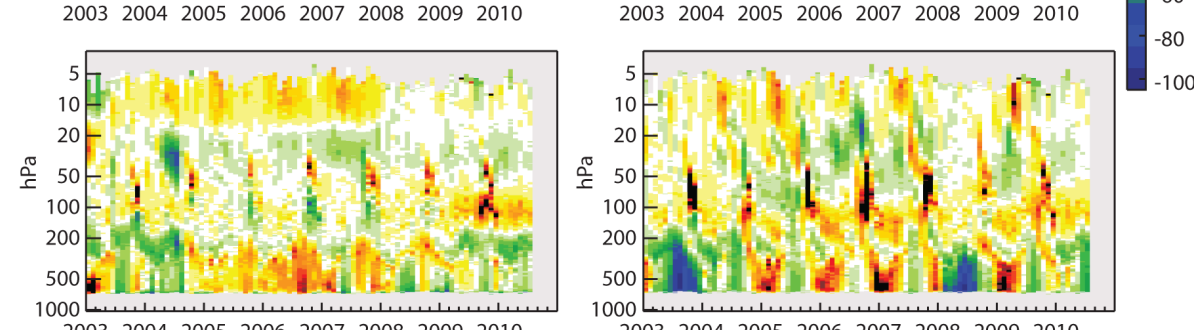

20032004200520062007200820092010

20032004200520062007200820092010

Fig. 22. Time series of monthly mean ozone bias profiles from the MACC reanalysis (left panels) and ERA-Interim (right panels) with respect to ozonesondes at Alert $\left(82.5^{\circ} \mathrm{N}, 62.3^{\circ} \mathrm{W}\right.$, top), Natal $\left(5.5^{\circ} \mathrm{S}, 35.3^{\circ} \mathrm{W}\right.$, middle) and the South Pole (bottom) for the period 2003 to 2010 in \%. Red indicates higher values of the field, blue lower values.

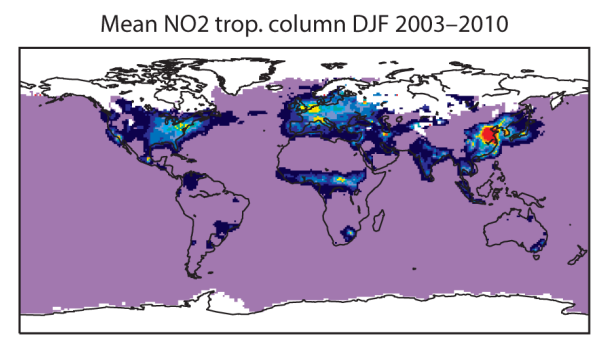

Mean NO2 trop. column JJA 2003-2010

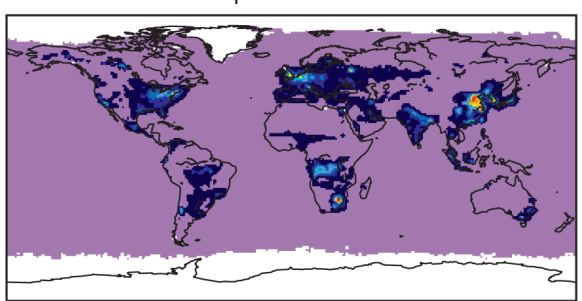

Mean NO2 trop. column MAM 2003-2010

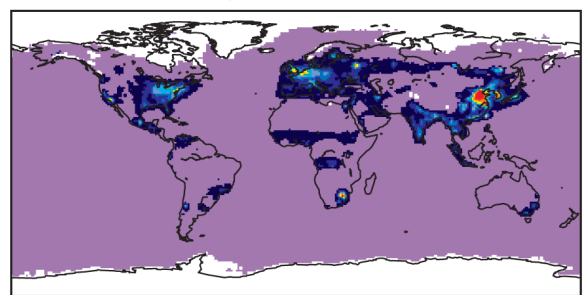

Mean NO2 trop. column SON 2003-2010

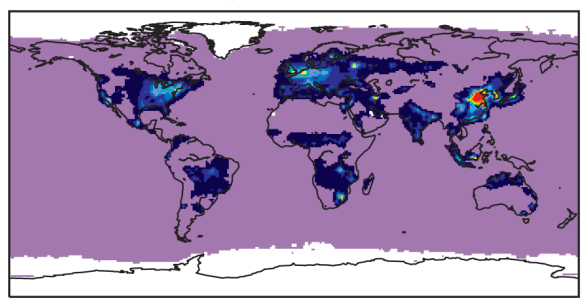

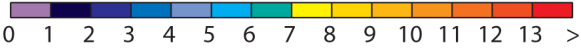

Fig. 23. Seasonal mean tropospheric $\mathrm{NO}_{2}$ columns from the MACC reanalysis in $10^{15}$ molecules $\mathrm{cm}^{-2}$ for DJF (top left), MAM (top right), JJA (bottom left) and SON (bottom right), averaged over the years 2003 to 2010. The analysis data were sampled to match the coverage and overpass time of the SCIAMACHY data. Red indicates higher values of the field, blue lower values.

$220^{\circ} \mathrm{E}$ ) is clean in the lower atmosphere. Airmass factors determined from radiative transfer calculations are used to convert the tropospheric slant columns to vertical columns. As a rough estimate, systematic uncertainties in polluted re- gions are of the order of 30-50\%. Further details regarding the retrieval can be found, for example, in Richter and Burrows (2002) and Richter et al. (2005). $\mathrm{NO}_{2}$ tropospheric columns are only determined for clear sky pixels, i.e. for 

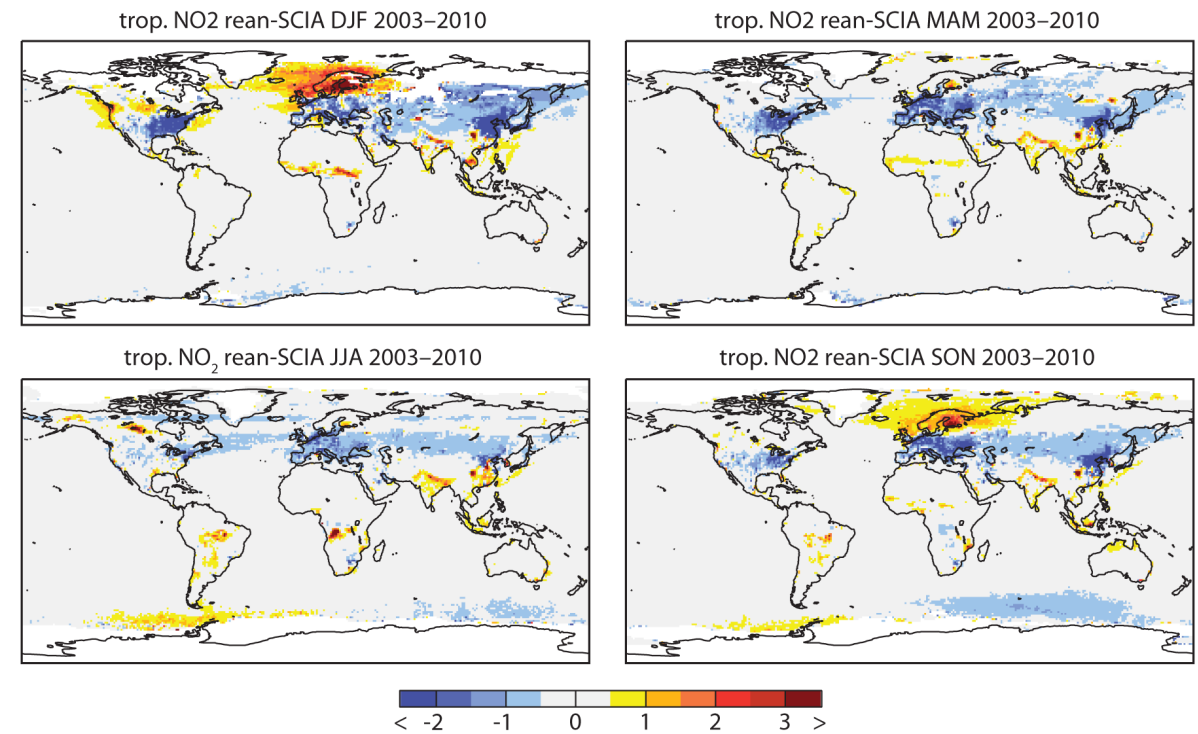

Fig. 24. Seasonal mean differences between tropospheric $\mathrm{NO}_{2}$ vertical columns from the MACC reanalysis and IUP-SCIAMACHY data in $10^{15}$ molecules $\mathrm{cm}^{-2}$ for DJF (top left), MAM (top right), JJA (bottom left) and SON (bottom right), averaged over the years 2003 to 2010. For proper comparison with the measurements, the reference sector was also subtracted from the reanalysis data. Red indicates higher values of the field, blue lower values.

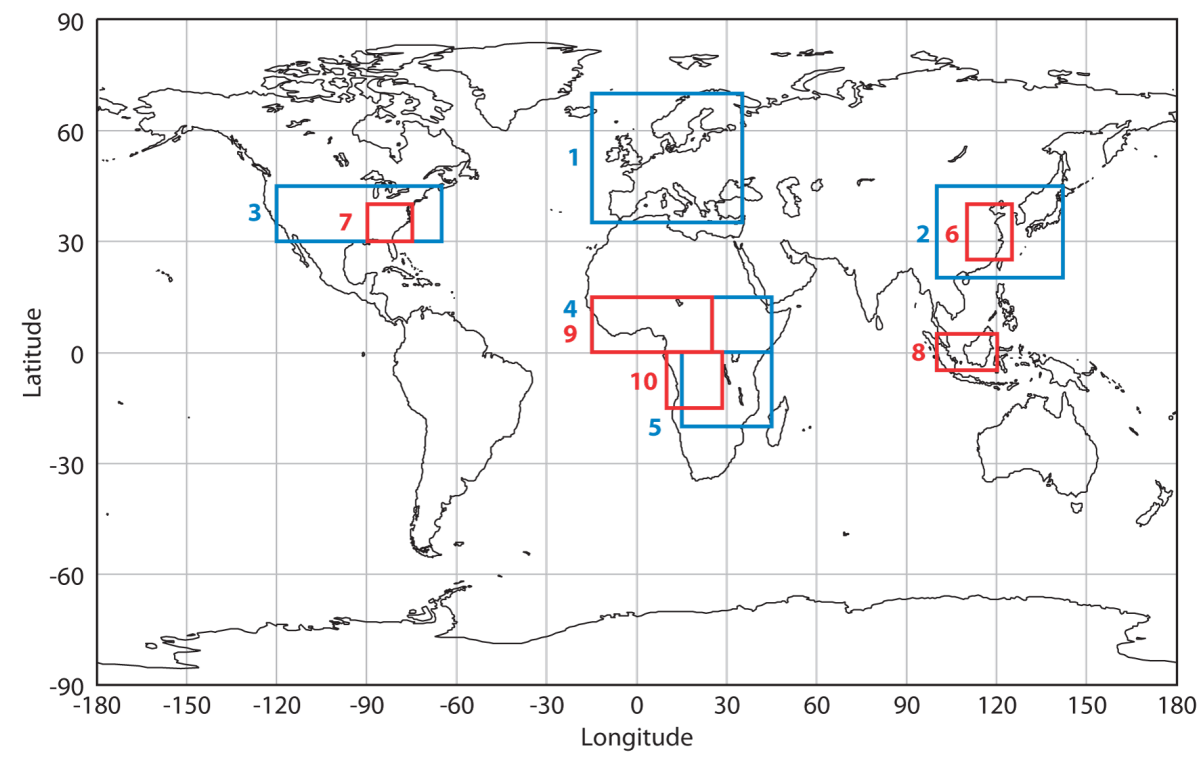

Fig. 25. Regions used for validation of $\mathrm{MACC} \mathrm{NO}_{2}$ data (blue) and MACC HCHO data (red) against IUP-SCIAMACHY data. $\mathrm{NO}_{2}$ regions: (1) Europe, (2) east Asia, (3) US, (4) northern Africa, and (5) southern Africa. HCHO regions: (6) China, (7) eastern US, (8) Indonesia, (9) northern Africa, and (10) southern Africa.

cloud fractions smaller than $20 \%$ according to the cloud cover data from the FRESCO database (Koelemeijer et al., 2001; Wang et al., 2008). For the comparison with the IUP satellite retrievals, the model was sampled at the time and location of the SCIAMACHY overpass and the satellite data were averaged to the model spatial resolution.

Figure 24 shows the seasonal mean differences between tropospheric $\mathrm{NO}_{2}$ columns from the MACC reanalysis and
IUP-SCIAMACHY. As the satellite data are relative to the clean Pacific reference sector, the same correction has been applied to the model data. These plots show that the largest differences are found over the urban areas of the $\mathrm{NH}$, where the MACC reanalysis underestimates $\mathrm{NO}_{2}$ with respect to the SCIAMACHY data. The largest negative differences in the NH are found in DJF over east Asia and the eastern US. The best agreement for the polluted areas of the $\mathrm{NH}$ is seen 
over the US in JJA. Negative differences are also seen for $\mathrm{NO}_{2}$ hotspots in South Africa. Several reasons might explain the low bias of the reanalysis $\mathrm{NO}_{2}$ with respect to the IUPSCIAMACHY data over the urban areas of the NH. Firstly, the anthropogenic $\mathrm{NO}_{\mathrm{x}}$ emissions from the MACCity data set could be too low, but considering the observed downward trend in $\mathrm{NO}_{\mathrm{x}}$ emissions (van der $\mathrm{A}$ et al., 2008), this is unlikely. Secondly, there is no daily cycle in emissions applied in MOZART-3, which may result in underestimation of emissions at 10:00, i.e. during daytime and shortly after the rush hour. Thirdly, because of the short lifetime the information brought into the system by assimilating SCIAMACHY data is lost quickly, and the impact of the $\mathrm{NO}_{2}$ assimilation is actually small. Finally, with the relatively low resolution of MOZART-3, the maximum emissions in urban areas might not be modelled correctly. Over northern Europe the reanalysis is higher than the IUP-SCIAMACHY data in DJF and SON. This might be related to a problem in lifetime leading to too much transport of pollution into these areas.

Over tropical biomass burning regions, the reanalysis $\mathrm{NO}_{2}$ columns are higher than the IUP-SCIAMACHY data, for example in northern Africa during DJF, in southern Africa in JJA, and in South America in JJA and SON. Over Indonesia the reanalysis generally overestimates the $\mathrm{NO}_{2}$ columns relative to the data, with the largest deviations in SON. Over north-west Australia the differences are also positive in SON.

Other interesting aspects are clear spots of positive differences for the boreal fires (e.g. Asia in MAM, North America in JJA) that are captured in the reanalysis but not seen by the satellite. This could be related to a too-large $\mathrm{NO}_{\mathrm{x}} / \mathrm{CO}$ emission ratio used for fires in boreal forests. The reanalysis background concentrations over clean areas agree to within $\pm 0.5 \times 10^{15}$ molecules $\mathrm{cm}^{-2}$ with IUP-SCIAMACHY data, which is close to the detection limit of the instrument.

Next, time series of area-averaged monthly mean tropospheric $\mathrm{NO}_{2}$ from the reanalysis and from IUPSCIAMACHY data are compared. The areas used for the $\mathrm{NO}_{2}$ comparison are shown in blue in Fig. 25. Only land points are used to calculate the monthly area averages. The MACCity emissions have a positive trend for $\mathrm{NO}_{\mathrm{x}}$ emissions over China, and negative trends over western Europe and the US (Granier et al., 2011a).

Figure 26 shows the time series for the polluted regions of the NH for the reanalysis, the control run and the IUPSCIAMACHY data. The plots show the impact of the $\mathrm{NO}_{2}$ assimilation is small, because reanalysis and control run are very similar. This can have several reasons. First, the $\mathrm{NO}_{2}$ data have larger observation errors than the $\mathrm{CO}$ or $\mathrm{O}_{3}$ data, and are therefore given less weight in the analysis. Secondly, because of the short lifetime of $\mathrm{NO}_{2}$ and the fact that $\mathrm{NO}_{2}$ data are only assimilated once per day, the impact of the analysis is lost again quickly. A larger impact might be obtained by assimilating data from an additional instrument with a different overpass time (e.g. $\mathrm{NO}_{2}$ from OMI, which has a local overpass time of 13:40). Figure 26 shows that the sim- ulation of tropospheric $\mathrm{NO}_{2}$ in the reanalysis has a realistic seasonal cycle with maxima during the winter months and minima during the summer. There is good agreement during the summer, but winter values are too low. Particularly, over east Asia there is an underestimation of tropospheric $\mathrm{NO}_{2}$ by about a factor of 2 during winter in the reanalysis, as already seen in Fig. 24. For Europe and the US, the agreement between the IUP-SCIAMACHY data and the reanalysis is better. Considering the low resolution of the MOZART-3 $\mathrm{CTM}$, maximum $\mathrm{NO}_{\mathrm{x}}$ emissions in urban areas are not modelled adequately and at least some of the differences seen in Fig. 26 are likely to be representativeness errors.

Figure 27 shows time series of monthly mean tropospheric $\mathrm{NO}_{2}$ columns from the reanalysis and IUP-SCIAMACHY for the biomass burning areas of northern and southern Africa. Again the differences between the reanalysis and the control run are negligible. The figure shows that the reanalysis has the right seasonality with maximum values in northern Africa during DJF and in southern Africa during June to September. However, the reanalysis overestimates the tropospheric $\mathrm{NO}_{2}$ columns during the biomass burning seasons, as already seen in Fig. 24. The overestimation during the biomass burning season could again be related to a too-large $\mathrm{NO}_{\mathrm{x}}$ emission factor used for fires.

The correlation between the global and seasonally averaged reanalysis $\mathrm{NO}_{2}$ and the IUP-SCIAMACHY data (over all surfaces) averaged over the years 2003 to 2010 is 0.83 in DJF, 0.87 in MAM, 0.82 in JJA and 0.84 in SON, indicating a good spatial agreement between the reanalysis and the satellite retrievals. Table 2 shows correlations between the seasonal trends of reanalysis and IUP-SCIAMACHY data for the five $\mathrm{NO}_{2}$ regions (data considered only from land grid boxes). The high correlation over east Asia shows that the reanalysis captures the seasonal $\mathrm{NO}_{2}$ trend well, despite the wintertime biases.

Table 3 summarizes the seasonal mean biases between IUP-SCIAMACHY $\mathrm{NO}_{2}$ data and the reanalysis fields for the five regions discussed above. For this table daily differences between the reanalysis and SCIAMACHY were calculated over land and then averaged over the years 2003-2010 for the corresponding months and regions. The table confirms that the largest negative biases can be seen over the industrial areas of the NH, with maxima during the winter months. The biases in the African biomass burning areas are smaller. Over northern Africa the bias is positive apart from JJA when it is small and negative. In southern Africa biases are largest and positive in JJA and small and negative in the other seasons.

Figure 28 shows seasonal mean zonal average $\mathrm{NO}_{\mathrm{x}}$ altitude cross sections from the MACC reanalysis to illustrate the vertical structure of the $\mathrm{NO}_{\mathrm{x}}$ field. $\mathrm{NO}_{\mathrm{x}}$ concentrations are largest near the surface and fall off rapidly with height. This illustrates the dominating importance of the emissions for the $\mathrm{NO}_{\mathrm{x}}$ field. 
Table 2. Correlation between the seasonal trends of the monthly averaged MACC reanalysis and IUP-SCIAMACHY NO 2 data over land.

\begin{tabular}{lcccccc}
\hline Region & World & Europe & east Asia & US & northern Africa & southern Africa \\
\hline Correlation & 0.89 & 0.72 & 0.96 & 0.85 & 0.86 & 0.91 \\
\hline
\end{tabular}

Table 3. Seasonal mean biases and rms errors in $10^{15}$ molecules $\mathrm{cm}^{-2}$ of MACC reanalysis and IUP-SCIAMACHY NO 2 averaged over the years 2003 to 2010 for the 5 regions illustrated above. Only land points were used in the calculations.

\begin{tabular}{lrrrrrrrr}
\hline & \multicolumn{2}{c}{ DJF } & \multicolumn{2}{c}{ MAM } & \multicolumn{2}{c}{ JJA } & \multicolumn{2}{c}{ SON } \\
& Bias & RMS & Bias & RMS & Bias & RMS & Bias & RMS \\
\hline east Asia & -4.10 & 6.91 & -1.12 & 2.60 & -0.01 & 1.34 & -1.80 & 3.58 \\
Europe & -0.41 & 3.09 & -0.62 & 1.34 & -0.34 & 0.88 & -0.05 & 1.73 \\
US & -1.12 & 2.70 & -0.61 & 1.22 & -0.05 & 0.66 & -0.22 & 0.90 \\
northern Africa & 0.53 & 0.67 & 0.20 & 0.40 & -0.01 & 0.22 & 0.16 & 0.33 \\
southern Africa & -0.02 & 0.11 & -0.02 & 0.21 & 0.53 & 0.86 & -0.01 & 0.47 \\
\hline
\end{tabular}
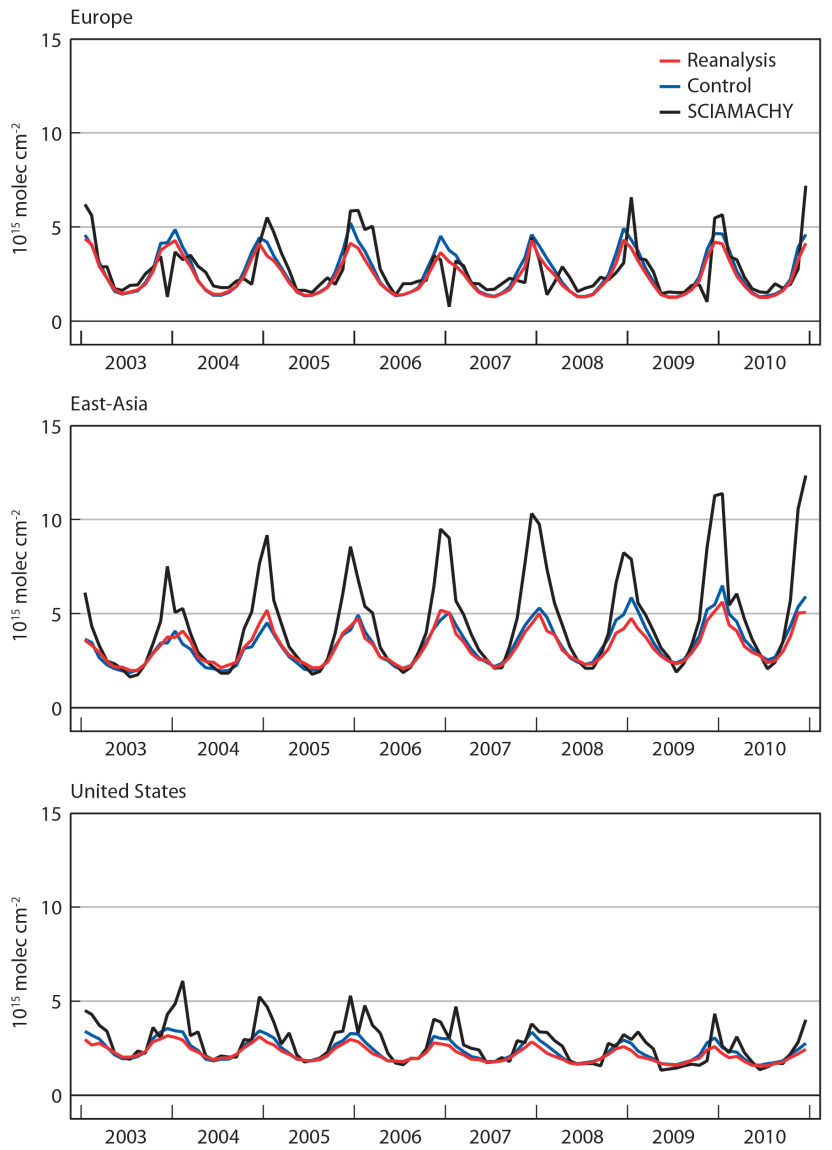

Fig. 26. Time series of monthly mean area-averaged tropospheric $\mathrm{NO}_{2}$ columns in $10^{15}$ molecules $\mathrm{cm}^{-2}$ from the MACC reanalysis (red), the control run (blue) and IUP-SCIAMACHY data (black) for the period 2003 to 2010 for Europe (top), east Asia (middle) and the US (bottom). Only land points were used in these calculations.
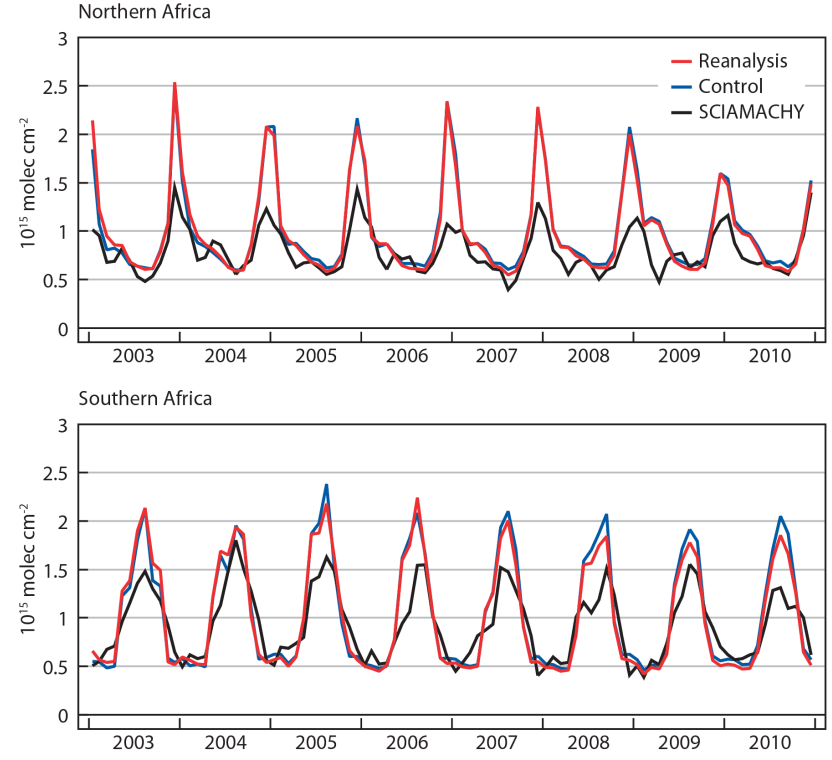

Fig. 27. Time series of monthly mean area-averaged tropospheric $\mathrm{NO}_{2}$ columns in $10^{15}$ molecules $\mathrm{cm}^{-2}$ from the MACC reanalysis (red), the control run (blue) and from IUP-SCIAMACHY data (black) for the period 2003 to 2010 for northern Africa (top) and southern Africa (bottom). Only land points were used in these calculations.

\subsection{HCHO analysis}

HCHO data are not assimilated in the MACC reanalysis because the data quality of individual satellite retrievals is not sufficient. Monthly mean observations generally have a total error of $20-40 \%$, but individual observations can have much larger errors (De Smedt et al., 2008). Over Europe, for example, the mean HCHO column is smaller than the random error of SCIAMACHY observations, which does not favour assimilating individual observations. Hence, the $\mathrm{HCHO}$ reanalysis 

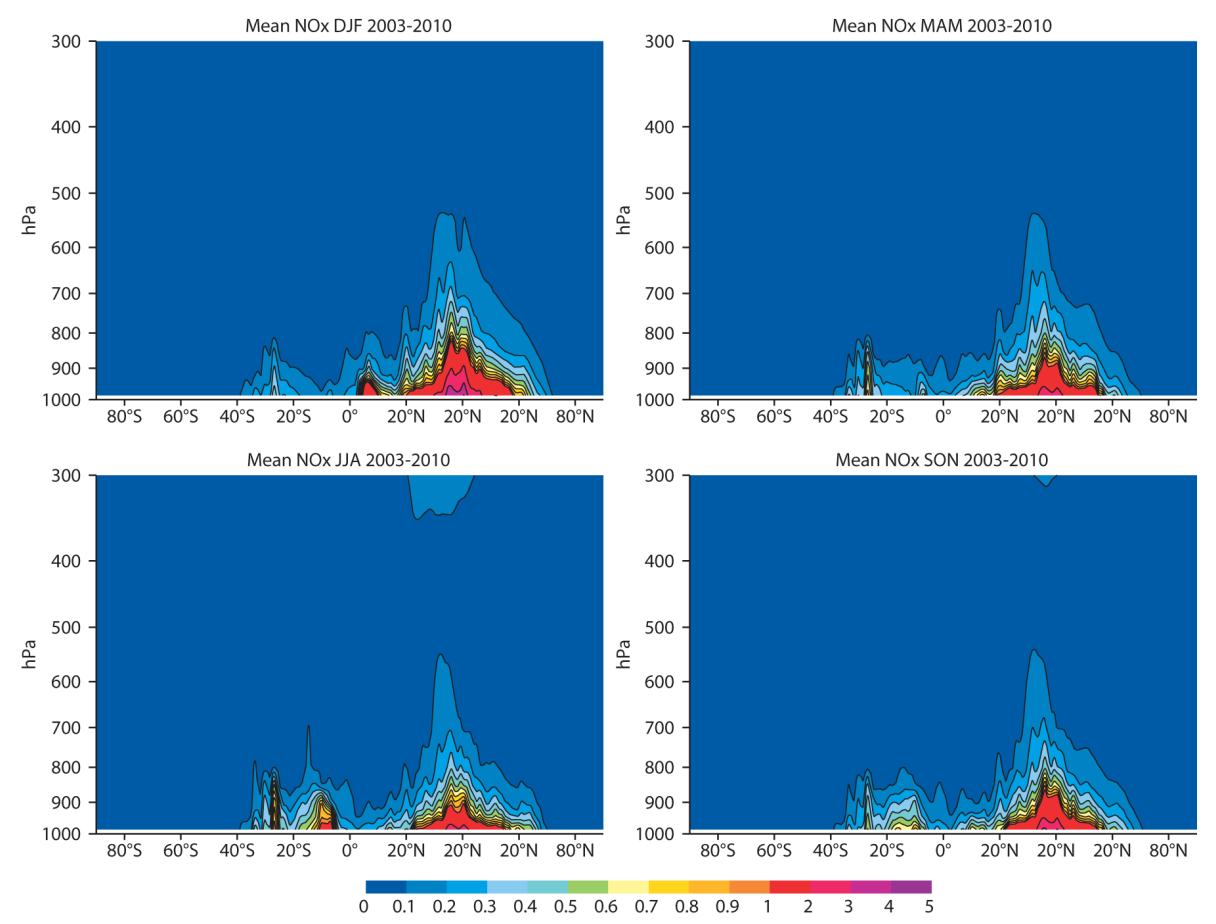

Fig. 28. Seasonal mean zonal average $\mathrm{NO}_{\mathrm{x}}$ cross sections from the MACC reanalysis in ppb for DJF (top left), MAM (top right), JJA (bottom left) and SON (bottom right), averaged over the years 2003 to 2010. Red indicates higher values of the field, blue lower values.

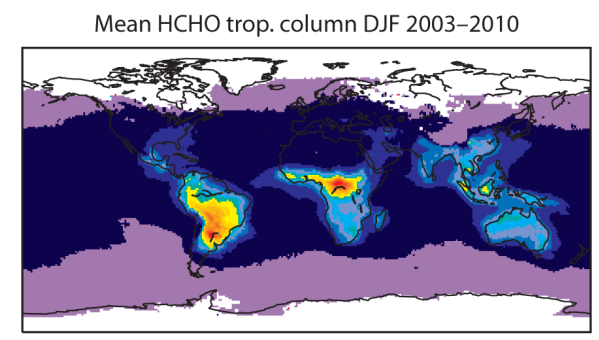

Mean HCHO trop. column JJA 2003-2010

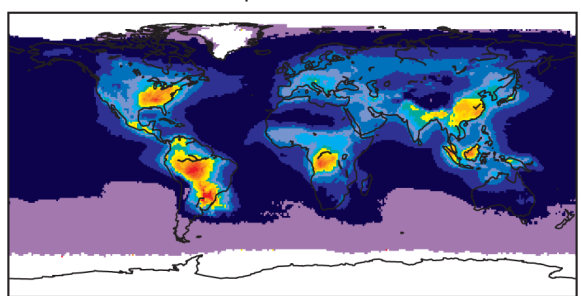

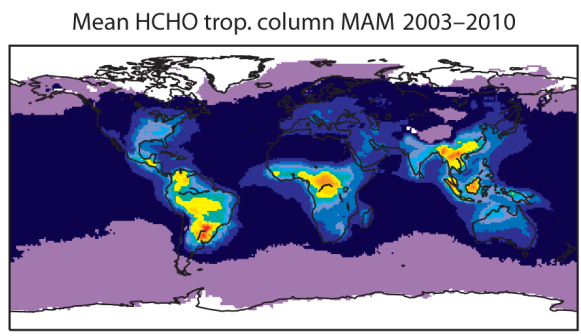

Mean HCHO trop. column SON 2003-2010

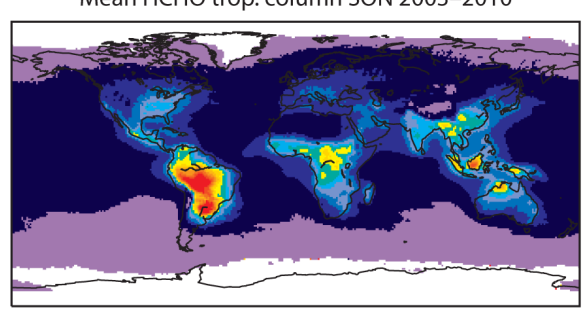

\begin{tabular}{llllllllll|l|l|l|l|l|l|l|l|l}
\hline 0 & 2 & 4 & 6 & 8 & 10 & 12 & 14 & 16 & 18 & 20 & 22 & 24 & 26
\end{tabular}

Fig. 29. Seasonal mean tropospheric HCHO columns from the MACC reanalysis in $10^{15}$ molecules $\mathrm{cm}^{-2}$ for DJF (top left), MAM (top right), JJA (bottom left) and SON (bottom right), averaged over the years 2003 to 2010. The analysis data were sampled to match the coverage and overpass time of the SCIAMACHY data. Red indicates higher values of the field, blue lower values.

fields are entirely determined by the MOZART-3 chemistry, the MACCity emissions and the atmospheric transport.

Figure 29 shows seasonal mean tropospheric HCHO columns from the MACC reanalysis. The largest $\mathrm{HCHO}$ columns are found in the tropics and reflect the regions of high biogenic VOC emissions and biomass burning. High values are also found over the south-eastern US in JJA and are indicative of the oxidation of isoprene emitted during the growing season in the summer. Values over Europe are much lower but also peak in JJA. Figure 29 agrees well with the 


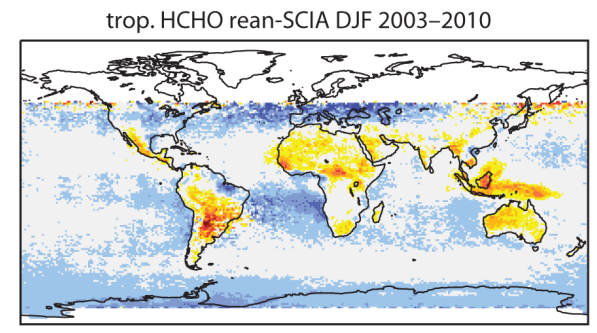

trop. HCHO rean-SCIA JJA 2003-2010

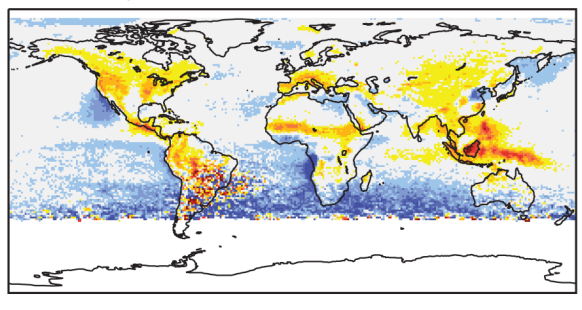

$<$\begin{tabular}{rr}
\hline & -8
\end{tabular}

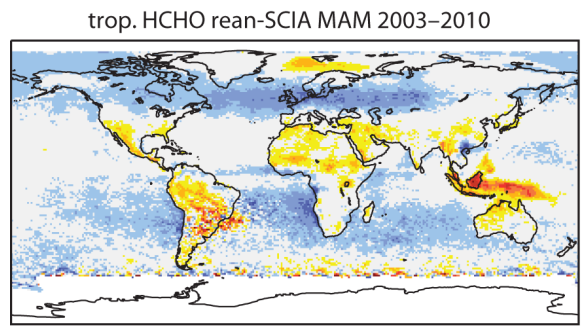

trop. HCHO rean-SCIA SON 2003-2010

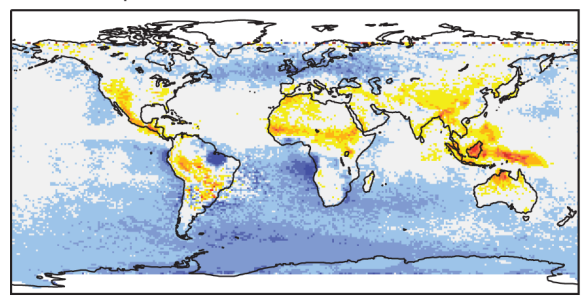

$12>$

Fig. 30. Seasonal mean differences between tropospheric HCHO columns from the MACC reanalysis and IUP-SCIAMACHY data in $10^{15}$ molecules $\mathrm{cm}^{-2}$ for DJF (top left), MAM (top right), JJA (bottom left) and SON (bottom right), averaged over the years 2003 to 2010. Red indicates higher values of the field, blue lower values.

Table 4. Correlation between the seasonal cycles of monthly averaged MACC reanalysis and IUP-SCIAMACHY HCHO data over land.

\begin{tabular}{lcccccc}
\hline Region & World & China & US & Indonesia & northern Africa & southern Africa \\
\hline Correlation & 0.24 & 0.85 & 0.81 & 0.69 & 0.54 & 0.84 \\
\hline
\end{tabular}

global maps shown in De Smedt et al. (2008). Over South America, the maximum $\mathrm{HCHO}$ values are seen during the fire season (August to November). In Africa, north of the equator, maximum values are found during the main fire season in DJF. South of the equator, the maximum values are observed in JJA. Over south east Asia the largest HCHO concentrations occur during MAM and JJA, and are likely to be associated with biogenic VOC emissions. For the region of Indonesia, the $\mathrm{HCHO}$ concentrations are always high, with a minimum observed during DJF. Over northern Australia $\mathrm{HCHO}$ concentrations are largest during the main growing season SON and DJF.

To validate the tropospheric $\mathrm{HCHO}$ columns from the reanalysis, they are compared with SCIAMACHY HCHO data retrieved by IUP-Bremen. The IUP retrieval of HCHO columns follows a similar approach as the $\mathrm{NO}_{2}$ method described in the previous section, using also the approach of reference sector to correct for instrumental drift and appropriate airmass factors to convert the slant to vertical columns. To account for the tropospheric HCHO amount present over the region between $180-200^{\circ} \mathrm{E}$ used for normalization, a mean value of $3.5 \times 10^{15}$ molecules $\mathrm{cm}^{-2}$ is added. Further details on the retrieval can be found in Wittrock (2006) and Wittrock et al. (2006). The total error on the monthly and regionally averaged data is between $20-40 \%$, and the detection limit is $2 \times 10^{15}$ molecules $\mathrm{cm}^{-2}$. The uncertainty in the mean of the observations is estimated to be of the order of $10^{16}$ molecules $\mathrm{cm}^{-2}$ (Wittrock, 2006). However, for HCHO hotspots, both the absolute values and the seasonality can be retrieved with confidence. Figure 30 shows the seasonal mean differences between IUP HCHO tropospheric columns and the reanalysis fields. The figure shows that there are limitations with the satellite retrievals at low solar elevations, which lead to large differences and large scatter in the $\mathrm{NH}$ during DJF and in the SH during JJA. The difference plots also show scatter over the area of the South Atlantic anomaly in JJA. This localized discrepancy is due to an artefact in the observations, because here the SCIAMACHY instrument is exposed to high energy solar particles, leading to a reduced signal to noise ratio and a large scatter in the data. Figure 30 shows that the reanalysis overestimates the $\mathrm{HCHO}$ tropospheric columns with respect to SCIAMACHY in regions with high biogenic emissions and biomass burning. This is the case in the eastern US, Europe and China during JJA, and in northern Africa, South America and Indonesia throughout the year. In southern Africa the seasonal mean differences between the IUP-SCIAMACHY data and the reanalysis are small.

The plots indicate that the reanalysis underestimates $\mathrm{HCHO}$ for background concentrations over the oceans, 
Table 5. Seasonal mean biases and rms errors in $10^{15}$ molecules $\mathrm{cm}^{-2}$ for MACC reanalysis and IUP-SCIAMACHY HCHO averaged over the years 2003 to 2010 for the 5 regions discussed above. Only land points were used in the calculation.

\begin{tabular}{lrrrrrrrr}
\hline \multirow{2}{*}{ HCHO } & \multicolumn{2}{c}{ DJF } & \multicolumn{2}{c}{ MAM } & \multicolumn{2}{c}{ JJA } & \multicolumn{2}{c}{ SON } \\
& Bias & RMS & Bias & RMS & Bias & RMS & Bias & RMS \\
\hline China & 0.50 & 1.31 & 1.02 & 1.27 & -1.23 & 3.74 & 0.03 & 1.64 \\
eastern US & -1.90 & 1.48 & 1.43 & 1.25 & 2.25 & 1.70 & 1.55 & 1.09 \\
Indonesia & 5.01 & 2.34 & 7.83 & 2.55 & 8.57 & 2.81 & 6.29 & 2.05 \\
northern Africa & 2.56 & 3.15 & 1.00 & 2.54 & 0.23 & 2.94 & 1.40 & 2.73 \\
southern Africa & -0.42 & 1.22 & -0.43 & 2.26 & -1.24 & 4.12 & -1.80 & 2.38 \\
\hline
\end{tabular}
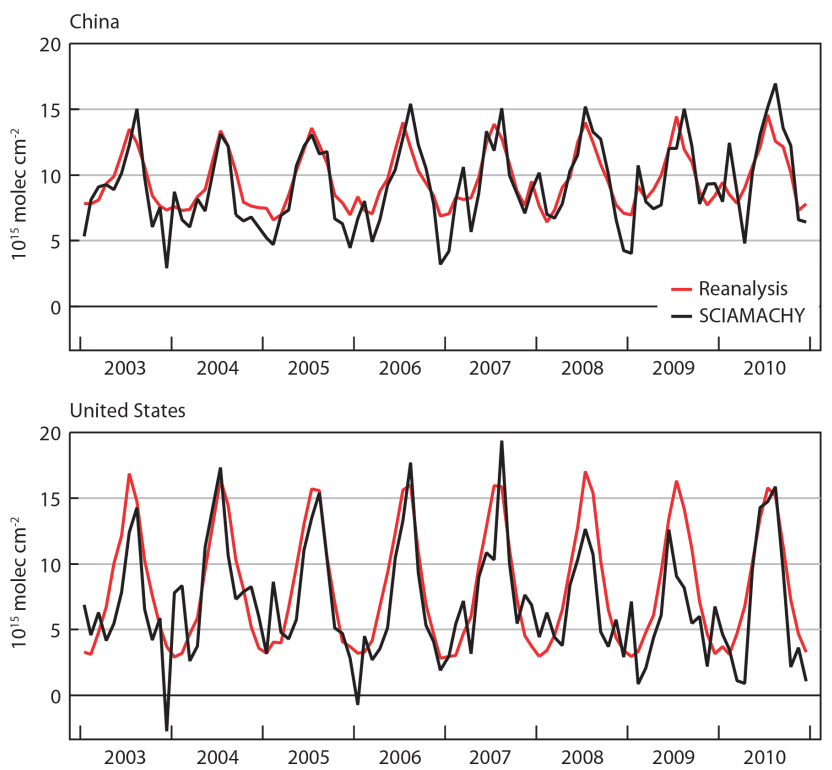

Fig. 31. Time series of monthly mean area-averaged tropospheric $\mathrm{HCHO}$ columns in $10^{15}$ molecules $\mathrm{cm}^{-2}$ from the MACC reanalysis (red) and IUP-SCIAMACHY (black) for China (top) and the eastern US (bottom). Only land points were used in these calculations.

where oxidation of methane is the main source of HCHO. This could point to a problem with the retrieval over sea, but the $\mathrm{HCHO}$ values here are close to the detection limit of the instrument, and the differences are hence not very meaningful.

Next, time series of monthly mean tropospheric $\mathrm{HCHO}$ from the reanalysis and IUP-SCIAMACHY data are compared. The regions used for the HCHO comparison are shown in red in Fig. 25 and focus on areas with a strong HCHO signal. Only land points are used to calculate the monthly area averages. The differences between the reanalysis and the control are very small, which was to be expected because no $\mathrm{HCHO}$ data were assimilated in the MACC reanalysis. For this reason the control run is not shown in the time series plots below. Figure 31 shows time series over China and the eastern US, regions dominated by biogenic emissions with some anthropogenic input. Figure 32 shows time series for northern Africa, southern Africa, and Indonesia, i.e. regions with biogenic sources and biomass burning. The seasonality and magnitude is well captured for China and the eastern US. In the biomass burning areas of northern Africa, the reanalysis overestimates $\mathrm{HCHO}$ during the main fire season, but the agreement between reanalysis and data in southern Africa is good. The largest differences are seen over Indonesia where the reanalysis is almost constantly higher than the satellite data by at least $5 \times 10^{15}$ molecules $\mathrm{cm}^{-2}$. However, during the Indonesian fires in October 2006 the reanalysis and the satellite data show good agreement, capturing the very high values of $\mathrm{HCHO}$ registered for this month.

The regional correlations between the monthly mean reanalysis time series and the IUP-SCIAMACHY data are shown in Table 5 (data considered only from land grid boxes). They are low for the world, confirming that a meaningful statement can only be made for regions with large HCHO concentrations. In the five regions discussed above, the correlations are lowest over Indonesia and northern Africa, confirming what was seen in Fig. 32.

Figure 33 shows seasonal mean zonal average cross sections of $\mathrm{HCHO}$ from the reanalysis. It shows that the largest concentrations are confined to the boundary layer and decrease with height. There is some sign of transport of $\mathrm{HCHO}$ into the upper troposphere by deep convection in the tropics. In DJF the zonal mean maximum is found around $10^{\circ} \mathrm{N}$, pointing to high $\mathrm{HCHO}$ values in Africa north of the equator. In JJA the highest values are seen around $40^{\circ} \mathrm{N}$ (North American signal) and around $10^{\circ} \mathrm{S}$ (combination of South America, Africa and Indonesia).

\section{Conclusions}

A data assimilation system for global reactive gases, aerosols and greenhouse gases was developed and consolidated as part of the EU funded GEMS and MACC projects. This system was used in the MACC project to produce an $8 \mathrm{yr}$ long reanalysis of atmospheric composition data for the period 2003-2010, by assimilating satellite data to constrain $\mathrm{O}_{3}, \mathrm{CO}, \mathrm{NO}_{2}, \mathrm{CO}_{2}, \mathrm{CH}_{4}$, and aerosol optical depth. The reanalysis data are constrained in a consistent way by observations and the model simulation. This paper describes the 

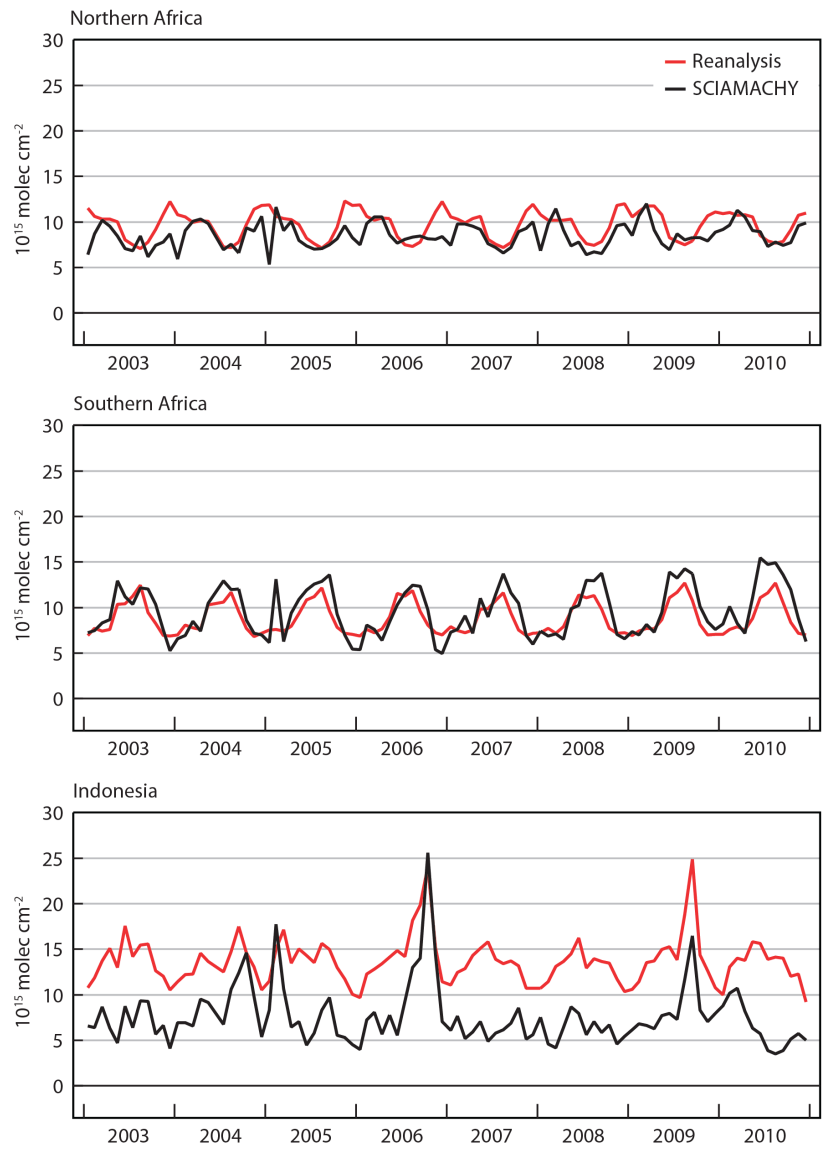

Fig. 32. Time series of monthly mean area-averaged tropospheric $\mathrm{HCHO}$ columns in $10^{15}$ molecules $\mathrm{cm}^{-2}$ from the MACC reanalysis (red), and IUP-SCIAMACHY (black) for northern Africa (top), southern Africa (middle) and Indonesia (bottom). Only land points were used in these calculations.

assimilation system for the reactive gases used in the MACC reanalysis and presents some validation results of the reanalysis fields for $\mathrm{CO}, \mathrm{O}_{3}, \mathrm{NO}_{2}$ and $\mathrm{HCHO}$. Total column values are generally in very good agreement with independent observations, but profiles can show some problems in the boundary layer where concentrations are dominated by emissions. There are some discontinuities in the data set related to instrument changes and issues with the bias correction of ozone data. These discontinuities limit the usability of the reanalysis as a research tool for assessing the state of the climate or for studying interannual variability. The most important issues are summarized in Appendix A. A future reanalysis of atmospheric composition would benefit from using an improved CTM, or chemistry routines integrated in the IFS, better emissions, improved bias correction (e.g. to ensure that bias correction is anchored properly and does not drift; more sophisticated bias correction for $\mathrm{CO}$ ), and the exploration of more data sets, especially profile data if available.

Assimilating MOPITT and IASI CO retrievals in the MACC reanalysis leads to an improved CO field compared to a MOZART-3 stand-alone run carried out with the MACC configuration. The reanalysis $\mathrm{CO}$ field has a realistic seasonal cycle and interhemispheric differences. Total column values in 2008 to 2010 are low compared to the satellite retrievals at high northern latitudes, but in other areas the agreement with MOPITT and IASI is good. Using MACCity emissions to provide boundary conditions for the MOZART-3 CTM leads to tropospheric $\mathrm{CO}$ values that are $10-20 \%$ too low compared to MOZAIC data through most of the troposphere. In the boundary layer at urban sites affected by air pollution, the negative biases are larger, suggesting an underestimation of $\mathrm{CO}$ or precursor emissions. Surface $\mathrm{CO}$ from the MACC reanalysis agrees well with NOAA/GMD observations, which indicates that, despite uncertainties of satellite measurements in the lower troposphere, assimilation of $\mathrm{CO}$ data from such products can lead to a good representation of surface $\mathrm{CO}$ concentrations for unpolluted regions.

Comparison with independent data has shown ozone from the MACC reanalysis to be considerably better than a freerunning MOZART-3 CTM. Stratospheric ozone fields from the MACC reanalysis agree with ozonesondes and ACE-FTS data to within $\pm 10 \%$ in most situations. In the troposphere the reanalysis shows biases of $-5 \%$ to $+10 \%$ with respect to ozonesondes and MOZAIC aircraft observations in the extratropics, but has larger negative biases in the tropics (up to $-40 \%$ around $100 \mathrm{hPa}$ ). These biases are partly due to biases in the underlying MOZART-3 CTM, but a time varying bias in the troposphere is the result of using a variational bias correction scheme without MLS as an anchor before 2008 (see also Sect. 2.3.2). Area averaged total column ozone agrees with data from KNMI's multi-sensor reanalysis product to within a few percent. Surface ozone from the reanalysis agrees with EMEP surface observations over Europe to within $\pm(5-10)$ ppbv. However, there are some diurnal variations in the surface ozone biases that need to be investigated further. The biases of the MACC reanalysis with respect to ozonesondes are smaller than biases of ERA-Interim ozone fields.

Assimilating $\mathrm{NO}_{2}$ retrievals from SCIAMACHY in the MACC reanalysis has only little impact, and the $\mathrm{NO}_{2}$ fields from the reanalysis and the control run are very similar. A possible reason for this is the short lifetime of $\mathrm{NO}_{2}$, so that the impact the data have in the analysis is lost again quickly. $\mathrm{NO}_{2}$ fields from the reanalysis show the right seasonality over polluted urban areas of the $\mathrm{NH}$ and over tropical biomass burning areas, but underestimate wintertime $\mathrm{NO}_{2}$ maxima over anthropogenic regions and overestimate $\mathrm{NO}_{2}$ in northern and southern Africa during the tropical biomass burning seasons.

Tropospheric HCHO is quite well simulated in the MACC reanalysis even though no satellite data are assimilated. It agrees well with independent IUP-SCIAMACHY observations over regions dominated by biogenic emissions with some anthropogenic input, such as the eastern US and China, and also over African regions influenced by biogenic sources 

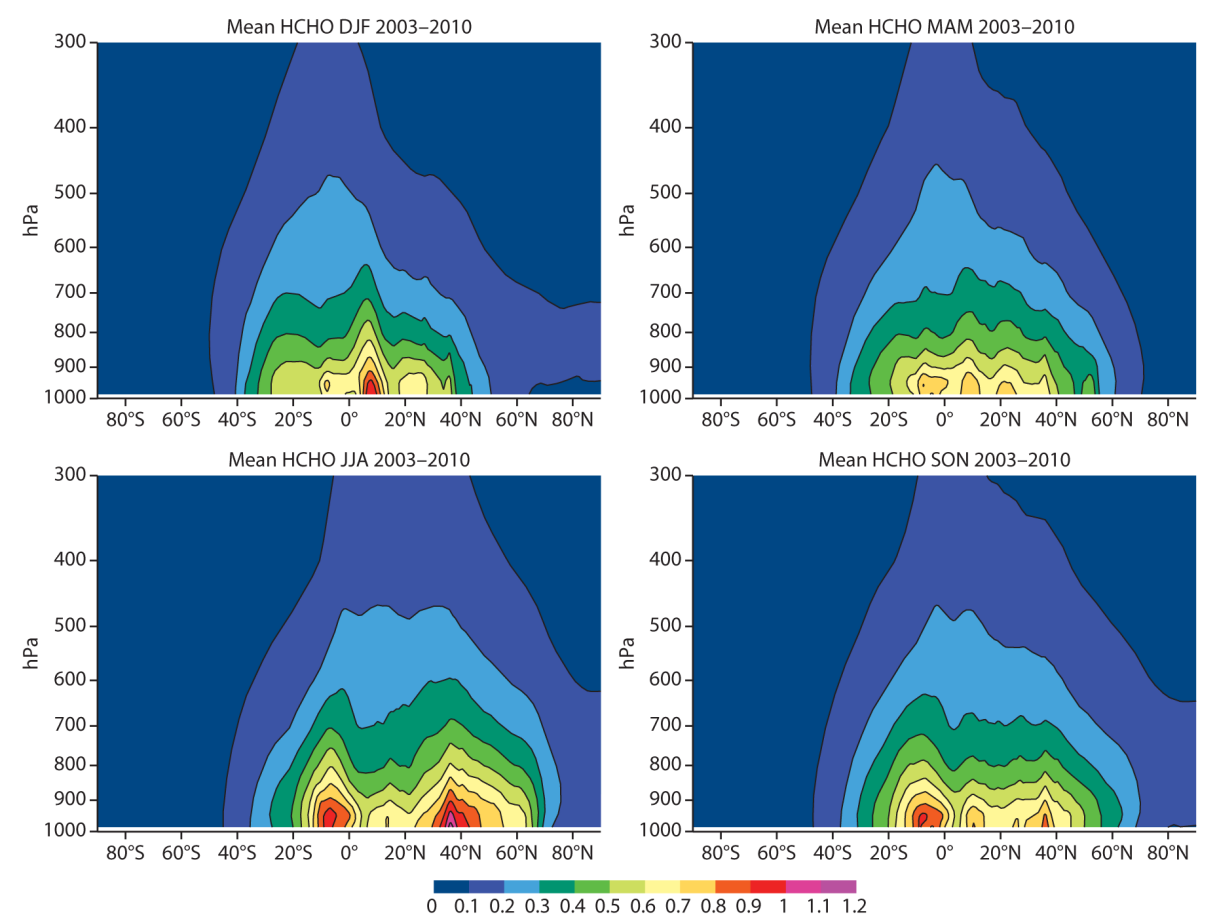

Fig. 33. Seasonal mean zonal average HCHO cross sections from the MACC reanalysis in ppbv for DJF (top left), MAM (top right), JJA (bottom left) and SON (bottom right), averaged over the years 2003 to 2010. Red indicates higher values of the field, blue lower values.

and biomass burning. Over Indonesia, however, the reanalysis has a large positive bias that is not seen in the control run, but the high $\mathrm{HCHO}$ values observed during the Indonesian fires of 2006 are very well captured by the reanalysis.

The MACC reanalysis is a valuable $8 \mathrm{yr}$ long atmospheric composition data set that can, for example, be used as boundary conditions for regional models, climatological studies or for model evaluation. In addition to the four GRG IFS fields analyzed in this paper, more chemical species are available from the MOZART-3 CTM output. The MACC model and assimilation system is also run in NRT to produce daily analyses and 5-day forecasts of reactive gases and aerosols. Data from the MACC reanalysis and the NRT analysis are available from the MACC data server http:// www.gmes-atmosphere.eu. Further validation results from the MACC reanalysis can be found on the MACC verification web page http://www.gmes-atmosphere.eu/services/gac/ global_verification/.

Since November 2011, the MACC-II project has begun as a successor to MACC. This project will continue to deliver the daily analyses and forecasts of atmospheric composition. There are no plans for a new reanalysis in MACC-II, but the MACC reanalysis will be extended to more recent years, and selected periods will be rerun to test changes to the assimilation system and new input data sets.

\section{Appendix A}

\section{Summary of known issues with the reactive gas fields}

There are some issues with the reactive gas analysis fields that a user should be aware of because they cause discontinuities in the data set:

- The biomass burning emissions were changed on 1 January 2009 from a preliminary version of GFED3 to GFAS version 1.0. The GFAS version 1.0 emissions budget is about $18 \%$ higher than those used during the first 6 yr.

- Using MACCity emissions to provide lower boundary conditions for the MOZART-3 CTM led to too-low CO analysis values, especially in the boundary layer.

- After 23 March 2010 NRT MOPITT CO data were used in the reanalysis instead of the offline product. This change did not have a noticeable impact on the reanalysis fields.

- Assimilation of IASI CO after 1 April 2008 led to some changes in the $\mathrm{CO}$ field.

- Using variational bias correction for MLS ozone profiles led to increased tropospheric ozone and changes to ozone above $15 \mathrm{hPa}$. However, it did not affect the total column ozone field. These drifts stopped on 1 January 2008 when the bias correction was switched off 
for MLS, and afterwards agreement with independent ozonesondes and MOZAIC data was improved.

- Using NRT MLS data instead of the offline product after 16 March 2009 resulted in larger departures in the upper troposphere and lower stratosphere, because the lowest 3 layers $(68-100,100-146$, and $146-215 \mathrm{hPa})$ of the MLS data could not be used.

- NRT OMI ozone columns were assimilated instead of the offline product between 21 March 2007 and 31 December 2007. This did not have a noticeable impact on the ozone analysis.

- A model upgrade to MOZART 3.5 was implemented on 1 January 2009, which slightly improved the representation of the ozone hole in the control run but did not affect the other model fields.

- $\mathrm{NO}_{2}$ SCIAMACHY retrievals V1.04 were assimilated until 30 June 2007, SCIAMACHY V1.1 data were assimilated after 11 September 2007, but this only has a minor impact on the analysis fields.

Acknowledgements. MACC was funded by the European Commission under the EU Seventh Research Framework Programme, contract number 218793. The CO products from IASI are available from the Ether French atmospheric database (http://ether.ipsl.jussieu.fr). We thank Doug Kinnison at NCAR, Boulder, for support with the MOZART model. We acknowledge the free use of tropospheric $\mathrm{NO}_{2}$ column data from the SCIAMACHY sensor from www.temis.nl. MOPITT data are from NASA. Mihalis Vrekoussis acknowledges European Union research fellowship (FP7-PEOPLE-2009-RG Grant, PERG-GA2009-256391).

Edited by: W. Lahoz

\section{References}

Abbot, D. S., Palmer, P. I., Martin, R. V., Chance, K. V., Jacob, D. J., and Guenther, A.: Seasonal and interannual variability of North American isoprene emissions as determined by formaldehyde column measurements from space, Geophys. Res. Lett., 30, 1886, doi:10.1029/2003GL017336, 2003.

Andersson, E. and Järvinen, H.: Variational quality control, Q. J. Roy. Meteor. Soc., 125, 697-722, 1999.

Andreae, M. O. and Merlet, P.: Emission of trace gases and aerosols from biomass burning. Global Biogeochem. Cy., 15, 955-966, 2001

Arellano Jr., A. F., Raeder, K., Anderson, J. L., Hess, P. G., Emmons, L. K., Edwards, D. P., Pfister, G. G., Campos, T. L., and Sachse, G. W.: Evaluating model performance of an ensemblebased chemical data assimilation system during INTEX-B field mission, Atmos. Chem. Phys., 7, 5695-5710, doi:10.5194/acp-75695-2007, 2007.
Atkinson, R.: Gas-phase tropospheric chemistry of organic compounds, J. Phys. Chem. Ref. Data Monogr., 2, 13-46, 1994.

Auligné, T., McNally, A. P., and Dee, D. P.: Adaptive bias correction for satellite data in a numerical weather prediction system, Q. J. Roy. Meteor. Soc., 133, 631-642, 2007.

Baklanov, A., Korsholm, U., Mahura, A., Petersen, C., and Gross, A.: ENVIRO-HIRLAM: on-line coupled modelling of urban meteorology and air pollution, Adv. Sci. Res., 2, 41-46, 2008.

Barkley, M.: Description of MEGAN biogenic VOC emissions in GEOS-Chem, available at: http://acmg.seas.harvard.edu/ geos/wiki_docs/emissions/megan.pdf (last access: 29 November 2012), 2010.

Benedetti, A., Morcrette, J.-J., Boucher, O., Dethof, A., Engelen, R. J., Fisher, M., Flentje, H., Huneeus, N., Jones, L., Kaiser, J. W., Kinne, S., Mangold, A., Razinger, M., Simmons, A. J., Suttie, M., and the GEMS-AER team: Aerosol analysis and forecast in the European Centre for Medium-Range Weather Forecasts Integrated Forecast System: 2. Data assimilation, J. Geophys. Res., 114, D13205, doi:10.1029/2008JD011115, 2009.

Bhartia, P. K. and Wellemeyer, C.: TOMS-V8 total $\mathrm{O}_{3}$ algorithm, in: OMI Ozone Product ATBD Volume II, NASA Goddard Space Flight Center, Greenbelt, MD, USA, 2002.

Bhartia, P. K., McPeters, R. D., Mateer, C. L., Flynn, L. E., and Wellemeyer, C., Algorithm for the estimation of vertical ozone profiles from the backscattered ultraviolet technique, J. Geophys. Res., 101, 18793-18806, 1996.

Boersma, K. F., Eskes, H. J., and Brinksma, E. J.: Error analysis for tropospheric $\mathrm{NO}_{2}$ retrieval from space, J. Geophys. Res., 109, D04311, doi:10.1029/2003JD003962, 2004.

Brewer, A. W.: Evidence for a world circulation provided my measurements of helium and water vapour distribution in the stratosphere, Q. J. Roy. Meteor. Soc., 75, 351-363, 1949.

Cariolle, D. and Teyssèdre, H.: A revised linear ozone photochemistry parameterization for use in transport and general circulation models: multi-annual simulations, Atmos. Chem. Phys., 7, 2183 2196, doi:10.5194/acp-7-2183-2007, 2007.

Carli, B., Alpaslan, D., Carlotti, M., Castelli, E., Ceccherini, S., Dinelli, B. M., Dudhia, A., Flaud, J. M., Höpfner, M., Jay, V., Magnani, L., Oelhaf, H., Payne, V., Piccolo, C., Prosperi, M., Raspollini, P., Ridolfi, M., Remedios, J., and Spang, R.: First results from MIPAS/ENVISAT with operational level 2 code, Adv. Space Res., 33, 1012-1019, doi:10.1016/S0273-1177(03)005842, 2004.

Chapman, S.: On ozone and atomic oxygen in the upper atmosphere, Philos. Mag., 10, 369-383, 1930.

Christian, T. J., Kleiss, B., Yokelson, R. J., Holzinger, R., Crutzen, P. J., Hao, W. M., Saharjo, B. H., and Ward, D. E.: Comprehensive laboratory measurements of biomass- burning emissions: 1. emissions from indonesian, african, and other fuels, J. Geophys. Res., 108, doi:10.1029/2003JD003704, 2003.

Clerbaux, C., Boynard, A., Clarisse, L., George, M., HadjiLazaro, J., Herbin, H., Hurtmans, D., Pommier, M., Razavi, A., Turquety, S., Wespes, C., and Coheur, P.-F.: Monitoring of atmospheric composition using the thermal infrared IASI/MetOp sounder, Atmos. Chem. Phys., 9, 6041-6054, doi:10.5194/acp9-6041-2009, 2009. 
Courtier, P., Thépaut, J.-N. and Hollingsworth, A.: A strategy for operational implementation of 4D-Var, using an incremental approach, Q. J. Roy. Meteor. Soc., 120, 1367-1388, 1994.

Dee, D. P.: Variational bias correction of radiance data in the ECMWF system, in: Proceedings of the ECMWF workshop on assimilation of high spectral resolution sounders in NWP, Reading, UK, 28 June-1 July 2004, 97-112, 2004.

Dee, D. P. and Uppala, S.: Variational bias correction of satellite radiance data in the ERA-Interim reanalysis, Q. J. Roy. Meteor. Soc., 135, 1830-1841, 2009.

Dee, D. P., Uppala, S. M., Simmons, A. J., Berrisford, P., Poli, P., Kobayashi, S., Andrae, U., Balmaseda, M. A., Balsamo, G., Bauer, P., Bechtold, P., Beljaars, A. C. M., van de Berg, L., Bidlot, J., Bormann, N., Delsol, C., Dragani, R., Fuentes, M., Geer, A. J., Haimberger, L., Healy, S. B., Hersbach, H., Hólm, E. V., Isaksen, L., Kållberg, P., Köhler, M., Matricardi, M., McNally, A. P., Monge-Sanz, B. M., Morcrette, J.-J., Park, B.-K., Peubey, C., de Rosnay, P., Tavolato, C., Thépaut, J.-N., and Vitarta, F.: The ERA-Interim reanalysis: configuration and performance of the data assimilation system, Q. J. Roy. Meteor. Soc., 137, 553-597, 2011.

Deeter, M. N., Emmons, L. K., Francis, G. L., Edwards, D. P., Gille, G. C., Warner, J. X., Khattatov, B., Ziskin, D., Lamarque, J.-F., Ho, S.-P., Yudin, V., Attié, J.-L., Packman, D., Chen, J., Mao, D., and Drummond, J. R.: Operational carbon monoxide retrieval algorithm and selected results for the MOPITT instrument, J. Geophys. Res., 108, 4399, doi:10.1029/2002JD003186, 2003.

Deeter, M. N., Edwards, D. P., Gille, J. C., and Drummond, J. R.: CO retrievals based on MOPITT near-infrared observations, J. Geophys. Res., 114, D04303, doi:10.1029/2008JD010872, 2009.

Deeter, M. N., Edwards, D. P., Gille, G. C., Emmons, L. K., Francis, G., Ho, S.-P., Mao, D., Masters, D., Worden, H., Drummond, J. R., and Novelli, P. C.: The MOPITT version 4 CO product: algorithm enhancements, validation, and long-term stability, J. Geophys. Res., 115, D07306, doi:10.1029/2009JD013005, 2010.

Dethof, A.: Assimilation of ozone retrievals from the MIPAS instrument on board ENVISAT, ECMWF Technical Memorandum 428, available at: http://www.ecmwf.int/publications/library/do/ references/list/14 (last access: 29 November 2012), 2003.

Dethof, A. and Hólm, E. V.: Ozone assimilation in the ERA-40 reanalysis project, Q. J. Roy. Meteor. Soc., 130, 2851-2872, 2004.

De Smedt, I., Müller, J.-F., Stavrakou, T., van der A, R., Eskes, H., and Van Roozendael, M.: Twelve years of global observations of formaldehyde in the troposphere using GOME and SCIAMACHY sensors, Atmos. Chem. Phys., 8, 4947-4963, doi:10.5194/acp-8-4947-2008, 2008.

Dobson, G. M.: Origin and distribution of the polyatomic molecules in the atmosphere, Proc. Roy. Soc. Lond. A, 236, 187-193, 1956.

Dragani, R.: On the quality of the ERA-Interim ozone reanalyses: comparisons with in situ data, ERA Report Series, 2, avaiable at: http://www.ecmwf.int/publications/library/do/references/list/ 782009 (last access: 29 November 2012), 2010.

Dragani, R.: On the quality of the ERA-Interim ozone reanalyses: comparisons with satellite data, Q. J. Roy. Meteor. Soc., 137, 1312-1326, doi:http://dx.doi.org/10.1002/qj.82110.1002/qj.821, 2011.

Dupuy, E., Walker, K. A., Kar, J., Boone, C. D., McElroy, C. T., Bernath, P. F., Drummond, J. R., Skelton, R., McLeod, S. D., Hughes, R. C., Nowlan, C. R., Dufour, D. G., Zou, J., Nichi- tiu, F., Strong, K., Baron, P., Bevilacqua, R. M., Blumenstock, T., Bodeker, G. E., Borsdorff, T., Bourassa, A. E., Bovensmann, H., Boyd, I. S., Bracher, A., Brogniez, C., Burrows, J. P., Catoire, V., Ceccherini, S., Chabrillat, S., Christensen, T., Coffey, M. T., Cortesi, U., Davies, J., De Clercq, C., Degenstein, D. A., De Mazière, M., Demoulin, P., Dodion, J., Firanski, B., Fischer, H., Forbes, G., Froidevaux, L., Fussen, D., Gerard, P., Godin-Beekmann, S., Goutail, F., Granville, J., Griffith, D., Haley, C. S., Hannigan, J. W., Höpfner, M., Jin, J. J., Jones, A., Jones, N. B., Jucks, K., Kagawa, A., Kasai, Y., Kerzenmacher, T. E., Kleinböhl, A., Klekociuk, A. R., Kramer, I., Küllmann, H., Kuttippurath, J., Kyrölä, E., Lambert, J.-C., Livesey, N. J., Llewellyn, E. J., Lloyd, N. D., Mahieu, E., Manney, G. L., Marshall, B. T., McConnell, J. C., McCormick, M. P., McDermid, I. S., McHugh, M., McLinden, C. A., Mellqvist, J., Mizutani, K., Murayama, Y., Murtagh, D. P., Oelhaf, H., Parrish, A., Petelina, S. V., Piccolo, C., Pommereau, J.-P., Randall, C. E., Robert, C., Roth, C., Schneider, M., Senten, C., Steck, T., Strandberg, A., Strawbridge, K. B., Sussmann, R., Swart, D. P. J., Tarasick, D. W., Taylor, J. R., Tétard, C., Thomason, L. W., Thompson, A. M., Tully, M. B., Urban, J., Vanhellemont, F., Vigouroux, C., von Clarmann, T., von der Gathen, P., von Savigny, C., Waters, J. W., Witte, J. C., Wolff, M., and Zawodny, J. M.: Validation of ozone measurements from the Atmospheric Chemistry Experiment (ACE), Atmos. Chem. Phys., 9, 287-343, doi:10.5194/acp-9-287-2009, 2009.

Edwards, D. P., Emmons, L. K., Hauglustaine, D. A., Chu, A., Gille, J. C., Kaufman, Y. J., Pétron, G., Yurganov, L. N., Giglio, L., Deeter, M. N., Yudin, V., Ziskin, D. C., Warner, J., Lamarque, J.-F., Francis, G. L., Ho, S. P., Mao, D., Chan, J., and Drummond, J. R.: Observations of carbon monoxide and aerosol from the Terra satellite: Northern Hemisphere variability, J. Geophys. Res., 109, D24202, doi:10.1029/2004JD004727, 2004.

Elbern, H., Schwinger, J., and Botchorishvili, R.: Chemical state estimation for the middle atmosphere by four-dimensional variational data assimilation: system configuration, J. Geophys. Res., 115, D06302, doi:10.1029/2009JD011953, 2010.

Elguindi, N., Clark, H., Ordóñez, C., Thouret, V., Flemming, J., Stein, O., Huijnen, V., Moinat, P., Inness, A., Peuch, V.H., Stohl, A., Turquety, S., Athier, G., Cammas, J.-P., and Schultz, M.: Current status of the ability of the GEMS/MACC models to reproduce the tropospheric $\mathrm{CO}$ vertical distribution as measured by MOZAIC, Geosci. Model Dev., 3, 501-518, doi:10.5194/gmd-3-501-2010, 2010.

Emmons, L. K., Deeter, M. N., Gille, G. C., Edwards, D. P., Attié, J.-L., Warner, J., Ziskin, D., Francis, G., Khattatov, B., Yudin, V., Lamarque, J.-F., Ho, S.-P., Mao, D., Chen, J. S., Drummond, J., Novelli, P., Sachse, G., Coffey, M. T., Hannigan, J. W., Gerbig, C., Kawakami, S., Kondo, Y., Takegawa, N., Schlager, H., Baehr, J., and Ziereis, H.: Validation of Measurements of Pollution in the Troposphere (MOPITT) CO retrievals with aircraft in situ profiles, J. Geophys. Res., 109, D03309, doi:10.1029/2003JD004101, 2004.

Emmons, L. K., Pfister, G. G., Edwards, D. P., Gille, J. C., Sachse, G., Blake, D., Wofsy, S., Gerbig, C., Matross, D., and Nédélec, P.: Measurements of Pollution in the Troposphere (MOPITT) validation exercises during summer 2004 field campaigns over North America, J. Geophys. Res., 112, D12S02, doi:10.1029/2006JD007833, 2007. 
Engelen, R. J., Serrar, S., and Chevallier, F.: Four-dimensional data assimilation of atmospheric $\mathrm{CO}_{2}$ using AIRS observations, J. Geophys. Res., 114, D03303, doi:10.1029/2008JD010739, 2009.

Errera, Q., Daerden, F., Chabrillat, S., Lambert, J. C., Lahoz, W. A., Viscardy, S., Bonjean, S., and Fonteyn, D.: 4D-Var assimilation of MIPAS chemical observations: ozone and nitrogen dioxide analyses, Atmos. Chem. Phys., 8, 6169-6187, doi:10.5194/acp8-6169-2008, 2008.

Eskes, H. J. and Boersma, K. F.: Averaging kernels for DOAS totalcolumn satellite retrievals, Atmos. Chem. Phys., 3, 1285-1291, doi:10.5194/acp-3-1285-2003, 2003.

Eskes, H. J., van Velthoven, P. F. J., and Kelder, H. M.: Global ozone forecasting based on ERS-2 GOME observations, Atmos. Chem. Phys., 2, 271-278, doi:10.5194/acp-2-271-2002, 2002.

Eskes, H., van Velthoven, P., Valks, P., and Kelder, H. H.: Assimilation of GOME total ozone satellite observations in a threedimensional tracer transport model, Q. J. Roy. Meteor. Soc., 129, 1663-1681, 2003.

Eskes, H. J., van der A, R. J., Brinksma, E. J., Veefkind, J. P., de Haan, J. F., and Valks, P. J. M.: Retrieval and validation of ozone columns derived from measurements of SCIAMACHY on Envisat, Atmos. Chem. Phys. Discuss., 5, 44294475, doi:10.5194/acpd-5-4429-2005, 2005.

Eyring, V., Isaksen I. S. A., Berntsen, T., Collins, W. J., Corbett, J. J., Endresen, O., Grainger, R. G., Moldanova, J., Schlager, H., and Stevenson, D. S.: Transport impacts on atmosphere and climate: Shipping, Atmos. Environ., 44, 4735-4771, doi:10.1016/j.atmosenv.2009.04.059, 2010.

Fisher, M.: Generalized frames on the sphere with application to background error covariance modelling, in: Proceedings of the Seminar on resent developments in numerical methods for atmospheric and ocean modelling, 6-10 September 2004, ECMWF, 87-101, available from ECMWF, Shinfield Park, Reading, Berkshire, RG2 9AX, UK, 2004.

Fisher, M.: Wavelet Jb - a new way to model the statistics of background errors, ECMWF Newsletter, 106, 23-28, available from ECMWF, Shinfield Park, Reading, Berkshire, RG29AX, UK, 2006.

Fisher, M. and Andersson, E.: Developments in 4D-Var and Kalman Filtering, ECMWF Technical Memorandum 347, available from ECMWF, Shinfield Park, Reading, Berkshire, RG29AX, UK, 2001.

Flemming, J., Inness, A., Flentje, H., Huijnen, V., Moinat, P., Schultz, M. G., and Stein, O.: Coupling global chemistry transport models to ECMWF's integrated forecast system, Geosci. Model Dev., 2, 253-265, doi:10.5194/gmd-2-253-2009, 2009.

Flemming, J., Dethof, A., Moinat, P., Ordóñez, C., Peuch, V.-H., Segers, A., Schultz, M., Stein, O., van Weele, M.: Coupling global atmospheric chemistry transport models to ECMWF Integrated Forecasts System for forecast and data assimilation within GEMS, in: Integrated Systems of Meso-Meteorological and Chemical Transport Models, edited by: Baklanov, A., Mahura, A., and Sokhi, R., Springer-Verlag, Berlin Heidelberg, doi:10.1007/978-3-642-13980-2_10, 2011a.

Flemming, J., Inness, A., Jones, L., Eskes, H. J., Huijnen, V., Schultz, M. G., Stein, O., Cariolle, D., Kinnison, D., and Brasseur, G.: Forecasts and assimilation experiments of the Antarctic ozone hole 2008, Atmos. Chem. Phys., 11, 1961-1977, doi:10.5194/acp-11-1961-2011, $2011 \mathrm{~b}$.
Foret, G., Hamaoui, L., Schmechtig, C., Eremenko, M., Keim, C., Dufour, G., Boynard, A., Coman, A., Ung, A., and Beekmann, M.: Evaluating the potential of IASI ozone observations to constrain simulated surface ozone concentrations, Atmos. Chem. Phys., 9, 8479-8491, doi:10.5194/acp-9-8479-2009, 2009.

Fortems-Cheiney, A., Chevallier, F., Pison, I., Bousquet, P., Szopa, S., Deeter, M. N., and Clerbaux, C.: Ten years of $\mathrm{CO}$ emissions as seen from Measurements of Pollution in the Troposphere (MOPITT), J. Geophys. Res., 116, D05304, doi:10.1029/2010JD014416, 2011.

Geer, A. J., Peubey, C., Bannister, R. N., Brugge, R., Jackson, D. R., Lahoz, W. A., Migliorini, S., O’Neill, A., and Swinbank, R.: Assimilation of stratospheric ozone from MIPAS into a global general-circulation model: the September 2002 vortex split, Q. J. Roy. Meteor. Soc., 132, 231-257, doi:10.1256/qj.04.181, 2006.

George, M., Clerbaux, C., Hurtmans, D., Turquety, S., Coheur, P.F., Pommier, M., Hadji-Lazaro, J., Edwards, D. P., Worden, H., Luo, M., Rinsland, C., and McMillan, W.: Carbon monoxide distributions from the IASI/METOP mission: evaluation with other space-borne remote sensors, Atmos. Chem. Phys., 9, 8317-8330, doi:10.5194/acp-9-8317-2009, 2009.

Gibson, J. K., Kållberg, P., Uppala, S., Nomura, A., Hernandez, A., and Serrano, E.: ERA Description, ERA-15 Project Report Series 1, ECMWF, available at: http://www.ecmwf.int/publications/ library/do/references/list/191 (last access: 29 November 2012), 1997.

Granier, C., Bessagnet, B., Bond, T., D’Angiola, A., Denier van der Gon, H., Frost, G. J., Heil, A., Kaiser, J. W., Kinne, S., Klimont, Z., Kloster, S., Lamarque, J.-F., Liousse, C., Masui, T., Meleux, F., Mieville, A., Ohara, R., Raut, J.-C., Riahi, K., Schultz, M. G., Smith, S. G., Thompson, A., van Aardenne, J., van der Werf, G. R., and van Vuuren, D. P.: Evolution of anthropogenic and biomass burning emissions of air pollutants at global and regional scales during the 1980-2010 period, Clim. Change, 109, 163-190, doi:10.1007/s10584-011-0154-1, 2011a.

Granier, C., D’Angiola, A., Raut, J.-C., Bessagnet, B., Meleux, F., van der Gon, H. D., Kinne, S., Kaiser, J. W., Heil, A., and Schultz, M. G., van der Werf, G. R., Liousse, C., Darras, S., Pinot, V., and Mievillea, A.: Updated inventory of global and European regional emissions based on the RETRO system: evaluation of the anthropogenic emissions used in the MACC project, MACC deliverable available from MACC website, http://www.gmes-atmosphere.eu/ documents/deliverables/d-emis/MACC_D_D-EMIS-1.4.pdf (last access: 29 November 2012), 2011 b.

Granier, C., Lamarque, J. F., Mieville, A., Muller, J. F., Olivier, J., Orlando, J., Peters, J., Petron, G., Tyndall, G., and Wallens, S.: POET, a database of surface emissions of ozone precursors, available at: http://www.aero.jussieu.fr/projet/ACCENT/POET. php, 2005.

Griffin, R. J., Chen, J., Carmody, K., and Vutukuru, S.: Contribution of gas phase oxidation of volatile organic compounds to atmospheric carbon monoxide levels in two areas of the united States, J. Geophys. Res., 11, D10S17, doi:10.1029/2006JD007602, 2007.

Guenther, A., Karl, T., Harley, P., Wiedinmyer, C., Palmer, P. I., and Geron, C.: Estimates of global terrestrial isoprene emissions using MEGAN (Model of Emissions of Gases and Aerosols from Nature), Atmos. Chem. Phys., 6, 3181-3210, doi:10.5194/acp-6- 
3181-2006, 2006.

Hansen, J., Sato, M., and Ruedy, R.: Radiative forcing and climate response, J. Geophys. Res., 102, 6831-6864, 1997.

Henze, D. K., Hakami, A., and Seinfeld, J. H.: Development of the adjoint of GEOS-Chem, Atmos. Chem. Phys., 7, 2413-2433, doi:10.5194/acp-7-2413-2007, 2007.

Hollingsworth, A., Engelen, R. J., Textor, C., Benedetti, A., Boucher, O., Chevallier, F., Dethof, A., Elbern, H., Eskes, H., Flemming, J., Granier, C., Kaiser, J. W., Morcrette, J.-J., Rayner, R., Peuch, V.-H., Rouil, L., Schultz, M. G., Simmons, A. J., and The GEMS Consortium: Toward a monitoring and forecasting system for atmospheric composition: the GEMS project, B. Am. Meteorol. Soc., 89, 1147-1164, doi:10.1175/2008BAMS2355.1, 2008.

Holloway, J. S., Jakoubek, R. O., Parrish, D. D., Gerbig, C., VolzThomas, A., Schmitgen, S., Fried, A., Wert, B., Henry, B., and Drummond, J. R.: Airborne intercomparison of vacuum ultraviolet fluorescence and tunable diode laser absorption measurements of tropospheric carbon monoxide, J. Geophys. Res., 105, 24251-24261, doi:10.1029/2000JD900237, 2000.

Hólm, E. V., Untch, A., Simmons, A., Saunders, R., Bouttier, F., and Andersson, E.: Multivariate ozone assimilation in fourdimensional data assimilation, in: Proceedings of the Soda Workshop on Chemical Data Assimilation, 9-10 December 1998, KNMI, De Bilt, The Netherlands, 89-94, 1999.

Hortal, M. and Simmons, A. J.: Use of reduced Gaussian grids in spectral models, Mon. Weather Rev., 119, 1057-1074, 1991.

Hudman, R. C., Murray, L. T., Jacob, D. J., Millet, D. B., Turquety, S., Wu, S., Blake, D. R., Goldstein, A. H., Holloway, J., Sachse, G. W.: Biogenic versus anthropogenic sources of CO over the United States, Geophys. Res. Lett., 35, L04801, doi:10.1029/2007GL032393, 2008.

Huijnen, V., Flemming, J., Kaiser, J. W., Inness, A., Leitão, J., Heil, A., Eskes, H. J., Schultz, M. G., Benedetti, A., HadjiLazaro, J., Dufour, G., and Eremenko, M.: Hindcast experiments of tropospheric composition during the summer 2010 fires over western Russia, Atmos. Chem. Phys., 12, 4341-4364, doi:10.5194/acp-12-4341-2012, 2012.

Inness, A., Flemming, J., Suttie, M. and Jones, L.: GEMS data assimilation system for chemically reactive gases, ECMWF RD Tech Memo 587, available at: http://www. ecmwf.int/publications/library/do/references/list/14 (last access: 29 November 2012), 2009.

Isaksen, I. S. A., Granier, C., Myhre, G., Berntsen, T. K., Dalsøren, S. B., Gauss, M., Klimont, Z., Benestad, R., Bousquet, P., Collins, W., Cox, T., Eyring, V., Fowler, D., Fuzzi, S., Jöckel, P., Laj, P., Lohmann, U., Maione, M., Monks, P., Prevot, A. S. H., Raes, F., Richter, A., Rognerud, B., Schulz, M., Shindell, D., Stevenson, D. S., Storelvmo, T., Wang, W.-C., van Weele, M., Wild, M., and Wuebbles, D.: Atmospheric composition change: climate-chemistry interactions. Atmos. Environ., 43, 5138-5192, doi:10.1016/j.atmosenv.2009.08.003, 2009.

Jonquières, I., Marenco, A., Maalej, A., and Rohrer, F.: Study of ozone formation and transatlantic transport from biomass burning emissions over West Africa during the airborne Tropospheric Ozone Campaigns TROPOZ I and TROPOZ II, J. Geophys. Res., 103, 19059-19073, doi:10.1029/98JD00819, 1998.

Justice, C. O., Giglio, L., Korontzi, S., Owens, J., Morrisette, J. T., Roy, D., Descloitres, J., Alleaume, S., Petitcolin, F., and Kauf- man, Y.: The MODIS fire products, Remote Sens. Environ., 83, 244-262, 2002.

Kaiser, J. W., Heil, A., Schultz, M. G., Stein, O., van der Werf, G. R., Wooster, M. J., and Xu, W.: Final report on implementation and quality of the D-FIRE assimilation system, MACC deliverable D D-FIRE 7, ECMWF, http://www.gmes-atmosphere.eu/ documents/deliverables/d-fire/D-FIRE_final_report_v7.pdf (last access: 29 November 2012), 2011.

Kaiser, J. W., Heil, A., Andreae, M. O., Benedetti, A., Chubarova, N., Jones, L., Morcrette, J.-J., Razinger, M., Schultz, M. G., Suttie, M., and van der Werf, G. R.: Biomass burning emissions estimated with a global fire assimilation system based on observed fire radiative power, Biogeosciences, 9 , 527-554, doi:10.5194/bg-9-527-2012, 2012.

Kalnay, E., Kanamitsu, M., Kistler, R., Collins, W., Deaven, D., Gandin, L., Iredell, M., Saha, S., White, G., Woollen, J., Zhu, Y., Leetmaa, A., Reynolds, R., Chelliah, M., Ebisuzaki, W., Higgins, W., Janowiak, J., Mo, K. C., Ropelewski, C., Wang, J., Jenne, R., and Joseph, D.: The NCEP/NCAR 40-year reanalysis project, B. Am. Meteorol. Soc., 77, 437-470, 1996.

Kanakidou, M. and Crutzen, P. J.: The photochemical source of carbon monoxide: importance, uncertainties, and feedbacks, Chemosphere Global Change Sci., 1, 91-109, 1999.

Kar, J., Bremer, H., Drummond, J. R., Rochon, Y. J., Jones, D. B. A., Nichitiu, F., Zou, J., Liu, J., Gille, J. C., Edwards, D. P., Deeter, M. N., Francis, G., Ziskin, D., and Warner, J.: Evidence of vertical transport of carbon monoxide from Measurements of Pollution in the Troposphere (MOPITT), Geophys. Res. Lett., 31, L23105, doi:10.1029/2004GL021128, 2004.

Khattatov, B. V., Lamarque, J.-F., Lyjak, L. V., Menard, R., Levelt, P., Tie, X., Brasseur, G., and Gille, J. C.: Assimilation of sattelite observations of long-lived chemical species in global chemistry transport models, J. Geophys. Res., 105, 29135-29144, 2000.

Kinnison, D. E., Brasseur, G. P., Walters, S., Gracia, R. R., Marsh, D. R., Sassi, F., Harvey, V. L., Randall, C. E., Emmons, L., Lamarque, J. F., Hess, P., Orlando, J. J., Tie, X. X., Randel, W., Pan, L. L., Gettelman, A., Granier, C., Diehl, T., Niemeier, U., and Simmons, A. J.: Sensitivity of chemical tracers to meteorological parameters in the MOZART3 chemical transport model, J. Geophys. Res, 112, D20302, doi:10.1029/2006JD007879, 2007.

Kleinman, L., Lee, Y.-N., Springston, S. R., Lee, J. H., Nunnermacker, L., Weinstein-Lloyd, J., Zhou, X., and Newman, L.: Peroxy radical concentration and ozone formation rate at a rural site in the Southeastern United States, J. Geophys. Res., 100, 72637274, 1995.

Koelemeijer, R., Stammes, P., Hovenier, J. W., and De Haan, J. F.: A fast method for retrieval of cloud parameters using oxygen a band measurements from the Global Ozone Monitoring Experiment, J. Geophys. Res., 106, 3475-3490, doi:10.1029/2000JD900657, 2001.

Komhyr, W. D., Barnes, R. A., Borthers, G. B., Lathrop, J. A., Kerr, J. B., and Opperman, D. P.: Electrochemical concentration cell ozonesonde performance evaluation during STOIC 1989, J. Geophys. Res., 100, 9231-9244, 1995.

Kopacz, M., Jacob, D. J., Fisher, J. A., Logan, J. A., Zhang, L., Megretskaia, I. A., Yantosca, R. M., Singh, K., Henze, D. K., Burrows, J. P., Buchwitz, M., Khlystova, I., McMillan, W. W., 
Gille, J. C., Edwards, D. P., Eldering, A., Thouret, V., and Nedelec, P.: Global estimates of $\mathrm{CO}$ sources with high resolution by adjoint inversion of multiple satellite datasets (MOPITT, AIRS, SCIAMACHY, TES), Atmos. Chem. Phys., 10, 855-876, doi:10.5194/acp-10-855-2010, 2010.

Krol, M. C. and van Weele, M.: Implications of variations in photodissociation rates for global tropospheric chemistry, Atmos. Environ., 31, 1257-1273, 1997.

Lahoz, W. A., Geer, A. J., Bekki, S., Bormann, N., Ceccherini, S., Elbern, H., Errera, Q., Eskes, H. J., Fonteyn, D., Jackson, D. R., Khattatov, B., Marchand, M., Massart, S., Peuch, V.H., Rharmili, S., Ridolfi, M., Segers, A., Talagrand, O., Thornton, H. E., Vik, A. F., and von Clarmann, T.: the Assimilation of Envisat data (ASSET) project, Atmos. Chem. Phys., 7, 17731796, doi:10.5194/acp-7-1773-2007, 2007.

Lamarque, J.-F., Bond, T. C., Eyring, V., Granier, C., Heil, A., Klimont, Z., Lee, D., Liousse, C., Mieville, A., Owen, B., Schultz, M. G., Shindell, D., Smith, S. J., Stehfest, E., Van Aardenne, J., Cooper, O. R., Kainuma, M., Mahowald, N., McConnell, J. R., Naik, V., Riahi, K., and van Vuuren, D. P.: Historical (1850-2000) gridded anthropogenic and biomass burning emissions of reactive gases and aerosols: methodology and application, Atmos. Chem. Phys., 10, 7017-7039, doi:10.5194/acp10-7017-2010, 2010.

Landgraf, J. and Crutzen, P. J.: An efficient method for online calculations of photolysis and heating rates, J. Atmos. Sci., 55, 863878, 1998.

Levelt, P. F., van den Oord, G. H. J., Dobber, M. R., Mälkki, A., Visser, H., de Vries, J., Stammes, P., Lundell, J. O. V., and Saari, H.: The ozone monitoring instrument, IEEE T. Geosci. Remote, 44, 1093-1101, 2006.

Manney, G. L., Santee, M. L., Rex, M., Livesey, N. J., Pitts, M. C., Veefkind, P., Nash, E. R., Wohltmann, I., Lehmann, R., Froidevaux, L., Poole, L. R., Schoeberl, M. R., Haffner, D. P., Davies, J., Dorokhov, V., Gernandt, H., Johnson, B., Kivi, R., Kyro, E., Larsen, N., Levelt, P. F., Makshtas, A., McElroy, C. T., Nakajima, H., Parrondo, M. C., Tarasick, D. W., von der Gathen, P., Walker, K. A., and Zinoviev, N. S.: Unprecedented Arctic ozone loss in 2011, Nature, 478, 469-475, doi:10.1038/nature10556, 2011.

Marenco, A., Thouret, V., Nédélec, P., Smit, H. G., Helten, M., Kley, D., Karcher, F., Simon, P., Law, K., Pyle, J., Poschmann, G., Von Wrede, R., Hume, C., and Cook, T.: Measurement of ozone and water vapour by Airbus in-service aircraft: The MOZAIC airborne programme, an overview, J. Geophys. Res., 103, 25631-25642, 1998.

Mari, C. H., Cailley, G., Corre, L., Saunois, M., Attié, J. L., Thouret, V., and Stohl, A.: Tracing biomass burning plumes from the Southern Hemisphere during the AMMA 2006 wet season experiment, Atmos. Chem. Phys., 8, 3951-3961, doi:10.5194/acp-8-3951-2008, 2008.

McNally, A. P., Watts, P. D., Smith, J. A., Engelen, R. J., Kelly, G. A., Thépaut, J.-N., and Matricardi, M.: The assimilation of AIRS radiance data at ECMWF, Q. J. Roy. Meteor. Soc., 132, 935-957, 2006.

Millet, D. B., Jacob, D. J., Boersma, K. F., Fu, T.-M., Kurosu, T. P., Chance, K., Heald, C. L., and Guenther, A.: Spatial distribution of isoprene emissions from North America derived from formaldehyde column measurements by the OMI satellite sensor, J. Geophys. Res., 113, D02307, doi:10.1029/2007JD008950,
2008.

Morcrette, J.-J., Boucher, O., Jones, L., Salmond, D., Bechtold, P., Beljaars, A., Benedetti, A., Bonet, A., Kaiser, J. W., Razinger, M., Schulz, M., Serrar, S., Simmons, A. J., Sofiev, M., Suttie, M., Tompkins, A. M., and Untch, A.: Aerosol analysis and forecast in the European centre for medium-range weather forecasts integrated forecast system: forward modeling, J. Geophys. Res., 114, D06206, doi:10.1029/2008JD011235, 2009.

Moss, R. H., Edmonds, J. A., Hibbard, K. A., Manning, M. R., Rose, S. K., van Vuuren, D. P., Carter, T. R., Emori, S., Kainuma, M., Kram, T., Meehl, G. A., Mitchell, J. F., Nakicenovic, N., Riahi, K., Smith, S. J., Stouffer, R. J., Thomson, A. M., Weyant, J. P., and Wilbanks, T. J.: The next generation of scenarios for climate change research and assessment, Nature, 463, 747-756, 2010.

Nedelec, P., Cammas, J.-P., Thouret, V., Athier, G., Cousin, J.-M., Legrand, C., Abonnel, C., Lecoeur, F., Cayez, G., and Marizy, C.: An improved infrared carbon monoxide analyser for routine measurements aboard commercial Airbus aircraft: technical validation and first scientific results of the MOZAIC III programme, Atmos. Chem. Phys., 3, 1551-1564, doi:10.5194/acp-3-15512003, 2003.

Newman, P. A., Oman, L. D., Douglass, A. R., Fleming, E. L., Frith, S. M., Hurwitz, M. M., Kawa, S. R., Jackman, C. H., Krotkov, N. A., Nash, E. R., Nielsen, J. E., Pawson, S., Stolarski, R. S., and Velders, G. J. M.: What would have happened to the ozone layer if chlorofluorocarbons (CFCs) had not been regulated?, Atmos. Chem. Phys., 9, 2113-2128, doi:10.5194/acp-92113-2009, 2009.

Novelli, P. C. and Masarie, K. A.: Atmospheric carbon monoxide dry air mole fractions from the NOAA ESRL carbon cycle cooperative global air sampling network, 1988-2009, version: 2011-10-14, available at: ftp://ftp.cmdl.noaa.gov/ccg/co/ flask/event/ (last access: 29 November 2012), 2010.

Novelli, P. C., Masarie, K. A., Lang, P. M., Hall, B. D., Myers, R. C., and Elkins, J. W.: Reanalysis of tropospheric CO trends: effects of the 1997-1998 wildfires, J. Geophys. Res., 108, 4464, doi:10.1029/2002JD003031, 2003.

Onogi, K., Tsutsui, J., Koide, H., Sakamoto, M., Kobayashi, S., Hatsushika, H., Matsumoto, T., Yamazaki, N., Kamahori, H., Takahashi, K., Kadokura, S.,Wada, K., Kato, K., Oyama, R., Ose, T., Mannoji, N., and Taira, R.: The JRA-25 reanalysis, J. Meteor. Soc. Jpn., 85, 369-432, 2007.

Palmer, P. I., Jacob, D. J., Fiore, A. M., Martin, R. V., Chance, K., and Kurosu, T. P.: Mapping isoprene emissions over North America using formaldehyde column observations from space, J. Geophys. Res., 108, D64180, doi:10.1029/2002JD002153, 2003.

Palmer, P. I., Abbot, D. S., Fu, T.-Z. , Jacob, D. J., Chance, K., Kuruso, T. P. , Guenther, A., Wiedinmyer, C., Stanton, J. C., Pilling, M. J., Pressley, S. N., Lamb, B., and Sumner, A. L.: Quantifying the seasonal and interannual variability of North American isoprene emissions using satellite observations of formaldehyde column, J. Geophys. Res., 111, D12315, doi:10.1029/2005JD006689, 2006.

Parrington, M., Jones, D. B. A., Bowman, K. W., Horowitz, L. W., Thompson, A. M., Tarasick, D. W., an Witte, J. C.: Estimating the summertime tropospheric ozone distribution over North America through assimilation of observations from the Tropospheric Emission Spectrometer, J. Geophys. Res., 113, D18307, 
doi:10.1029/2007JD009341, 2008.

Parrington, M., Jones, D. B. A., Bowman, K. W., Thompson, A. M., Tarasick, D. W., Merrill, J., Oltmans, S. J., Leblanc, T., Witte, J. C., and Millet, D. B.:Impact of the assimilation of ozone from the Tropospheric Emission Spectrometer on surface ozone across North America, Geophys. Res. Lett., 36, L04802, doi:10.1029/2008GL036935, 2009.

Parrish, D. F. and Derber, J. C.: The national meteorological center's spectral statistical-interpolation analysis scheme, Mon. Weather Rev., 120, 1747-1763, 1992.

Pickering, K. E., Thompson, A. M., Wang, Y., Tao, W.-K., McNamara, D. P., Kirchhoff, V. W. J. H., Heikes, B. G., Sachse, G. W., Bradshaw, J. D., Gregory, G. L., and Blake, D. R.: Convective transport of biomass burning emissions over Brazil during TRACE A, J. Geophys. Res., 101, 23993-24012, 1996.

Real, E., Orlandi, E., Law, K. S., Fierli, F., Josset, D., Cairo, F., Schlager, H., Borrmann, S., Kunkel, D., Volk, C. M., McQuaid, J. B., Stewart, D. J., Lee, J., Lewis, A. C., Hopkins, J. R., Ravegnani, F., Ulanovski, A., and Liousse, C.: Crosshemispheric transport of central African biomass burning pollutants: implications for downwind ozone production, Atmos. Chem. Phys., 10, 3027-3046, doi:10.5194/acp-10-3027-2010, 2010.

Riahi, K., Rao, S., Krey, V., Cho, C., Chirkov, V., Fischer, G., Kindermann, G., Nakicenovic, N., and Rafaj, P.: RCP 8.5 - a scenario of comparatively high greenhouse gas emissions, Climatic Change, 109, 33-57, doi:10.1007/s10584-011-0149-y, 2011.

Richter, A. and Burrows, J. P.: Retrieval of tropospheric $\mathrm{NO}_{2}$ from GOME measurements, Adv. Space Res., 29, 1673-1683, 2002.

Richter, A., Burrows, J. P., Nuß, H., Granier, C., and Niemeier, U.: Increase in tropospheric nitrogen dioxide over China observed from space, Nature, 437, 129-132, doi:10.1038/nature04092, 2005.

Rodgers, C. D.: Inverse Methods for Atmospheric Sounding - Theory and Practice, Series on Atmospheric, Oceanic and Planetary Physics, World Scientific Publishing, Singapore, 2000.

Sandu, A. and Chai, T.: Chemical data assimilation - an overview, Atmosphere, 2, 426-463, doi:10.3390/atmos2030426, 2011.

Saunois, M., Emmons, L., Lamarque, J.-F., Tilmes, S., Wespes, C., Thouret, V., and Schultz, M.: Impact of sampling frequency in the analysis of tropospheric ozone observations, Atmos. Chem. Phys., 12, 6757-6773, doi:10.5194/acp-12-6757-2012, 2012.

Solomon, S.: Stratospheric ozone depletion: a review of concepts and history, Rev. Geophys., 37, 275-316, doi:10.1029/1999RG900008, 1999.

Schubert, S. D., Pfaendtner, J., and Rood, R.: An assimilated data set for Earth science applications, B. Am. Meteorol. Soc., 74, 2331-2342, 1993.

Seinfeld, J. H. and Pandis, S. N.: Atmospheric Chemistry and Physics: from Air Pollution to Climate Change, John Wiley, Hoboken, NJ, USA, 1232 pp., 2006.

Semane, N., Peuch, V.-H., Pradier, S., Desroziers, G., El Amraoui, L., Brousseau, P., Massart, S., Chapnik, B., and Peuch, A.: On the extraction of wind information from the assimilation of ozone profiles in Météo-France 4D-Var operational NWP suite, Atmos. Chem. Phys., 9, 4855-4867, doi:10.5194/acp-9-48552009, 2009.

Siddans, R., Reburn, W. J., Kerridge, B. J., and Munro, R.: Height resolved ozone information in the troposphere and lower strato- sphere from GOME, Technical report, British Atmospheric Data Centre (BADC), available at: http://cedadocs.badc.rl.ac.uk/97/ (last access: 29 November 2012), 2007.

Shindell, D. T., Faluvegi, G., Stevenson, D. S., Krol, M. C., Emmons, L. K., Lamarque, J.-F., Pétron, G., Dentener, F. J., Ellingsen, K., Schultz, M. G., Wild, O., Amann, M., Atherton, C. S., Bergmann, D. J., Bey, I., Butler, R., Cofala, J., Collins, W. J., Derwent, R. G., Doherty, R. M., Drevet, J., Eskes, H. J., Fiore, A. M., Gauss, M., Hauglustaine, D. A., Horowitz, L. W., Isaksen, I. S. A., Lawrence, M. G., Montanaro, V., Müller, J.-F., Pitari, G., Prather, M. J., Pyle, J. A., Rast, S., Rodriguez, J. M., Sanderson, M. G., Savage, N. H., Strahan, S. E., Sudo, K., Szopa, S., Unger, N., van Noije, T. P. C., and Zeng, G.: Multi-model simulations of carbon monoxide: comparison with observations and projected near-future changes, J. Geophys. Res., 111, D19306, doi:10.1029/2006JD007100, 2006.

Stavrakou, T., Müller, J.-F., De Smedt, I., Van Roozendael, M., van der Werf, G. R., Giglio, L., and Guenther, A.: Evaluating the performance of pyrogenic and biogenic emission inventories against one decade of space-based formaldehyde columns, Atmos. Chem. Phys., 9, 1037-1060, doi:10.5194/acp-9-1037-2009, 2009.

Stein, O.: Model documentation of the MOZART CTM as implemented in the GEMS system, available at: http://gems.ecmwf. int/do/get/PublicDocuments/1531/1172 (last access: 29 November 2012), 2009.

Stein, O., Flemming, J., Inness, A., Kaiser, J. W., and Schultz, M. G.: Global reactive gases forecasts and reanalysis in the MACC project, J. Integr. Environ. Sci., 9, 57-70, doi:10.1080/1943815X.2012.696545, 2012.

Steinbrecht, W., Shwartz, R., and Claude, H.: New pump correction for the Brewer-Mast ozone sonde: Determination from experiment and instrument intercomparisons, J. Atmos. Ocean. Tech., 15, 144-156, 1998.

Thompson, A. M.: The oxidizing capacity of the Earth's atmosphere: probable past and future changes, Science, 256, $1157-$ $1165,1992$.

Thompson, A. M., Pickering, K., McNamara, D., Schoeberl, M., Hudson, R., Kim, J., Browell, E., Kirchhoff, V., and Nganga, D.: Where did tropospheric ozone over Southern Africa and the tropical Atlantic come from in October 1992? Insights from TOMS, GTE TRACE A, and SAFARI 1992, J. Geophys. Res., 101, 24251-24278, doi:10.1029/96JD01463, 1996.

Tilmes, S., Lamarque, J.-F., Emmons, L. K., Conley, A., Schultz, M. G., Saunois, M., Thouret, V., Thompson, A. M., Oltmans, S. J., Johnson, B., and Tarasick, D.: Technical Note: Ozonesonde climatology between 1995 and 2011: description, evaluation and applications, Atmos. Chem. Phys., 12, 74757497, doi:10.5194/acp-12-7475-2012, 2012.

Torres, O., Chen, Z., Jethva, H., Ahn, C., Freitas, S. R., and Bhartia, P. K.: OMI and MODIS observations of the anomalous 20082009 Southern Hemisphere biomass burning seasons, Atmos. Chem. Phys., 10, 3505-3513, doi:10.5194/acp-10-3505-2010, 2010.

Uppala, S. M., Kallberg, P. W., Simmons, A. J., Andrae, U., da Costa Bechtold, V., Fiorino, M., Gibson, J. K., Haseler, J., Hernandez, A., Kelly, G. A., Li, X., Onogi, K., Saarinen, S., Sokka, N., Allan, R. P., Andersson, E., Arpe, K., Balmaseda, M. A., Beljaars, A. C. M., van de Berg, L., Bid- 
lot, J., Bormann, N., Caires, S., Chevallier, F., Dethof, A., Dragosavac, M., Fisher, M., Fuentes, M., Hagemann, S., Holm, E., Hoskins, B. J., Isaksen, L., Janssen, P. A. E. M., Jenne, R., McNally, A. P., Mahfouf, J.-F., Morcrette, J.J., Rayner, N. A., Saunders, R. W., Simon, P., Sterl, A., Trenberth, K. E., Untch, A., Vasiljevic, D., Viterbo, P., and Woollen, J.: The ERA-40 re-analysis, Q. J. Roy. Meteor. Soc., 131, 2961-3012, 2005.

Valcke, S. and Redler, R.: OASIS4 User Guide (OASIS4_0_2), PRISM-Support Initiative, Technical Report No 4, available at: http://www.prism.enes.org/Publications/index.php (last access: 29 November 2012), 2006.

van der A, R. J., Eskes, H. J., Boersma, K. F., van Noije, T. P. C., Van Roozendael, M., De Smedt, I., Peters, D. H. M. U., and Meijer, E. W.: Trends, seasonal variability and dominant $\mathrm{NO}_{\mathrm{x}}$ source derived from a ten year record of $\mathrm{NO}_{2}$ measured from space, J. Geophys. Res., 113, D04302, doi:10.1029/2007JD009021, 2008. van der A, R. J., Allaart, M. A. F., and Eskes, H. J.: Multi sensor reanalysis of total ozone, Atmos. Chem. Phys., 10, 11277-11294, doi:10.5194/acp-10-11277-2010, 2010.

van der Werf, G. R., Randerson, J. T., Giglio, L., Collatz, G. J., Kasibhatla, P. S., and Arellano Jr., A. F.: Interannual variability in global biomass burning emissions from 1997 to 2004, Atmos. Chem. Phys., 6, 3423-3441, doi:10.5194/acp-6-3423-2006, 2006.

van der Werf, G. R., Randerson, J. T., Giglio, L., Collatz, G. J., Mu, M., Kasibhatla, P. S., Morton, D. C., DeFries, R. S., Jin, Y., and van Leeuwen, T. T.: Global fire emissions and the contribution of deforestation, savanna, forest, agricultural, and peat fires (1997-2009), Atmos. Chem. Phys., 10, 11707-11735, doi:10.5194/acp-10-11707-2010, 2010.

Van Vuuren, D. P., Edmonds, J., Thomson, A., Riahi, K., Kainuma, M., Matsui, T., Hurtt, G. C., Lamarque, J.-F., Meinshausen, M., Smith, S., Granier, C., Rose, S. K., and Hibbard, K. A.: Representative concentration pathways: an overview, Climatic Change, 109, 5-31, doi:10.1007/s10584-0110148-z, 2010.

Wang, P., Stammes, P., van der A, R., Pinardi, G., and van Roozendael, M.: FRESCO+: an improved $\mathrm{O}_{2}$ A-band cloud retrieval algorithm for tropospheric trace gas retrievals, Atmos. Chem. Phys., 8, 6565-6576, doi:10.5194/acp-8-6565-2008, 2008.
Waters, J. W., Froidevaux, L., Harwood, R. S., Jarnot, R. F., Pickett, H. M., Read, W. G., Siegel, P. H., Cofield, R. E., Filipiak, M. J., Flower, D. A., Holden, J. R., Lau, G. K., Livesey, N. J., Manney, G. L., Pumphrey, H. C., Santee, M. L., Wu, D. L., Cuddy, D. T., Lay, R. R., Loo, M. S., Perun, V. S., Schwartz, M. J., Stek, P. C., Thurstans, R. P., Boyles, M. A., Chandra, K. M., Chavez, M. C., Chen, G.-S., Chudasama, B. V., Dodge, R., Fuller, R. A., Girard, M. A., Jiang, J. H., Jiang, Y., Knosp, B. W., LaBelle, R. C., Lam, J. C., Lee, K. A., Miller, D., Oswald, J. E., Patel, N. C., Pukala, D. M., Quintero, O., Scaff, D. M., Van Snyder, W., Tope, M. C., Wagner, P. A., and Walch, M. J.: The Earth Observing System Microwave Limb Sounder (EOS MLS) on the Aura satellite, IEEE Trans. Geosci. Remote, 44, 1075-1092, 2006.

Weber, M., Dikty, S., Burrows, J. P., Garny, H., Dameris, M., Kubin, A., Abalichin, J., and Langematz, U.: The Brewer-Dobson circulation and total ozone from seasonal to decadal time scales, Atmos. Chem. Phys., 11, 11221-11235, doi:10.5194/acp-1111221-2011, 2011.

Wittrock, F.: The Retrieval of Oxygenated Volatile Organic Compounds by Remote Sensing Techniques, $\mathrm{PhD}$ thesis, Univ. of Bremen, Bremen, Germany, 192 pp., 2006.

Wittrock, F., Richter, A., Oetjen, H., Burrows, J. P., Kanakidou, M., Myriokefalitakis, S., Volkamer, R., Beirle, S., Platt, U., and Wagner, T.: Simultaneous global observations of glyoxal and formaldehyde from space, Geophys. Res. Lett., 33, L16804, doi:10.1029/2006GL026310, 2006.

WMO (World Meteorological Organization): Scientific Assessment of Ozone Depletion: 2010, Global Ozone Research and Monitoring Project-Report No. 52, Geneva, Switzerland, 516 pp., 2011.

Zerefos, C. S., Tourpali, K., Eleftheratos, K., Kazadzis, S., Meleti, C., Feister, U., Koskela, T., and Heikkilä, A.: Evidence of a possible turning point in solar UV-B over Canada, Europe and Japan, Atmos. Chem. Phys., 12, 2469-2477, doi:10.5194/acp12-2469-2012, 2012.

Zhang, L., Li, Q. B., Jin, J., Liu, H., Livesey, N., Jiang, J. H., Mao, Y., Chen, D., Luo, M., and Chen, Y.: Impacts of 2006 Indonesian fires and dynamics on tropical upper tropospheric carbon monoxide and ozone, Atmos. Chem. Phys., 11, 10929 10946, doi:10.5194/acp-11-10929-2011, 2011. 